\title{
Gryllacrididae and Tettigoniidae (Insecta, Orthoptera, Ensifera) from Espiritu Santo, Vanuatu
}

\author{
Sylvain HUGEL \\ INCI, UPR 3212 CNRS, Université de Strasbourg, \\ 21 rue René Descartes, F-67084 Strasbourg cedex (France) \\ hugel@neurochem.u-strasbg.fr
}

Hugel S. 2009. - Gryllacrididae and Tettigoniidae (Insecta, Orthoptera, Ensifera) from Espiritu Santo, Vanuatu. Zoosystema 31 (3): 525-576.

KEY WORDS

Insecta, Orthoptera, Gryllacrididae, Tettigoniidae, acoustic communication, Southwestern Pacific, Vanuatu, new species.

\begin{abstract}
In the present article, the Gryllacrididae and Tettigoniidae fauna of Espiritu Santo Island (Vanuatu) is examined. We took advantage of the examination of the material collected during the SANTO 2006 biological survey to give description complements, or to redescribe and/or redefine the concerned species and genera. We recorded 15 species in the island. Five are recorded for the first time in Espiritu Santo and in the Vanuatu archipelago. A 16th species, Conocephalus laetus (Redtenbacher, 1891), recorded by Willemse (1925) has not been collected during the survey. Two new Gryllacrididae Amphibologryllacris butmasi n. sp. and Psilogryllacris tchancha n. sp. are described. Amphibologryllacris macrocera (Walker, 1869) is redescribed. Amphibologryllacris poultoni (Willemse, 1925) is synonymised under $A$. macrocera. The two related genera Amphibologryllacris and Nannogryllacris are redefined. All Xanthogryllacris punctipennis (Walker, 1869) subspecies recognized by Karny are re-established as subspecies under this genus: X. p. punctipennis (Walker, 1869); X. p. confluens (Griffini, 1909); X. p. erimae (Griffini, 1909); X. p. fenestrigera (Griffini, 1913); X. p. gemmicula (Hebard, 1922); X. p. keyica Karny, 1925 (n. comb.); X. p. zatricia Karny, 1928. Epacra cyaneoterminata Karny, 1935 is transferred to Amphibologryllacris. The song and stridulatory file of most Tettigoniidae occurring in Espiritu Santo are described, most of them for the first time: Salomona redtenbacheri Brongniart, 1897; Phaneroptera gracilis Burmeister, 1838; Furnia insularis (Stål, 1876); Ityocephala francoisi Bolívar, 1909; Conocephalus upoluensis (Karny, 1907); C. semivittatus (Walker, 1869); Pseudorhynchus lessonii Serville, 1838; Phisis holdhausi Karny, 1926. The female of Ityocephala francoisi, a Mecopodinae possibly endemic to Espiritu Santo is described for the first time. Salomona redtenbacheri is redescribed and synonymised with S. magnifica Willemse, 1925 and S. haani Brongniart, 1897. Keys to species of Amphibologryllacris, Nannogryllacris, and Furnia are given and characters are illustrated. Keys to Tettigoniidae and Gryllacrididae of Espiritu Santo are given and illustrated.
\end{abstract}




\author{
MOTS CLÉS \\ Insecta, \\ Orthoptera, \\ Gryllacrididae, \\ Tettigoniidae, \\ communication \\ acoustique, \\ Pacifique sud-ouest, \\ Vanuatu,
}

\section{RÉSUMÉ}

Gryllacrididae et Tettigoniidae (Insecta, Orthoptera, Ensifera) d'Espiritu Santo, Vanuatu.

Dans le présent article, la faune des Gryllacrididae et Tettigoniidae de l'île Espiritu Santo (Vanuatu) est examinée. Profitant de l'exploitation du matériel collecté lors de l'expédition SANTO 2006, les espèces et les genres concernés sont redéfinis et/ou redécrits. Nous avons dénombré 15 espèces sur l'île; cinq sont mentionnées pour la première fois à Espiritu Santo et au Vanuatu. Une seizième espèce, Conocephalus laetus (Redtenbacher, 1891), mentionnée par Willemse (1925) n’a pas été collectée durant l'expédition. Deux nouveaux Gryllacrididae Amphibologryllacris butmasi n. sp. et Psilogryllacris tchancha n. sp. sont décrits. Amphibologryllacris macrocera (Walker, 1869) est redécrit. Amphibologryllacris poultoni (Willemse, 1925) est mis en synonymie avec $A$. macrocera. Les deux genres proches Amphibologryllacris et Nannogryllacris sont redéfinis. Toutes les sous-espèces de Xanthogryllacris punctipennis (Walker, 1869) reconnues par Karny sont ré-établies comme sous-espèces sous ce genre: X. p. punctipennis (Walker, 1869); X. p. confluens (Griffini, 1909); $X$. p. erimae (Griffini, 1909); X. p. fenestrigera (Griffini, 1913); X. p. gemmicula (Hebard, 1922); X. p. keyica Karny, 1925 (n. comb.); X. p. zatricia Karny, 1928. Epacra cyaneoterminata Karny, 1935 est transféré dans le genre Amphibologryllacris n. comb. La stridulation et la râpe stridulatoire de la majorité des Tettigoniidae présents à Espiritu Santo sont décrites, la plupart pour la première fois: Salomona redtenbacheri Brongniart, 1897; Phaneroptera gracilis Burmeister, 1838; Furnia insularis (Stål, 1876); Ityocephala francoisi Bolívar, 1909; Conocephalus upoluensis (Karny, 1907); Conocephalus semivittatus (Walker, 1869); Pseudorhynchus lessonii Serville, 1838; Phisis holdhausi Karny, 1926. La femelle de Ityocephala francoisi, un Mecopodinae possiblement endémique de Espiritu Santo est décrite pour la première fois. Salomona redtenbacheri est redécrit et $S$. magnifica Willemse, 1925 et $S$. haani Brongniart, 1897 sont mis en synonymie avec cette espèce. Des clés des espèces d'Amphibologryllacris, Nannogryllacris et Furnia sont données, et les caractères illustrés. Une clé des Tettigoniidae et Gryllacrididae d'Espiritu Santo est proposée et illustrée.

\section{INTRODUCTION}

The first tettigonioid species described from Espiritu Santo island (Vanuatu, formerly New Hebrides) is the Mecopodinae Ityocephala francoisi Bolívar, 1909, although some species occurring in Santo have been described earlier with imprecise locality data (i.e. "New Hebrides"). The Tettigoniidae and Gryllacrididae (Orthoptera, Ensifera) of Espiritu Santo have been shortly reviewed by Willemse (1925) who examined specimens collected by John R. Baker during his journey on the island, and who described as new two species already described from Vanuatu. Since this time, the tettigonioid fauna of the island has not been scrutinized, although the occurrence of some species on the island was reported within monographic works on given genera (Bailey 1979; Pitkin 1980) or tribes (Jin \& Kevan 1992).

Fifteen tettigonioid species have been collected during SANTO 2006 biological survey, a sixteenth species, Conocephalus laetus (Redtenbacher, 1891), recorded by Willemse (1925) was lacking from the collected samples. Two of the collected Gryllacrididae are new to science; three Tettigo- 
niidae are new to Vanuatu: Phaneroptera gracilis Burmeister, 1838; Furnia insularis (Stål, 1876); Platycaedicia sp.

The aim of the present article is to scrutinize the tettigonioid fauna of Espiritu Santo, taking advantage of the material collected during SANTO 2006 biological survey. To achieve this, (1) two new species are described; little known species (2) and genera (3) are redescribed and/or redefined; (4) needed taxonomic changes are performed; (5) description complements of well-defined species are given; (6) the call of most singing species is described; (7) keys to species occurring in Espiritu Santo and of the redescribed genera are given.

1) Two new Gryllacrididae are described: Amphibologryllacris butmasi n. sp. and Psilogryllacris tchancha n. sp.

2) Amphibologryllacris macrocera (Walker, 1869), Furnia insularis (Stål, 1876), Ityocephala francoisi Bolívar, 1909 and Salomona redtenbacheri Brongniart, 1897 are redescribed. The female of I. francoisi is described for the first time.

3) Amphibologryllacris Karny, 1937 and the related genus Nannogryllacris Karny, 1937 are redefined.

4) The following taxonomic changes have been carried out: all Xanthogryllacris punctipennis (Walker, 1869) subspecies recognized by Karny are re-established as subspecies under this genus: Xanthogryllacris erimae (Griffini, 1909) as X. p. erimae (Griffini, 1909); X. fenestrigera (Griffini, 1913) as X.p. fenestrigera (Griffini, 1913); X. zatricia (Karny, 1928 ) as X. p. zatricia (Karny, 1928); Gryllacris keyica Karny, 1925 as X. p. keyica (Karny, 1925) n. comb. Epacra cyaneoterminata (Karny, 1935) is transferred to Amphibologryllacris. Gryllacris poultoni Willemse, 1925 is synonymised under Amphibologryllacris macrocera (Walker, 1869). Salomona haani Brongniart, 1897 and S. magnifica Willemse, 1925 are both synonymised under $S$. redtenbacheri Brongniart, 1897.

5) The stridulatory file of Phaneroptera gracilis Burmeister, 1838; Conocephalus upoluensis (Karny, 1907); C. semivittatus (Walker, 1869); C. oceanicus (Le Guillou, 1841); Pseudorhynchus lessonii Serville, 1838; Phisis holdhausi Karny, 1926; Phisis pseudopallida Jin, 1992 is described and illustrated.
6) The call of I. francoisi, P. gracilis, F. insularis, C. upoluensis, C. semivittatus, P. lessonii, S. redtenbacheri, $P$. holdhausi is described and illustrated.

7) Keys to Espiritu Santo's Tettigonioid species and to Amphibologryllacris, Nannogryllacris and Furnia species are given.

\section{MATERIAL AND METHODS}

\section{MATERIAL AND REPOSITORY}

Extensive fieldwork was made in many localities in Espititu Santo with Laure Desutter-Grandcolas and Tony Robillard, within the "Forests, Mountains, Rivers" theme of SANTO 2006 Biological Survey. For a narrative of the expedition, see Bouchet et al. (2008), for a review of the geography and natural history of Santo refer to Bouchet et al. (in press). Most specimens were collected by sight, by night and day, in order to observe their precise habitat and type of activity. Specimens collected are deposited in MNHN collections.

\section{GRYLLACRIDIDAE APPENDICES CERCIFERAE}

(FIG. 3A, C, F, G)

The homology of the different appendices on male Gryllacrididae terminalia remains unclear; the terminology to describe them is therefore not satisfactory. Griffini's "appendices cerciferae" are sclerified plates considered by Karny (1937) as being linked ("eingelenkt") with the cerci, and by Kaltenbach (1968) as being articulated with T IX (see abbreviations section). Both definitions are not mutually exclusive, and would then well correspond to what I consider here under this name.

The localisation of these sclerified plates in the one hand enclaved within T IX lateral and posterior lobes, and on the other hand dorsally to T XI (paraprocts, where the cerci are laterally articulated) suggests that these plates are reduced and modified T X sclerites.

Kaltenbach (1968) interpreted N. niaoulii terminalia appendices as not being homologous to the appendices cerciferae as a direct articulation of the tergites was lacking. This might be a misinterpretation due to dry specimen preservation (preventing 
the observation of the sclerites limits). Moreover "articulation" only means that appendices cerciferae are relatively closely linked with the neighbouring sclerites by soft membrane.

\section{PHISIDINI MALE GENITALIA}

Phisidini male genitalia have been dissected in softened specimens by cutting the membranes between the paraprocts and the subgenital plate; they have been observed after cleaning with cold $\mathrm{KOH}$ and kept in glycerine vials pinned under studied specimens.

\section{TERMINOLOGY}

Face of Salomona terminology follows Willemse (1925). General shapes terminology follows Dirsh (1965).

\section{Acoustic terminology}

Acoustic terminology is adapted from Ragge \& Reynolds (1998): syllables are the sound produced supposedly by one to-and-fro movement of the stridulatory apparatus; syllables are organized in echemes, echemes on echeme-sequences; train: used for rapid repetitions of ungrouped but clearly individualised syllables; buzz: used for a long uniform sequence of cohesive syllables repeated at a high rate. The first harmonic (fundamental) is the only carrier frequency given in the text as the recording device used in the field usually does not allow to define whether it corresponds to the dominant frequency (numerous Eneopterinae specimens are covering the ultrasound frequencies range in most of the visited localities).

\section{Tegminal veins terminology}

For convenience purpose, Karny's (1937) terminology and interpretation of Gryllacrididae veination are used in the present article (except for the postcubital veins called anals). This interpretation is nevertheless questionable as what he considers as precostals are all the veins anterior to the first marginal one (which he considers the costal); however, the precostal veins are considered as absent in all extent insects and costal veins are often but not necessarly marginal (Lawrence et al. 1991). Moreover, Karny's precostal veins are emerging from a distinct plate (Fig. 9B) that can be interpreted as the humeral plate (Desutter-Grandcolas 2003) suggesting that these are costal veins. In Karny's work, the veins posterior to the claval fold are called postcubital veins; these are called anals in the present work.

Tettigoniidae male tegminal veins are named according to homology statements achieved by Desutter-Grandcolas (2003).

\section{ACOUSTIC ANALYSES}

Most of the sound recordings have been performed directly on the field; few were also performed on field laboratories. Sounds were acquired with a Pettersson D230 bat detector (heterodyne and 10 times frequency division) connected to a Sony HDR HC1E video camera ( $48 \mathrm{kHz}$ sampling frequency), allowing to image the recorded specimens in the infrared mode. Acoustic signals were analysed with Clampfit 9.2.1.8 (Axon Instruments). Mean values are given \pm standard deviation. The dominant frequency peak was determined on the field (heterodyne mode) and/or post hoc using the frequency division channel. All the recording files have been deposited in the sound library of the Muséum national d'Histoire naturelle, Paris and in the author acoustic database.

\section{SCAN ELECTRON MICROSCOPY}

Dry specimens were directly imaged, without metallization, with a scan electron microscope Philips XL-30 ESEM in environmental mode, with a 1-2 Torr vacuum, and an acceleration of $20-25 \mathrm{MeV}$.

\section{ABBREVIATIONS}

Descriptions
A C $\quad$ appendice cercifera;
FW $\quad$ forewing;
HW $\quad$ hind wing.
Tegminal veins:
$\begin{array}{ll}\text { R, radial vein; M, media; Cu, cubitus; A, } \\ \text { anal vein. } \\ \text { Tergites: } & \text { T + tergite number (e.g., T I, first tergite). } \\ \text { d V } & \text { ovipositor dorsal valves; } \\ \text { FI } & \text { fore femur; } \\ \text { FII } & \text { mid femur; } \\ \text { FIII } & \text { hind femur; } \\ \text { ms s } & \text { mesosternum; }\end{array}$




$\begin{array}{ll}\text { mt } s & \text { metasternum; } \\ \text { SGP } & \text { subgenital plate; } \\ \text { TI } & \text { fore tibia; } \\ \text { TII } & \text { mid tibia; } \\ \text { TIII } & \text { hind tibia; } \\ \text { v V } & \text { ovipositor ventral valves. }\end{array}$

\section{Institutions}

BMNH Natural History Museum, London;

BPBM Bernice P. Bishop Museum, Honolulu;

HNHM Hungarian Natural History Museum, Budapest;

MBBJ Museum Zoologicum Bogoriense, Bogor, Indonesia;

MLUH Martin Luther Universität, Halle;

MNHN Muséum national d'Histoire naturelle, Paris;

MNM Museo Nacional de Ciencias Naturales, Madrid;

NHMB Naturhistorisches Museum, Basel;

NHRS Naturhistoriska Riksmuseet, Stockholm;

NHW Naturhistorisches Museum Wien, Vienna;

UMO Oxford University Museum of Natural History, Oxford;

ZMUH Zoologisches Museum der Universität Hamburg.

\section{SYSTEMATICS}

List of Gryllacrididae and Tettigoniidae addressed in the present article (species from Espiritu Santo are underlined, data provided are in square brackets):

Gryllacrididae Blanchard, 1845

Xanthogryllacris Karny, 1937

X. punctipennis (Walker, 1869)

Amphibologryllacris Karny, 1937 [diagnosis relatively to Nannogryllacris Karny, 1937; key to species of both genera]

A. cyaneoterminata (Karny, 1935) n. comb. [described under Epacra Brunner von Wattenwyl, 1888, herein transferred to Amphibologryllacris]
A. macrocera (Walker, 1869) [redescription; G. poultoni Willemse, 1925 n. syn.]

A. butmasi n. sp. [description]

Nannogryllacris Karny, 1937

Psilogryllacris Karny, 1937

P. tchancha n. sp. [description]

Tettigoniidae Krauss, 1902

Mecopodinae Walker, 1871

Ityocephala Redtenbacher, 1892

I. nigrostrigata (Walker, 1871)

I. francoisi Bolívar, 1909 [redescription, first description of the female, song]

Phaneropterinae Burmeister, 1838

Phaneroptera Serville, 1831

P. gracilis Burmeister, 1838 [stridulatory file, song]

Platycaedicia Hebard, 1922

Platycaedicia sp.

Furnia Stål, 1876 [key to species]

F. insularis (Stål, 1876) [redescription]

Conocephalinae Burmeister, 1838

Conocephalini Burmeister, 1838

Conocephalus Thunberg, 1815

C. upoluensis (Karny, 1907) [stridulatory file, song]

C. semivittatus (Walker, 1869)

C. semivittatus vittatus (Redtenbacher, 1891) [stridulatory file, song]

C. oceanicus (Le Guillou, 1841) [stridulatory file]

C. laetus (Redtenbacher, 1891)

Copiphorini Karny, 1912

Pseudorhynchus Serville, 1838

P. Lessonii Serville, 1838 [stridulatory file, song]

Agraeciini Bruner, 1915

Salomona Blanchard, 1853

S. redtenbacheri Brongniart, 1897 [redescription, song, S. haani Brongniart, 1897 n. syn.; S. magnifica Willemse, 1925 n. syn.]

Listroscelidinae Redtenbacher, 1891

Phisidini Jin, 1987

Phisis

P. holdhausi Karny, 1926 [stridulatory file, song] P. pseudopallida ]in, 1992 [stridulatory file]

Key to adult Tettigoniddae Krauss, 1902 and Gryllacrididae Blanchard, 1845

All species are winged. FROM ESPIRITU SANTO

1. TI with tympana; $0^{\text {* }}$ with stridulum; \% SGP preceding tergite unmodified

- TI without tympana; ơ without stridulum; O SGP preceding tergite with a protrusion (Fig. 2A, B) Gryllacrididae, 2 
2. Large, FW length $>25 \mathrm{~mm}$; HW orange with distinct black patterns around transverse veinlets Xanthogryllacris punctipennis

- Medium to small, FW length < $21 \mathrm{~mm}$; HW hyaline, or with weakly smoked cells and hyaline around transverse veinlets 3

3. TI and TII proximal subapical spurs distinctly shorter than tibia width (Fig. 8B, C); head rounded (Fig. 8A); FIII thickened (Fig. 8F) Psilogryllacris tchancha n. sp.

- TI and TII proximal subapical spurs distinctly longer than tibia width; head more elongated (Fig. 2E, F); FIII more slender (Fig. 2C, D) Amphibologryllacris, 4

4. FW with 4 or 5 precostal veins (Fig. 4B); FIII length > $12 \mathrm{~mm}$; ovipositor length $>11.5 \mathrm{~mm}$; pronotum discus anterior margin usually not darkened ... Amphibologryllacris macrocera

- FW with 2 or 3 precostal veins (Fig. 4A); FIII length $<12 \mathrm{~mm}$; ovipositor length $<10.5 \mathrm{~mm}$; pronotum discus anterior margin always darkened ... Amphibologryllacris butmasi n. sp.

5. TI and FI with long predatory spurs; slender Phisis, 6

- TI and FI without long predatory spurs; slender or not .... .. 7

6. FI with 5 outer and 4 inner spurs; male epiproct posterior margin rounded with a median emargination (Fig. 21A) Phisis holdhausi

- FI with 6 outer and 5 inner spurs; male epiproct posterior margin truncated (Fig. 21B) Phisis pseudopallida

7. Prosternum without spines; ovipositor short, $<8 \mathrm{~mm}$ Phaneropterinae, 8

- Prosternum with spines; ovipositor longer, $>8 \mathrm{~mm}$ 10

8. Pronotum with distinct lateral carinae; FW width $>8.5 \mathrm{~mm}$; ovipositor length $<3 \mathrm{~mm}$ Platycaedicia sp.

— Pronotum without lateral carinae; FW width $<7.5 \mathrm{~mm}$; ovipositor length $>4 \mathrm{~mm} \ldots 9$

9. Hind knee about reaching the FW posterior margin

- Hind knee not exceeding the FW distal third Phaneroptera gracilis

10. Fastigium broad, not projecting, truncated in dorsal view, with an apical longitudinal sulcus (Fig. 10B); FW width $>10 \mathrm{~mm}$ Ityocephala francoisi

- Fastigium broad or not, projecting or not, not truncated, without apical sulcus; FW width $<10 \mathrm{~mm}$ Conocephalinae, 11

11. Head wide, maximal width $>9 \mathrm{~mm}$ (Fig. 18A-D); with black pattern around the eyes Salomona redtenbacheri

- Head less wide, maximal width $<6 \mathrm{~mm}$; without black pattern around the eyes ...... 12

12. Fastigium wide, projecting as a cone; FW length $>30 \mathrm{~mm}$; HW not exceeding the FW Pseudorhynchus lessonii

- Fastigium narrow, moderately projecting; FW length $<25 \mathrm{~mm}$; brachypterous or HW exceeding the FW Conocephalus, 13

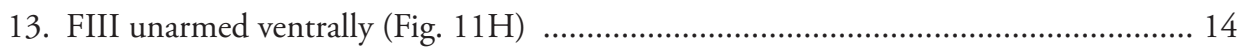

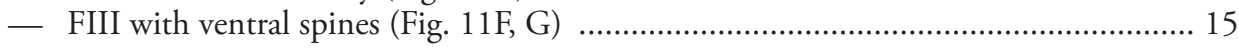

14. FW with at least some markings Conocephalus upoluensis

- FW unicolorous (without markings), not reduced Conocephalus laetus

15. FW with at least some markings, reduced Conocephalus semivittatus vittatus

- FW unicolorous Conocephalus oceanicus 
Family GRYLLACRIDIDAE Blanchard, 1845

Gryllacrididae Blanchard, 1845: 238 [as Gryllacrites].

Genus Xanthogryllacris Karny, 1937

\section{Xanthogryllacris punctipennis (Walker, 1869)}

Gryllacris punctipennis Walker, 1869: 172.

Xanthogryllacris punctipennis - Karny 1937: 157.

Type Material. - [Indonesia, Maluku, Pulau Batjan] Batchian, collection Saunders, ơ holotype (BMNH). Not examined.

Type locality. - Indonesia, Maluku, Pulau Batjan.

HABITAT AND LIFE HISTORY TRAITS. - Specimens have been observed foraging by night hours on various plants species (Hibiscus sp., Pandanus sp., etc.) at 1-3 m height (pers. obs.). All three localities where the species has been observed are near the shore (elevation $<5 \mathrm{~m}$ ).

\section{REMARKS}

Karny (1937) considered seven $X$. punctipennis subspecies as valid: $X$. p. punctipennis (Walker, 1869); X. p. confluens (Griffini, 1909); X. p. erimae (Griffini, 1909); X. p. fenestrigera (Griffini, 1913); X.p. gemmicula (Hebard, 1922); X.p. keyica (Karny, 1925); X. p. zatricia (Karny, 1928). In Orthoptera Species Files, Otte (2000) kept three of the seven subspecies (X.p. confluens, X. p. punctipennis, X. $p$. zatricia) and implicitly raised three other subspecies to the species level ( $X . p$. erimae, $X . p$. fenestrigera, $X . p$. gemmicula), and transferred $X . p$. keyica to the genus Gryllacris Serville, 1831 (this latter subspecies is explicitly raised to the species level under Gryllacris). Whereas such changes are usually explicitly listed in Otte's work bibliographic list as " 2000 Otte, this work", the preceding ones were not.

It is clear that a comprehensive study is required to define whether the subspecies recognized by Karny $(1925,1928,1937)$ are really belonging to a single polymorphous species, particularly the so-called sympatric forms (that are - if really sympatric either varieties or distinct species) and/or these with characters known to be variable in gryllacridids which might well correspond to varieties.
Nevertheless, at this stage, as such comprehensive study is lacking, I prefer to keep all these seven subspecies under one single species as valid subspecies of X. punctipennis, under the genus Xanthogryllacris. Xanthogryllacris punctipennis keyica cannot be transferred to Gryllacris without a deep redefinition of both genera. Although superficially similar in the wing coloration and venation, both genera are clearly distinguished (apart from size and colour differences): in Xanthogryllacris males, T VIII is unmodified, T IX is bent downwards, the styli are short and rounded, in females the sternite preceding the SGP (VII) bears a protrusion; in Gryllacris males, T VIII is elongated compared to the preceding tergites, T IX is strongly modified (pistil-shaped and/or with two dorsal blunt protrusions), styli are long and sharp, in females the sternite preceding the SGP is unmodified (Brunner von Wattenwyl 1888; Karny 1937). Therefore Gryllacris keyica is retransferred to Xanthogryllacris, as a subspecies of $X$. punctipennis.

Xanthogryllacris punctipennis (as considered in the present work as containing seven subspecies) is one of the most widespread gryllacridid species with a distribution ranging from New Guinea to Maluku, Borneo, Key island, North of Australia (Karny 1930a, 1937; Tepper 1892). This species has been collected in Espiritu Santo by J. R. Baker (Willemse 1925). With dark - although not black - face and the characteristics of the black patterns on HW, the specimens collected in Santo are rather similar to $X$. punctipennis keyica Karny, 1925. Nevertheless, the face, the scapus and the fore knees are paler than Karny's illustrations of the subspecies (Karny 1925).

\section{Xanthogryllacris punctipennus erimae (Griffini, 1909)}

Gryllacris punctipennis var. erimae Griffini, 1909: 314. — Karny 1925: 62.

Xanthogryllacris punctipennus erimae - Karny 1937: 157. Xanthogryllacris erimae - Otte 2000: 32.

Type Material. - Papuasia, New Guinea, Erima, Astrolabe Bay, on holotype (HNHM). Not examined.

TyPe LOCAlity. - Tropical Asia, Papuasia, New Guinea, Erima, Astrolabe Bay. 


\section{Xanthogryllacris punctipennis fenestrigera}

(Griffini, 1913)

Gryllacris punctipennis var. fenestrigera Griffini, 1913: 289.

Xanthogryllacris punctipennis fenestrigera - Karny 1937: 157.

Xanthogryllacris fenestrigera - Otte 2000: 32.

TYPe MATERiAL. - Maluku, Banda Island, ơ holotype (HNHM). Not examined.

Type Locality. - Tropical Asia, Malesia, Maluku, Banda Neira.

\section{Xanthogryllacris punctipennis gemmicula} (Hebard, 1922)

Gryllacris punctipennis gemmicula Hebard, 1922: 279.

Xanthogryllacris punctipennis gemmicula - Karny 1937: 157.

Xanthogryllacris gemmicula - Otte 2000: 32.

Type Material. - Obi Island, Moluccas, Hebard Collection no. 850. $0^{\pi}$ holotype (HNHM). Not examined.

Type Locality. - Tropical Asia, Malesia, Maluku, Obi Island.

\section{Xanthogryllacris punctipennis keyica}

(Karny, 1925)

Gryllacris punctipennis keyica Karny, 1925: 63.

Xanthogryllacris punctipennis keyica - Karny 1937: 157.

Gryllacris keyica - Otte 2000: 18.

TYPe MATERIAL. - [Indonesia, Maluku], Key- [= Kai] isl., o holotype (MBBJ). Not examined.

Type LOCALITY. - Indonesia, Maluku, Kai islands [N.B.: not Key island from Tasmania's Long Island group (Australia)].

\section{Xanthogryllacris punctipennis punctipennis}

(Walker, 1869)

Gryllacris punctipennis Walker, 1869: 172. - Kirby 1906: 145
Gryllacris punctipennis punctipennis-Griffini 1909: 313; 1911: 113. — Karny 1925: 52.

Xanthogryllacris punctipennis punctipennis - Karny 1937 : 157.

Type Material and TYPe LOCAlity. - As for $X$. punctipennis.

\section{Xanthogryllacris punctipennis confluens} (Griffini, 1909)

Gryllacris punctipennis confluens Griffini, 1909: 314.

Xanthogryllacris punctipennis confluens - Karny 1937: 57.

Type Material. - Asia-Tropical, Papuasia, New Guinea, Friedrich Wilhelmshafen, $\odot$ holotype (HNHM). Not examined.

Type LoCality. - Asia-Tropical, Papuasia, New Guinea, Friedrich Wilhelmshafen.

\section{Xanthogryllacris punctipennis zatricia} (Karny, 1928)

Gryllacris punctipennis zatricia Karny, 1928: 250.

Xanthogryllacris punctipennis zatricia - Karny 1937: 57.

Type Material. - Tropical Asia, Papuasia, New Guinea, o holotype (HNHM). Not examined.

Type locality. - Tropical Asia, Papuasia, New Guinea.

MAterial eXAmined. - Vanuatu. (1 $0^{7}, 6 \% q, 1$ juv.), Province Sanma, Espiritu Santo Is., Peavot, littoral, 1459'27'S, $166^{\circ} 47^{\prime} 37^{\prime \prime} \mathrm{E}, 0-5 \mathrm{~m}$ alt., végétation arbustive en arrière de la plage, nuit, sur haies d'Hibiscus, Exped. SANTO 2006, 24.X.2006, coll. S. Hugel, 1 ㅇ (SH-001), 1 juv (SH-002) (MNHN-ENSIF2153, 2154).

Matantas, Big Bay, Vatthé Conservation area, $15^{\circ} 20^{\prime} \mathrm{S}$, $166^{\circ} 95^{\prime} \mathrm{E}, 0-5 \mathrm{~m}$ alt., nuit, sur arbuste en sous-bois, Exped. SANTO 2006, 26.X.2006, coll. S. Hugel, 1 \% (SH-003) (MNHN-ENSIF2155).

Luganville, site du CTRAV, $15^{\circ} 27^{\prime} 00^{\prime \prime}$ S, 167²'26”E, $2 \mathrm{~m}$ alt., forêt côtière sur sable, nuit, sur Pandanus et arbuste en sous-bois, Exped. SANTO 2006, 28.X.2006, coll. S. Hugel, 2 우 (SH-004, SH-005) (MNHNENSIF2156, 2157). - Idem, nuit, sur arbustes en sous-bois, 29.X.2006, 1 o" (SH-006), 2 우 (SH-007, SH-008) (MNHN-ENSIF2158-2160). 


\section{Genus Amphibologryllacris Karny, 1937}

Amphibologryllacris Karny, 1937: 134.

TYPE SPECIES. - Gryllacris dubia Le Guillou, 1841.

Distribution. — see Karny (1930a).

DiAGNOSIS. - Nannogryllacris and Amphibologryllacris are distinguished from all other gryllacridid genera by the following characters: Head: not particularly wide; frons smooth or indistinctly punctuated; frons/genae limit not forming a sharp prominent carina. Pronotum: not with a deep furrow (unlike in Epacra). Wings: FW and HW well developed; transverse veinlets neither darkened nor lined with dark. FW only one and half as long as TIII. FW M either free on FW base (Fig. 1), or emerging from Rs; M simple or with one bifurcation; Cu usually furcating on 3 to 4 branches, in this case at least $5 \mathrm{~A}$ are following, the last two often with a common root. HW transparent or light smoked, without strikingly black transverse veinlets; Rs + $\mathrm{M}$ with simple common root emerging from $\mathrm{R}$, or basally with a common root with Cu. Legs: TI and TII with 2 rows of 4 well-developed ventral subapical spurs (in addition to the 2 apical spurs); TII dorsally unarmed or with at most 1 dorsal posterior apical spur; FIII neither particularly long nor slender (Fig. 2C, D; elongated in Epacra); TIII unmodified, not with 1 or 2 long spear-shaped spines (i.e. unmovable) on the inner margin. External genitalia: neither male anal segment nor subgenitalis stretched backwards into a hull shape; male cerci usually not much longer than styli; on T IX, neither blunt nor spiny protrusion; appendices cerciferae at least developed in some species; male subgenital plate without a small protrusion on the middle, between the styli; ovipositor well sclerotized, not rolled in dead specimens; females of most species with SGP preceding sternite usually modified (bulging and/or with protrusion(s), such modifications are lacking in Epacra).

In addition to the above-mentioned character combination, Amphibologryllacris is characterized by the following. Size: body length: 15.5-31 mm; FIII: 10.2-16; FW: 16-25 mm. Colour: light brown, some species and/or specimens with black elements (face, occiput, pronotum, knees, legs, abdominal tergites/sternites); FW veins colour usually strikingly light compared to the darker FW cells. Prosternum unarmed; mesosternum lateral lobes forming distinct ventral spines pointing ventrally; metasternum lateral lobes with smaller spines pointing ventrally backwards (Fig. 1). Cerci not reduced, longer than styli.

\section{AMPHIBOLOGRYLLACRIS POSITION RELATIVELY \\ TO NANNOGRYLLACRIS AND EPACRA}

Until now, only two gryllacridid genera were considered as bearing spiny lobes on mesosternum and metasternum: Epacra and Afroepacra Griffini, 1911. On museum specimens, this obvious character is often hidden by the legs, and has therefore not been seen by previous authors (suggesting that other described genera might share this character too). Usually, most gryllacridid genera are badly defined by very few (often one) discrete characters supposedly derived, and this has not been cladistically tested. In spite of the character paucity, Amphibologryllacris, Nannogryllacris and Epacra appear as clearly distinct genera, but in the absence of a comprehensive cladistic analysis of the subfamily, stating affinities between genera would be too speculative.

\section{Key tO ADULT AMPHIBOLOGRYLLACRIS KARNY, 1937 SPECIES}

1. All tibiae darkened on the middle; median ocellus small, testaceous, FW almost hyaline (Le Guillou's description [1841] is evasive, and the type seems lost [Karny 1932], obliging to deal with this poorly known species at the beginning of the key) ............. A. oceanica

- Tibia darkened or not but never all tibiae darkened in the middle; median ocellus wide (as wide as the fastigium), medium (half as wide as the fastigium) or absent, FW with hyaline and/or smoked cells

2. FW (Fig. 4A, B): M simple (unfurcated), not fused with adjacent veins; Cu bifurcated twice (3 terminal Cu veins); when known, male SGP with a distinct emargination (Fig. 2G, H), males unknown in A. dubia and A. cyaneoterminata; female SGP preceding sternite with or without long projection 3

- FW M fused with R and/or Cu (Fig. 4C, D); male SGP without well distinct emargination (Fig. 5A); female SGP preceding sternite without long projection ............................. 6

3. Tibiae without black; female SGP preceding sternite with a long process with a ladle-shaped apex; ovipositor slightly shorter than FIII .... 
- Tibiae black on the middle or black on the fore and mid knees; female SGP preceding sternite bulging on the lateral posterior margin (Fig. 5E), without long process; ovipositor as long as or longer than FIII 5

4. FW with 4 or 5 precostal veins (Fig. $4 \mathrm{~B}$ ); FIII length > $12 \mathrm{~mm}$; ovipositor length > $11.5 \mathrm{~mm}$; pronotum discus anterior margin usually not darkened A. macrocera

- FW with 2 or 3 precostal veins (Fig. 4A); FIII length $<12 \mathrm{~mm}$; ovipositor length $<10.5 \mathrm{~mm}$; pronotum discus anterior margin always darkened ............................ A. butmasi n. sp.

5. TI black on the middle; median ocellus large, yellow; ovipositor slightly longer than FIII (Fig. 5E, F); FW cells not smoked; body length $20.5-21 \mathrm{~mm}$.......................... A. dubia

- All knees with black (on both tibia and femora); median ocellus inconspicuous; FW cells smoked; body length $29 \mathrm{~mm}$ A. cyaneoterminata n. comb.

6. FW: $\mathrm{M}$ fused with $\mathrm{R}$ after base, emerging from $\mathrm{R}$ after the first third of $\mathrm{FW}$ length, contacting $\mathrm{Cu}$ near FW mid length (Fig. 4C); median ocellus medium, orange

A. ferruginea

- FW: M not contacting R; Cu fused with $\mathrm{M}$ shortly after base and emerging from it at FW first third (Fig. 4D); median ocellus wide, yellowish A. painei

\section{Amphibologryllacris cyaneoterminata (Karny, 1935) n. comb.}

Epacra cyaneo-terminata Karny, 1935: 32; 1937: 74.

TYPE MATERIAL. - [Australia], Rockhampton, M[useum]. G[odeffroy] 4590 [manuscript]; №4590, Gryllacris cyano terminate Br Rockh. [manuscript]; cyano-termi-nata Brun. [manuscript]; Epacra cyaneo-terminata Type !! det. Karny.[manuscript]; Holotype[red label printed]; DORSA EGepacyaHTF, o holotype (ZMUH). High quality pictures examined.

Type LOCALITY. - Australasia, Australia, Queensland, Rockhampton.

\section{REMARKS}

With its $25 \mathrm{~mm}$ short FW (34-44 mm in Epacra) reaching the end of the abdomen (exceeding the abdomen in Epacra), less than twice as long as the FIII (FW more than twice as long as the FIII in Epacra), having strikingly light veins compared to the darker FW cells (FW are transparent in Epacra); with the penultimate female sternite modified with two lateral bulging (this sternite is unmodified in Epacra), this species should at this stage be considered as belonging to Amphibologryllacris. Since the species description, Karny (1935 and also 1937) had doubts on the generic assignation of this taxon, but at this time, in the Indo Australian area, only
Epacra was known as having modified meso- and metasternum.

Amphibologryllacris macrocera (Walker, 1869) (Figs 1A; 2B, D, F, H; 3C-E; 4B)

Gryllacris macrocera Walker, 1869: 186.

Amphibologryllacris macrocera - Karny 1937: 135.

Gryllacris poultoni Willemse, 1925: 518.

Amphibologryllacris macrocera var. poultoni - Karny 1937: 135 .

Amphibologryllacris poultoni-Otte 2000: 3.

Type Material. — [Vanuatu] New Heb[rides]; Type [green label]; macrocera [ms]; E. coll (1830-73) W.W. Saunders. Purchased and pres. '73 by Mrs. F.W. Hope; Gryllacris macrocera Walker M Typus!; TYPE ORTH: 785 Gryllacris macrocera Walker. ${ }^{7}$ holotype (UMO). Examined.

Type locality. - Southwestern Pacific, Vanuatu.

Other material eXAmined. - Type material of $G$. poultoni: Jan 12.1923., [Vanuatu] N.Hebrides, 0-100 ft $3 \mathrm{~m}$, E. of Esp. Santo I. Elephant I., open forest dd J. R. Backer, Percy Sladen Mem. Fd.1923; [Espiritu] Santo; 12 Jun 1923; TYPE F, Willemse. Gryllacris poultoni. Tr.Ent. Soc.L., 1925,p.518.; Gryllacris Poultoni type nov.sp. F, 
TABLE 1. - Measurements of Amphibologryllacris macrocera (Walker, 1869), including the female holotype of $A$. poultoni (Willemse, 1925). Abbreviations: see text. Notes: 1, frontal view, base of scapus level; 2, 4, depends on the preservation; $\mathbf{3}$, depends on the wing arching.

\begin{tabular}{|c|c|c|c|c|c|c|c|c|c|c|c|c|c|c|c|c|c|c|}
\hline & \multirow{2}{*}{$\begin{array}{c}\text { Bd } \\
\mathrm{L}\end{array}$} & \multirow{2}{*}{$\begin{array}{c}\text { Hd } \\
\mathbf{W} \\
\text { max. }\end{array}$} & \multirow{2}{*}{$\begin{array}{c}\mathrm{FFr}^{1} \\
\mathrm{~W}\end{array}$} & \multicolumn{2}{|c|}{ Prn } & \multicolumn{2}{|c|}{ FW } & \multirow{2}{*}{$\begin{array}{l}\text { TI } \\
\text { L }\end{array}$} & \multirow{2}{*}{$\begin{array}{l}\text { TII } \\
\mathbf{L}\end{array}$} & \multirow{2}{*}{$\begin{array}{c}\text { TIII } \\
\mathbf{L}\end{array}$} & \multirow{2}{*}{$\begin{array}{l}\text { FI } \\
\text { L }\end{array}$} & \multirow{2}{*}{$\begin{array}{c}\text { FII } \\
\text { L }\end{array}$} & \multicolumn{2}{|c|}{ FIII } & \multicolumn{2}{|c|}{ SGP } & \multirow{2}{*}{$\begin{array}{c}\text { Sty } \\
\text { L }\end{array}$} & \multirow{2}{*}{$\begin{array}{c}\text { Ovs } \\
\text { L }\end{array}$} \\
\hline & & & & $\mathbf{L}$ & $\begin{array}{c}\mathbf{W}^{2} \\
\text { max. }\end{array}$ & $\mathbf{L}$ & $\begin{array}{c}\text { W3 }^{3} \\
\text { mid. }\end{array}$ & & & & & & $\mathbf{L}$ & $\begin{array}{c}\mathbf{W} \\
\text { max. }\end{array}$ & $\begin{array}{c}\mathbf{L} \\
\max .\end{array}$ & $\begin{array}{c}\text { W4 } \\
\text { base }\end{array}$ & & \\
\hline on holotype & 19.3 & 4.3 & 1.6 & 5.2 & 5.5 & 17.5 & 7.9 & 7.3 & 7.7 & 11.8 & 6.7 & 6.8 & 12.2 & 3.5 & 1.7 & 2.2 & 1.2 & - \\
\hline I. poultoni & 25.4 & 4.7 & 1.6 & 5.5 & 6.2 & 18.1 & 7.3 & 7.5 & 7.8 & 13.0 & 6.8 & 6.8 & 12.7 & 3.9 & 2.3 & 2.9 & - & 11.8 \\
\hline $\begin{array}{c}\sigma^{\pi} \mathrm{n}=10 \\
\min . \\
\max .\end{array}$ & $\begin{array}{l}26.0 \\
19.3 \\
30.9\end{array}$ & $\begin{array}{l}4.8 \\
4.3 \\
5.3\end{array}$ & $\begin{array}{l}1.6 \\
1.5 \\
1.7\end{array}$ & $\begin{array}{l}5.6 \\
5.2 \\
5.9\end{array}$ & $\begin{array}{l}6.0 \\
5.3 \\
6.5\end{array}$ & $\begin{array}{l}19.4 \\
17.5 \\
20.7\end{array}$ & $\begin{array}{l}8.0 \\
7.4 \\
8.7\end{array}$ & $\begin{array}{l}7.6 \\
7.3 \\
8.1\end{array}$ & $\begin{array}{l}7.9 \\
7.5 \\
8.4\end{array}$ & $\begin{array}{l}12.7 \\
11.8 \\
13.4\end{array}$ & $\begin{array}{l}7.1 \\
6.7 \\
7.3\end{array}$ & $\begin{array}{l}7.2 \\
6.8 \\
7.6\end{array}$ & $\begin{array}{l}13.2 \\
12.2 \\
14.0\end{array}$ & $\begin{array}{l}4.0 \\
3.5 \\
4.3\end{array}$ & $\begin{array}{l}1.8 \\
1.7 \\
2.0\end{array}$ & $\begin{array}{l}3.0 \\
2.2 \\
3.4\end{array}$ & $\begin{array}{l}1.3 \\
1.2 \\
1.5\end{array}$ & $\begin{array}{l}- \\
- \\
-\end{array}$ \\
\hline $\begin{array}{c}\mathrm{n}=9 \\
\min . \\
\max .\end{array}$ & $\begin{array}{l}25.4 \\
21.0 \\
29.0\end{array}$ & $\begin{array}{l}4.9 \\
4.7 \\
5.3\end{array}$ & $\begin{array}{l}1.6 \\
1.5 \\
1.7\end{array}$ & $\begin{array}{l}5.4 \\
5.2 \\
5.9\end{array}$ & $\begin{array}{l}5.8 \\
5.1 \\
6.5\end{array}$ & $\begin{array}{l}19.3 \\
18.1 \\
20.7\end{array}$ & $\begin{array}{l}7.7 \\
7.2 \\
8.8\end{array}$ & $\begin{array}{l}7.7 \\
7.5 \\
7.9\end{array}$ & $\begin{array}{l}7.9 \\
7.8 \\
8.4\end{array}$ & $\begin{array}{l}13.0 \\
12.7 \\
13.7\end{array}$ & $\begin{array}{l}7.2 \\
6.8 \\
7.8\end{array}$ & $\begin{array}{l}7.2 \\
6.8 \\
7.5\end{array}$ & $\begin{array}{l}13.6 \\
12.7 \\
14.9\end{array}$ & $\begin{array}{l}4.0 \\
3.7 \\
4.3\end{array}$ & $\begin{array}{l}2.2 \\
1.9 \\
2.6\end{array}$ & $\begin{array}{l}2.5 \\
1.9 \\
3.2\end{array}$ & $\begin{array}{l}- \\
- \\
-\end{array}$ & $\begin{array}{l}12.6 \\
11.8 \\
13.4\end{array}$ \\
\hline
\end{tabular}

D et. C. Willemse; Type [red label]; [label 1 fac simile]; TYPEORTH : 906, Gryllacris poultoni, Willemse's. ㅇ (UMO). Examined.

Vanuatu. (9 $0^{7} 0^{\pi}, 8$ \% $\left.९\right)$, Sanma Province, Espiritu Santo Is., Big Bay, Matantas, Vatthé Conservation area, $15^{\circ} 20^{\prime} \mathrm{S}, 166^{\circ} 95^{\prime} \mathrm{E}$, sous-bois, nuit, Exped. Santo 2006, 25.X.2006, coll. S. Hugel, 2 o $^{7} \mathrm{O}^{7}$ (SH-022, SH-023) (MNHN-ENSIF2167, 2168). - Big Bay, Matantas, Vatthé Lodge, forêt autour de la grotte, $15^{\circ} 10^{\prime} 48^{\prime \prime}$, $166^{\circ} 57^{\prime} 27^{\prime \prime} \mathrm{E}, 30 \mathrm{~m}$ alt., sous-bois, nuit, Exped. Santo 2006, 27.X.2006, coll. S. Hugel, 2 O' $^{7}$ (SH-009, SH-020) (MNHN-ENSIF2161, 2165); 1 우 (SH-014) (MNHNENSIF2174).

Peavot, 1459'37"S, 16647'04”E, $38 \mathrm{~m}$ alt., forêt secondaire, ancien jardin, nuit, Exped. Santo 2006, 20.X.2006, coll. S. Hugel, 1 ơ (SH-015) (MNHNENSIF2162); coll. T. Robillard, 1 \& (SH-010) (MNHNENSIF2170). - Peavot, 1459'37”S, 16647'04”E, $38 \mathrm{~m}$ alt., forêt secondaire, ancien jardin, Exped. Santo 2006, 21.X.2006, coll. S. Hugel, 1 O (SH-017) (MNHN-ENSIF2163); coll. T. Robillard, 10' (SH-018) (MNHN-ENSIF2164); coll. S. Hugel, $10^{\circ}$ (SH-024) (MNHN-ENSIF2169); coll. S. Hugel, 4 \% $($ (SH-012, SH-013, SH-016, SH-025) (MNHN-ENSIF2172, 2173, 2175, 2177). - Peavot, Mt Nouresororo, 1459'26”S, $166^{\circ} 45^{\prime} 14$ ”'E, $636 \mathrm{~m}$ alt., forêt de brume, nuit, Exped. Santo 2006, 22.X.2006, coll. S. Hugel, 1 ९ (SH-011) (MNHN-ENSIF2171).

Penaoru, camp de base, Exped. Santo 2006, 19.X.2006, coll. E. Boitier, 1 ㅇ (SH-019) (MNHNENSIF2176).

Luganville, Site du CTRAV, [no precision], Exped. Santo 2006, 1 (SH-021) (MNHN-ENSIF2166).

Distribution. - Vanuatu, Sanma Province: Elephant island (east of Espiritu Santo); Espiritu Santo Isl. The holotype is from "New Heb" [rides] (Vanuatu), without more precise locality data.
DiagnOSIS. - Compared to other Amphibologryllacris species, $A$. macrocera displays important variations in coloration and in a lesser extent in morphology. Among Amphibologryllacris, the species is characterized by the following.

Size medium for the genus: FIII: 12.2-14.9 mm (10.2$11.8 \mathrm{~mm}$ in A. butmasi n. sp.), FW: $17.5-21.7 \mathrm{~mm}$ (much less than $18 \mathrm{~mm}$ in $A$. oceanica (Le Guillou, 1841) and 15.1-18.0 $\mathrm{mm}$ in A. butmasi n. sp.). Head: with black pattern, often very distinct (unlike $A$. ferruginea (Brunner von Wattenwyl, 1888) and A. cyaneoterminata (Karny, 1935), which lack black pattern). Median and lateral ocelli clearly distinct, pink. Median ocellus wide, only slightly less wide than fastigium frontis (Fig. 2F, unlike A. oceanica having a small ocellus and $A$. cyaneoterminata with no visible ocellus in 9 holotype).

FW: usually with 4 or 5 precostal veins (Fig. 4B; unlike $A$. butmasi n. sp. having 2 or 3 precostal veins); $\mathrm{M}$ neither fused with Rs (unlike $A$. ferruginea, Fig. 4C) nor fused with $\mathrm{Cu}$ (unlike $A$. painei (Karny, 1935), Fig. 4D); $\mathrm{M}$ usually simple, Cu usually with 3 branches (2 bifurcations).

Legs: TI and TII not darkened, neither at the middle (unlike $A$. oceanica) nor near the knee (unlike in $A$. dubia and A. cyaneoterminata).

Male appendices cerciferae long, lying head-to-tail, side by side (Fig. 3C; the processes are short in A. ferruginea (Fig. 5C) and according to Karny (1935) similar to A. ferruginea in A. painei). Male SGP with a shallow, but distinct emargination (Fig. 5C; no emargination in $A$. ferruginea and $A$. painei, deeper emargination in A. butmasi n. sp.: Fig. 5A). Female with the sternite preceding the SPG (VII) forming a protrusion with an oval apex (Fig. 3D; sometimes bulging but never protruding in A. dubia, A. ferruginea and A. cyaneoterminata). Ovipositor 11.8$13.7 \mathrm{~mm}$ (9.3-10.4 $\mathrm{mm}$ in A. butmasi n. sp.).

MeAsurements. - See Table 1. 

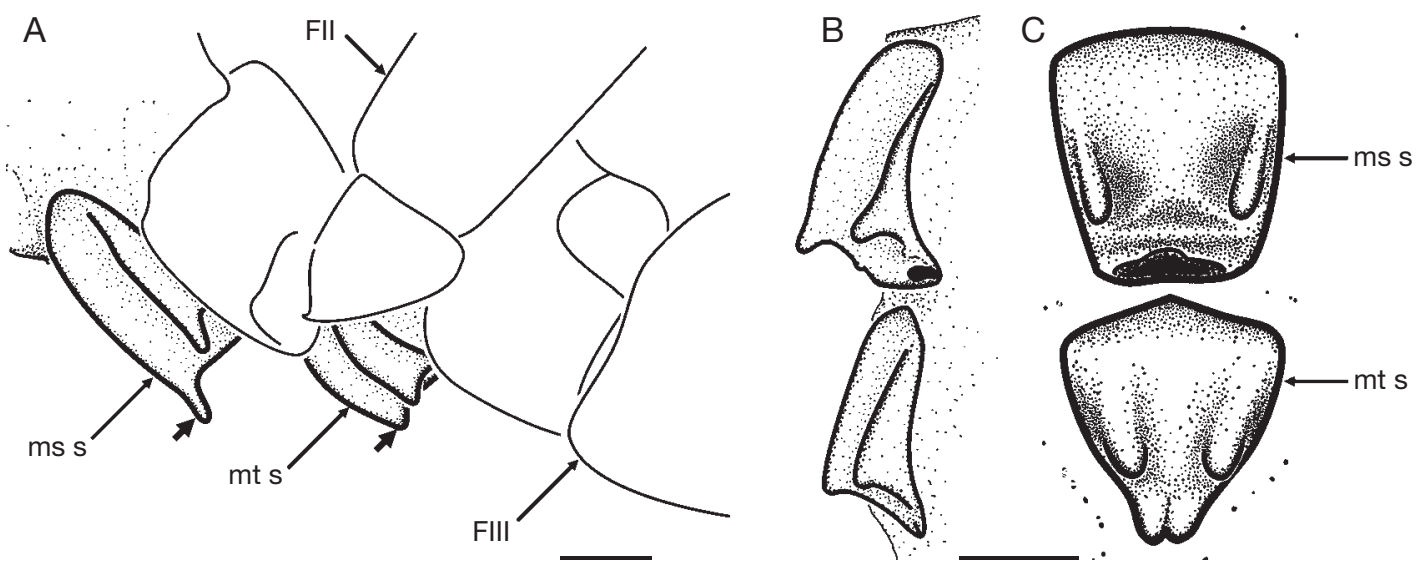

Fig. 1. - Amphibologryllacris Karny, 1937, sternum: A, A. macrocera (Walker, 1869), left side view, note the pointing lateral lobes (arrows); B, C, A. butmasi n. sp., left side (B) and ventral (C) views. Abbreviations: see text. Scale bars: $1 \mathrm{~mm}$.

\section{REDESCRIPTION}

In addition to generic characters. Body length: size medium for the genus. Head (Fig. 2F): as broad or slightly broader than the thorax; fastigium frontis distinctly wider than scapus; face maximal width (in frontal view, below the eyes) 3.8 times (min: 3.5; max: 4.1; holotype: 3.5; 9 described as $A$. poultoni holotype: 3.8 ) as wide as fastigium frontis (measured above median ocellus); median and lateral ocelli clearly distinct, median ocellus oval, wider than half fastigium frontis width.

Thorax. Pronotum: maximal width 1.1 times (min: 0.9; max: 1.1; holotype: 1.0; ㅇ described as A. poultoni holotype 1.1) wider than maximal length; anterior margin convex (in dorsal view), arched; posterior margin strait (in dorsal view), almost horizontal; anterior sulcus deep on lateral lobes and well distinct on discus; posterior sulcus shallower and less distinct on discus; both sulci converging on lateral lobes; prozona elevated; metazona narrower than pronotum anterior part, flattened; lateral lobe/ discus angle sub acute (frontal view). Sternum (see Amphibologryllacris diagnosis and Figure 1A): spines on mesosternum lateral lobes long with blunt apex, spines on metasternum much shorter, blunt.

Wings. FW (Fig. 4B): with 4 precostal veins, rarely $5(2 / 19$ specimens) or $3(2 / 19)$ and then usually on one FW only); R divided in 4 veins (3 bifurcations); $\mathrm{M}$ simple (not divided); $\mathrm{M}$ rarely
(3/19) contacting punctually Rs; Cu usually divided in 3 veins ( 2 bifurcations), rarely divided in 2 secondary veins (usually on one FW only); 6 A veins, sometimes $7(5 / 19)$, rarely $8(1 / 19$, only one FW). HW exceeding slightly FW.

Legs. Forelegs and mid legs with usual spurs formula ( 4 pairs of subapical +1 pair of apical spurs ventrally, and one single apical spur on TII dorsally); subapical spurs of usual length (longer than T width). Hind legs (Fig. 2D): femora 3.4 times as long as wide (range: 3.1-3.6 holotype: 3.5; A. poultoni holotype: 3.2); FIII with 13-17 ventral inner spines (usually 15-16; holotype: 14-15; A. poultoni holotype: 15); FIII with 8-13 spines (usually 10-12; holotype: $8-11 ; A$. poultoni holotype: 9); TIII with 6 -7 dorsal inner spines (holotype: 6; $A$. poultoni holotype: 7); with 6-7 ventral outer spines (holotype 6-7; A. poultoni holotype: 7).

\section{Colour}

As in many gryllacridids, coloration strongly variable, particularly the presence and extent of black patterns which are sometimes almost lacking. Whereas the male holotype displays few such patterns, these are well developed in the female described as $A$. poultoni holotype (considered here as a simple variety of A. macrocera). Head: face with pale dark to black patterns: paired spots on the face, the clypeus and around the median ocellus; stripe above the clypeus 

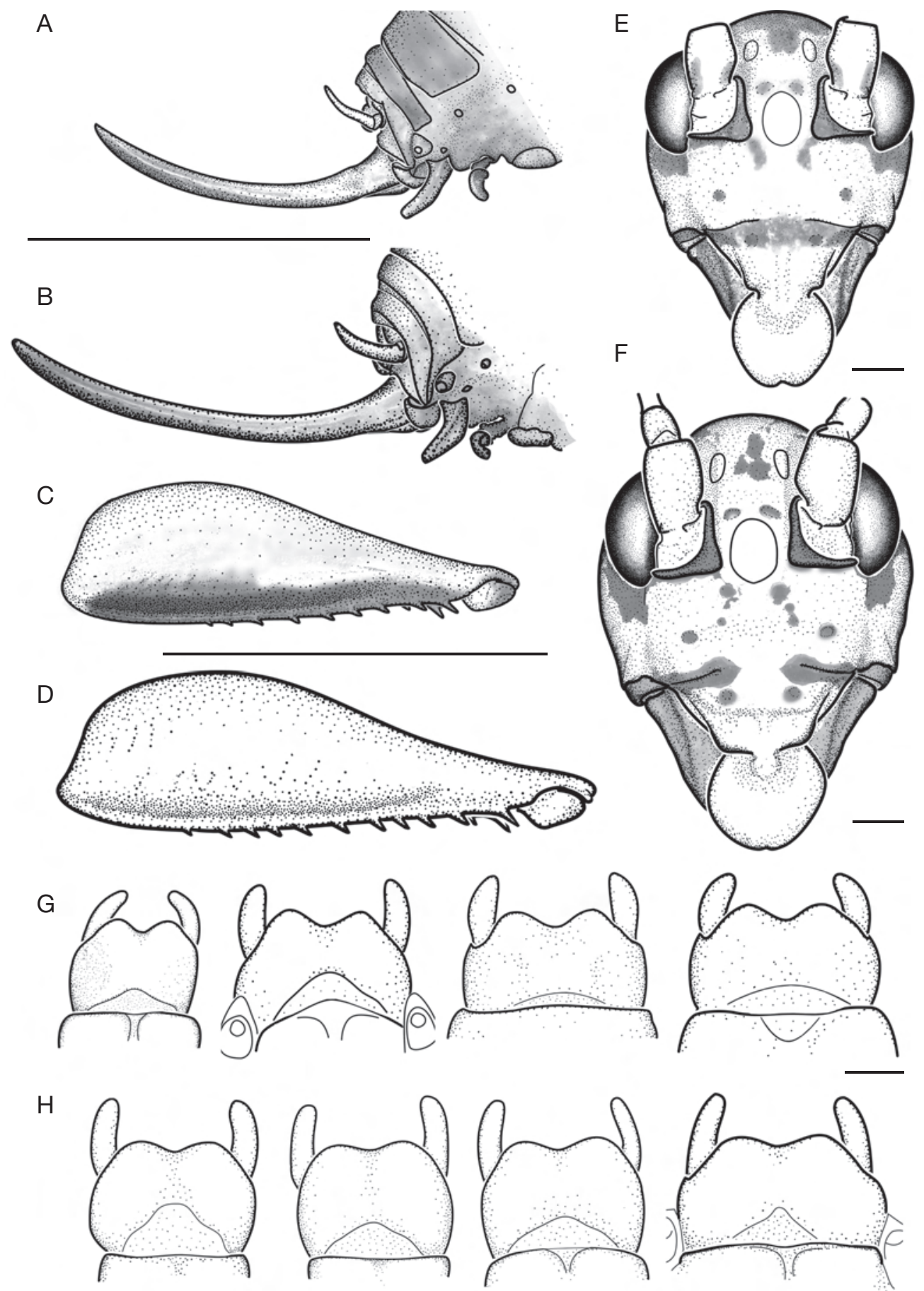

FIG. 2. - Amphibologryllacris Karny, 1937 from Espiritu Santo: A, C, E, G, A. butmasi n. sp.; B, D, F, H, A. macrocera (Walker, 1869); A, B, ovipositor, right side view; C, D, left femur III side view; E, F, face; G, H, ventral views of male subgenital plate showing intraspecific variation (the four specimens on the right side are alcohol preserved). Scale bars: A-D, $10 \mathrm{~mm} ; \mathrm{E}-\mathrm{H}, 1 \mathrm{~mm}$. 
(usually interrupted on the middle); stripe on the antennal socket ventral margin; whole socket black; circular stripe surrounding the eyes posteriorly and converging in front of the occiput, without covering the occiput. Ocelli pinkish. Scapus not darkened, except sometimes a lateral macula. Pronotum usually (16/19 specimens) poorly darkened, with only few dark or black spots on the sulci and depressions; rarely (3/19 specimens) the fine margin surrounding the whole pronotum is black. FW with pale yellowish veins; usually with some smoked cells, rarely none (3/19 specimens including the holotype) or most (3/19 specimens including $A$. poultoni holotype). HW usually smoked (except around transverse veinlets where it is hyaline), extent of this darkening variable; in few specimens (3/19 including the holotype) darkening inconspicuous. Legs usually uniformly brown/yellowish; rarely (3/19 specimens including A. poultoni holotype) with black on femora ventral margin. Abdominal tergites usually brown/yellowish; rarely (4/19 specimens including $A$. poultoni holotype) abdominal tergites darkened.

\section{SEXUAL DIMORPHISM}

Apart from primary sexual characters, $0^{\prime} 0^{\prime \prime}$ are slightly smaller than $ᄋ$ (TIII length $13.2 \pm 0.2 \mathrm{~mm}, \mathrm{n}=$ 10 vs. $13.6 \pm 0.2 \mathrm{~mm}, \mathrm{n}=9)$.

\section{Male}

Genitalia (Fig. 3C) of Brunner's type A (Brunner von Wattenwyl 1888). Tergite VIII not modified compared to preceding tergites. Tergite IX not extended; end of tergite bent backwards/downwards, with a minute median emargination on posterior margin. Appendices cerciferae base enclaved between tergite IX lateral lobes and tergite end; appendices cerciferae with a process forming a long coiled spur with an acute apex, the spur bent at the base; on dead specimens, both appendices cerciferae processes lying head-to-tail, side by side; length and angle of process bent variable within the species without discrete classes. SGP with a shallow emargination (Fig. 2H); styli not thickened (length: $1.35 \pm 0.02 \mathrm{~mm}$ ).

\section{Female (Figs 2B; 3D)}

Sternite before SGP (VII): bearing a long process on sternite anterior margin, directed backwards; reaching usually SGP base (depending on stuffing); process base weakly sclerotized, flat; process apex ladle-shaped with the concavity directed ventrally (the curvature depends on the preservation), the dorsal part strongly sclerotized.

\section{REMARKS}

Karny (1937) synonymised $A$. poultoni with $A$. macrocera as a variety (not as a subspecies as stated in Otte [2000]), and Otte (2000) implicitly rose A. macrocera var. poultoni to species (without the usual statement "2000 Otte, this work"). The numerous specimens collected in Santo allow to confirm Karny (1937) in considering the female specimen described by Willemse (1925) under Gryllacris poultoni as a melanised morph of $A$. macrocera.

\section{Amphibologryllacris butmasi $\mathrm{n}$. sp.}

(Figs 1B, C; 2A, C, E, G; 3A, B, E-G; 4A)

Type Material. - Holotype: Vanuatu. Sanma Province, Espiritu Santo Isl., Butmas, forêt sur plateau de Tankara, $15^{\circ} 21^{\prime} 56^{\prime}$ S, 166 59'04”E, 600 m alt., nuit, Exped. Santo 2006, 13.X.2006, coll. S. Hugel, ơ (SH-030) (MNHN-ENSIF2178).

Allotype: same locality and collector as holotype, nuit, 14.X.2006, ㅇ (SH-026) (MNHN-ENSIF2185).

Paratypes: same locality and collector as holotype, nuit, 13.X.2006, 3 ơ o' (SH-029, SH-033, SH-034) (MNHN-ENSIF2180, 2183, 2184). — Same locality, 16.X.2006, coll. T. Robillard, $10^{\circ}$ (SH-027) (MNHNENSIF2179).

Butmas E village, bord de chemin, Exped. Santo 2006, 16.X.2006, coll. S. Hugel, 2 o' o' (SH-031, SH-032) (MNHN-ENSIF2181, 2182). — Butmas, forêt sur plateau de Tankara, 15²1'56"S, 16659'E, $600 \mathrm{~m}$ alt., nuit, Exped. Santo 2006, 16.X.2006, coll. T. Robillard, 1 ㅇ (SH-028) (MNHN-ENSIF2186).

TyPE LOCALITY. - Vanuatu, Espiritu Santo Is., plateau of Tankara, near the village of Butmas.

Distribution. - Vanuatu, Sanma Province, Espiritu Santo Isl., Butmas, Tankara plateau.

Etymology. - After Butmas, the type locality.

HABITAT AND LIFE HISTORY TRAITS. — Some specimens of $A$. butmasi n. sp. have been observed during night hours rushing on branches and foliage (1-4 m) while exploring the surroundings with their tremendously long antennas. 
TABLE 2. - Measurements of Amphibologryllacris butmasi n. sp. Abbreviations: see text. Notes: 1, frontal view base of scapus level; $\mathbf{2}, \mathbf{4}$, depends on the preservation; $\mathbf{3}$, depends on the wing arching.

\begin{tabular}{|c|c|c|c|c|c|c|c|c|c|c|c|c|c|c|c|c|c|c|}
\hline & \multirow{2}{*}{$\begin{array}{c}\text { Bd } \\
\text { L }\end{array}$} & \multirow{2}{*}{$\begin{array}{c}\text { Hd } \\
\text { w } \\
\text { max. }\end{array}$} & \multirow{2}{*}{$\begin{array}{c}\text { FFr1 } \\
\text { W }\end{array}$} & \multicolumn{2}{|c|}{ Prn } & \multicolumn{2}{|c|}{ FW } & \multirow{2}{*}{$\begin{array}{l}\text { TI } \\
\text { L }\end{array}$} & \multirow{2}{*}{$\begin{array}{l}\text { TII } \\
\text { L }\end{array}$} & \multirow{2}{*}{$\begin{array}{c}\text { TIII } \\
\mathbf{L}\end{array}$} & \multirow{2}{*}{$\begin{array}{l}\text { FI } \\
\text { L }\end{array}$} & \multirow{2}{*}{$\begin{array}{c}\text { FII } \\
\text { L }\end{array}$} & \multicolumn{2}{|c|}{ FIII } & \multicolumn{2}{|c|}{ SGP } & \multirow{2}{*}{$\begin{array}{c}\text { Sty } \\
\text { L }\end{array}$} & \multirow{2}{*}{$\begin{array}{c}\text { Ovs } \\
\mathrm{L}\end{array}$} \\
\hline & & & & $\mathbf{L}$ & $\begin{array}{c}\mathbf{W}^{2} \\
\text { max. }\end{array}$ & $\mathbf{L}$ & $\begin{array}{l}\mathbf{W}^{3} \\
\text { mid. }\end{array}$ & & & & & & $\mathbf{L}$ & $\begin{array}{c}\text { W } \\
\text { max. }\end{array}$ & $\begin{array}{c}\mathbf{L} \\
\text { max. }\end{array}$ & $\begin{array}{c}\text { W4}^{4} \\
\text { base }\end{array}$ & & \\
\hline $0^{\pi}$ holotype & 19.3 & 5.5 & 1.4 & 4.7 & 5.0 & 16.6 & 6.6 & 6.5 & 6.8 & 10.6 & 6.2 & 6.2 & 11.2 & 3.6 & 1.5 & 2.0 & 1.0 & - \\
\hline @ allotype & 23.0 & 5.5 & 1.4 & 4.8 & 5.3 & 16.2 & 5.7 & 6.8 & 6.2 & 10.9 & 6.2 & 6.2 & 11.5 & 3.7 & 2.2 & 2.5 & - & 9.3 \\
\hline $\begin{array}{c}\sigma^{\top} \mathrm{n}=7 \\
\min . \\
\max .\end{array}$ & $\begin{array}{l}21.9 \\
15.4 \\
26.6\end{array}$ & $\begin{array}{l}5.3 \\
5.1 \\
5.5\end{array}$ & $\begin{array}{l}1.4 \\
1.4 \\
1.5\end{array}$ & $\begin{array}{l}4.7 \\
4.3 \\
5.1\end{array}$ & $\begin{array}{l}5.3 \\
5.0 \\
5.9\end{array}$ & $\begin{array}{l}16.4 \\
15.1 \\
18.0\end{array}$ & $\begin{array}{l}6.6 \\
5.9 \\
7.1\end{array}$ & $\begin{array}{l}6.4 \\
6.1 \\
7.0\end{array}$ & $\begin{array}{l}6.6 \\
6.2 \\
7.3\end{array}$ & $\begin{array}{r}10.3 \\
9.8 \\
11.4\end{array}$ & $\begin{array}{l}5.9 \\
5.6 \\
6.2\end{array}$ & $\begin{array}{l}6.2 \\
5.9 \\
6.6\end{array}$ & $\begin{array}{l}11.2 \\
10.2 \\
11.7\end{array}$ & $\begin{array}{l}3.4 \\
3.2 \\
3.7\end{array}$ & $\begin{array}{l}1.6 \\
1.5 \\
1.8\end{array}$ & $\begin{array}{l}2.5 \\
1.9 \\
3.0\end{array}$ & $\begin{array}{l}1.1 \\
0.9 \\
1.2\end{array}$ & $\begin{array}{l}- \\
- \\
-\end{array}$ \\
\hline $9 \mathrm{n}=2$ & 23.7 & 5.6 & 1.4 & 5.0 & 5.6 & 16.4 & 6.5 & 6.9 & 6.7 & 11.1 & 6.1 & 6.2 & 11.6 & 3.8 & 2.2 & 2.7 & - & 9.9 \\
\hline \% paratype & 24.4 & 5.7 & 1.5 & 5.1 & 5.9 & 16.5 & 7.2 & 7.0 & 7.1 & 11.4 & 6.1 & 6.2 & 11.8 & 3.9 & 2.1 & 2.9 & - & 10.4 \\
\hline
\end{tabular}

DiAGNOSIS. - Compared to other Amphibologryllacris species. Size rather small for the genus: FIII: 10.2-11.8 mm, FW: 15.1-18.0 mm. Head: with very distinct black pattern (unlike $A$. ferruginea and $A$. cyaneoterminata lacking black pattern). Median and lateral ocelli clearly distinct (Fig. 2E), pink. Median ocellus wide, only slightly less wide than fastigium frontis (Fig. 2E; unlike A. oceanica having a small ocellus and $A$. cyaneoterminata with no visible ocellus in the 9 holotype).

FW (Fig. 4A): $\mathrm{M}$ neither fused with Rs (unlike A. ferruginea, Fig. 4C) nor with $\mathrm{Cu}$ (unlike $A$. painei, Fig. 4D); $\mathrm{M}$ usually simple, Cu usually with 3 branches (2 bifurcations).

Legs: TI and TII not darkened, neither at mid length (unlike A. oceanica) nor near the knee (unlike in A. dubia and $A$. cyaneoterminata).

Male appendices cerciferae long, lying head-to-tail, side by side (processes short in $A$. ferruginea and, according to Karny [1935], similar to $A$. ferruginea in $A$. painei). Male SGP with a distinct emargination (Fig. 2G; no emargination in $A$. ferruginea and $A$. painei). Female sternite preceding the SGP (VII) forming a protrusion with an oval apex (Figs 2A; 3B; sometimes bulging but not protruding in $A$. dubia, A. ferruginea and $A$. cyaneoterminata, Fig. 5).

Amphibologryllacris butmasi n. sp. is extremely close to A. macrocera and differs by (see Figs 2; 3E): its shorter size (e.g., [see also Tables 1 and 2], FIII: 10.2-11.8 mm vs. $12.2-14.9 \mathrm{~mm}$ in $A$. macrocera; FW: $15.1-18.0 \mathrm{~mm}$ vs. 17.5-21.7 $\mathrm{mm}$ in A. macrocera; ovipositor $9.3-10.4 \mathrm{~mm}$ vs. $11.8-13.7 \mathrm{~mm}$ in $A$. macrocera); FW with 2 or 3 precostal veins (Fig. 4A; usually 4 or 5 precostal veins in A. macrocera, Fig. 4B); pronotum discus posterior sulcus well distinct, metazona bulging; male SGP with a distinct emargination (Fig. 2G; shallower emargination in $A$. macrocera: Fig. $2 \mathrm{H}$ ), styli shorter (length: 1.08 $\pm 0.02 \mathrm{~mm}$ vs. $1.35 \pm 0.02 \mathrm{~mm}$ in A. macrocera) and thicker than in A. macrocera. Amphibologryllacris butmasi n. sp. differs also from $A$. macrocera by its general darker coloration: head always with distinct black pattern, pronotum always encircled by a black margin; pronotum discus anterior sulcus and prozona darkened; sulci darkened on lateral lobes; FW always with numerous well smoked cells, femora always with black ventrally; abdominal tergites always black.

Measurements. - See Table 2.

\section{DESCRIPTION}

In addition to generic characters. Body length: size small for the genus. Head (Fig. 2E): as broad or slightly broader than the thorax; fastigium frontis distinctly wider than scapus; face maximal width (in frontal view, below the eyes) 3.8 times (min: 3.5; max: 4.0; holotype: 4.0; allotype: 3.9 ) as wide as fastigium frontis (measured above median ocellus); median and lateral ocelli clearly distinct, median ocellus oval, wide as half of the fastigium frontis width. Thorax: pronotum: maximal width 1.1 times (min: 1.1; max: 1.2; holotype: 1.1; allotype 1.1) wider than maximal length; anterior margin convex (in dorsal view), arched; posterior margin strait (in dorsal view), almost horizontal; anterior sulcus deep on lateral lobes and well distinct on discus; posterior sulcus well distinct on discus; both sulci converging on lateral lobes; prozona elevated; metazona narrower than pronotum prozona, bulging; lateral lobe/discus angle sub acute (frontal view). Sternum (Fig. 1B, C; see Amphibologryllacris diagnosis): spines on mesosternum lateral lobes short with blunt apex, spines on metasternum inconspicuous, 

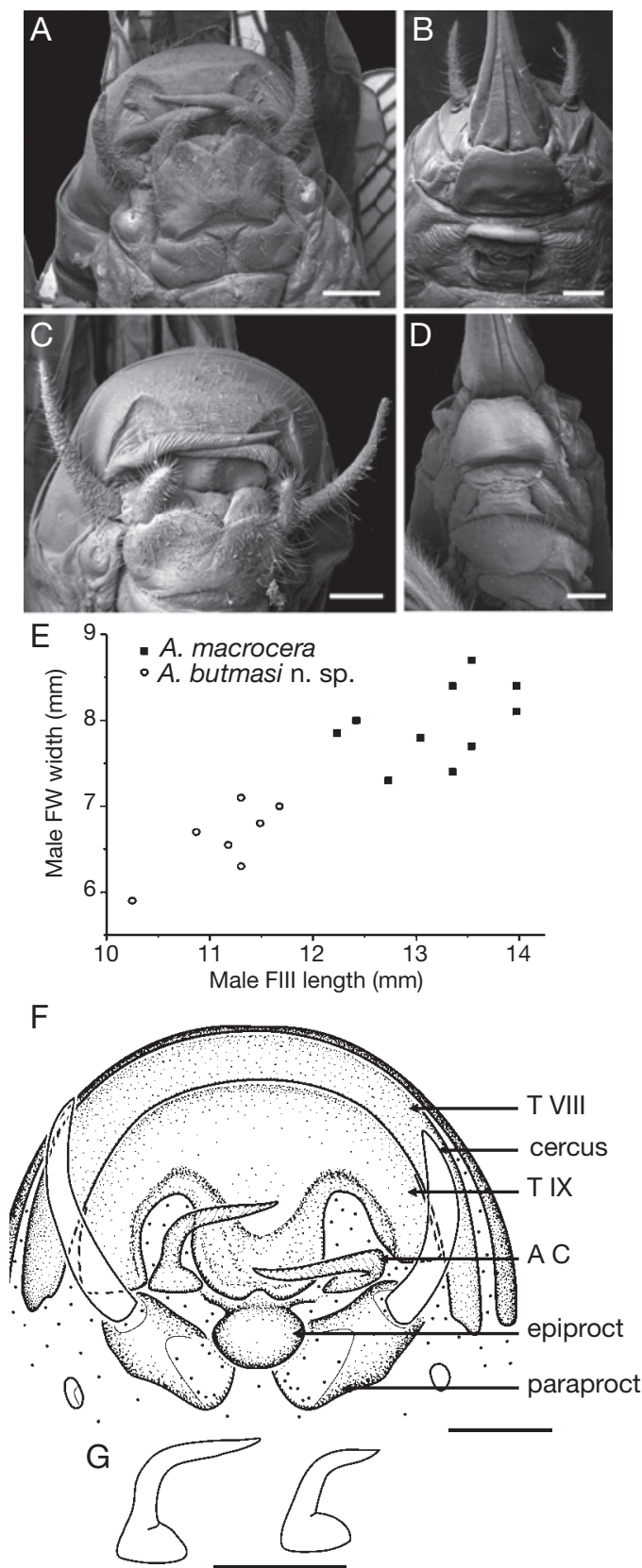

FIG. 3. - Amphibologryllacris Karny, 1937 from Espiritu Santo: A, B, F, G, A. butmasi n. sp.; C, D, A. macrocera (Walker, 1869); A, C, ventral view of male terminalia; $\mathbf{B}, \mathbf{D}$, ventral view of female terminalia; E, distribution of male forewing width as a function of femur III length, note the discontinuous measurement distribution on both species; $\mathbf{F}$, male terminalia in posterior view (the subgenital plate removed), the right appendice cercifera is flipped downwards; $\mathbf{G}$, ventral views of left appendice cercifera from two specimens, note the strong variation in shape. Abbreviations: see text. Scale bars: $1 \mathrm{~mm}$.

blunt. FW (Fig. 4A): with 2 or 3 precostal veins; R divided in 4 veins ( 3 bifurcations), rarely 5 veins ( 4 bifurcations); $\mathrm{M}$ simple (not divided); $\mathrm{M}$ sometimes (3/9) contacting punctually Rs, rarely contacting punctually $\mathrm{Cu}$; $\mathrm{Cu}$ usually divided in 3 veins ( 2 bifurcations), rarely divided in 2 secondary veins (usually on one $\mathrm{FW}$ only, $\mathrm{n}=2 / 9$ ); 6 A veins, rarely 5 (1/9). HW exceeding slightly FW. TI and TII with usual spur formula (4 pairs of subapical +1 pair of apical spurs ventrally, and one single apical spur on TII dorsally); subapical spurs of usual length (longer than tibia width). FIII 3.3 times as long as wide (range: 3.0-3.6 holotype: 3.1; allotype: 3.1); FIII (Fig. 2C) with 12-16 ventral inner spines (holotype: 13-14; allotype: 14-16); FIII with 7-12 spines (usually 9-11; holotype: 9-11; allotype: 9); TIII with 5-7 dorsal inner spines (holotype: 6-7; allotype: 6); with 6-7 ventral outer spines (holotype 6-7; allotype: 7).

\section{Colour}

Coloration more stable than in A. macrocera, although somewhat variable. Head: face with black patterns: paired spots on the face, the clypeus and around the median ocellus; continuous stripe above the clypeus; stripe on the antennal socket ventral margin; whole socket black; circular stripe surrounding the eyes posteriorly and converging in front of the occiput, without covering the occiput, median part of the occiput often with a black triangle pointing anteriorad. Ocelli pinkish. Scapus not darkened, except sometimes a lateral macula. Pronotum usually (16/19 specimens) strongly darkened, with black sulci and depressions; the fine margin surrounding the whole pronotum always black; prozona always darkened/black. FW with pale yellowish veins; with most cells smoked (except precostal area). HW smoked (except around transverse veinlets), rarely weakly (1/9 specimen). Legs always with black on femora ventral margin. Abdominal tergites always black.

\section{SEXUAL DIMORPHISM}

Apart from primary sexual characters, males smaller than females (TIII length $10.3 \pm 0.2 \mathrm{~mm}, \mathrm{n}=7$ vs. $11.1 \pm 0.2 \mathrm{~mm}, \mathrm{n}=2)$. 
A

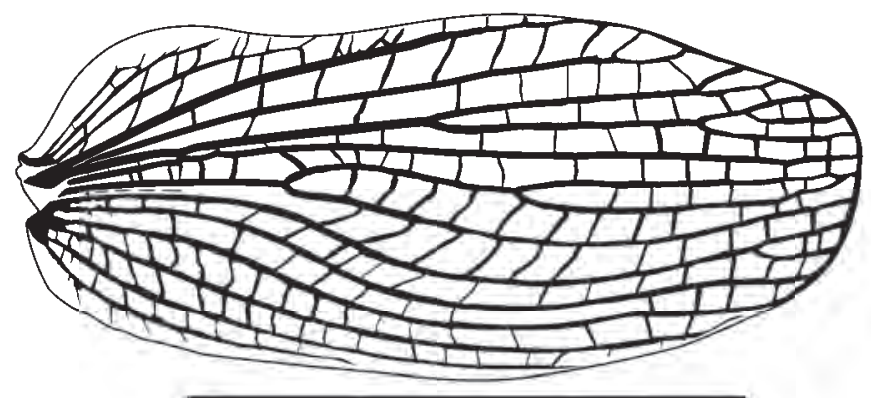

B
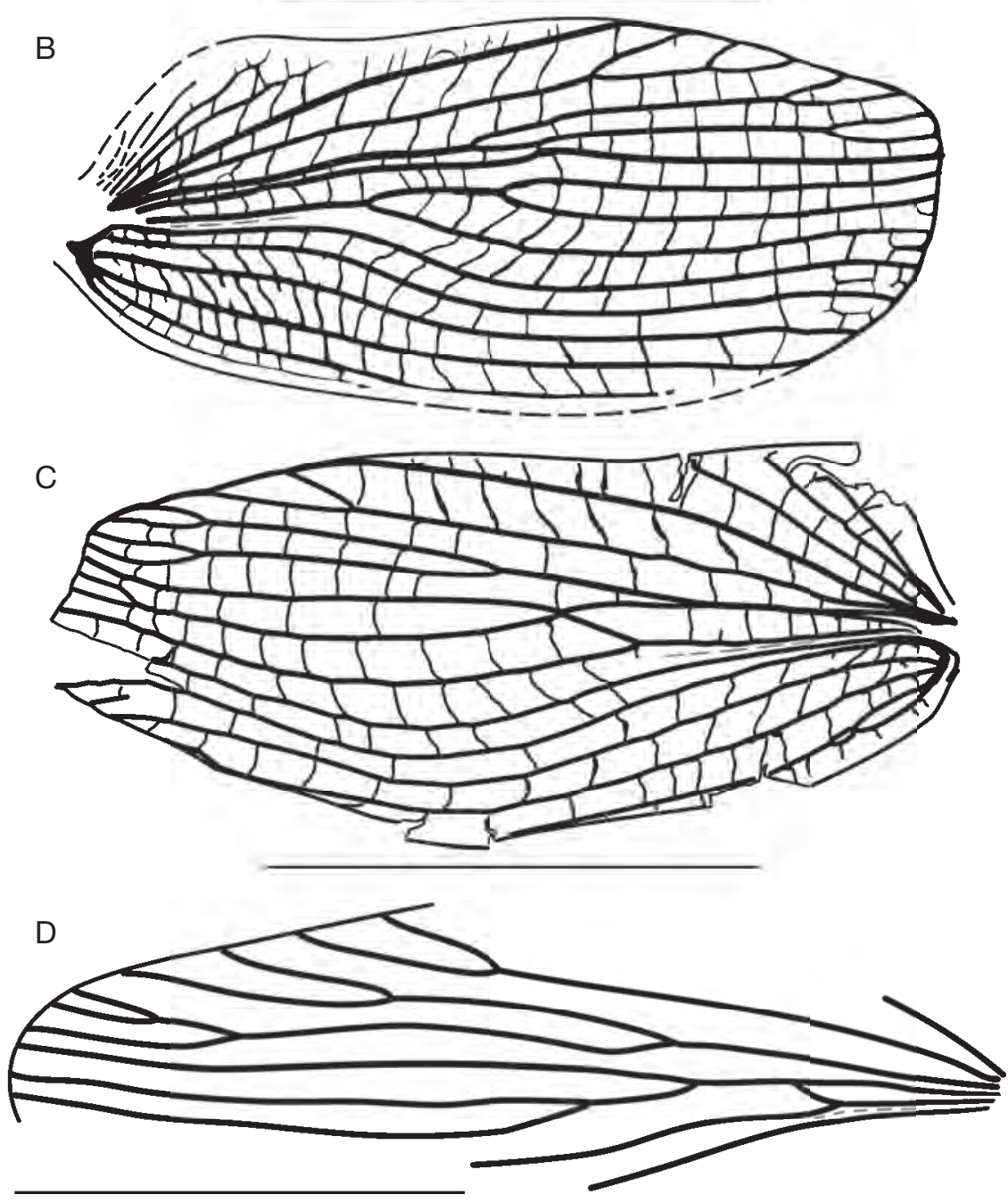

FIG. 4. - Amphibologryllacris Karny, 1937, forewing: A, A. butmasi n. sp.; B, A. macrocera (Walker, 1869), holotype; C, A. ferruginea (Brunner von Wattenwyl, 1888), holotype (NHW); D, A. painei (Karny, 1935) (after Karny 1935). The grey dotted lines correspond to the claval fold. Scale bars: $10 \mathrm{~mm}$. 
A
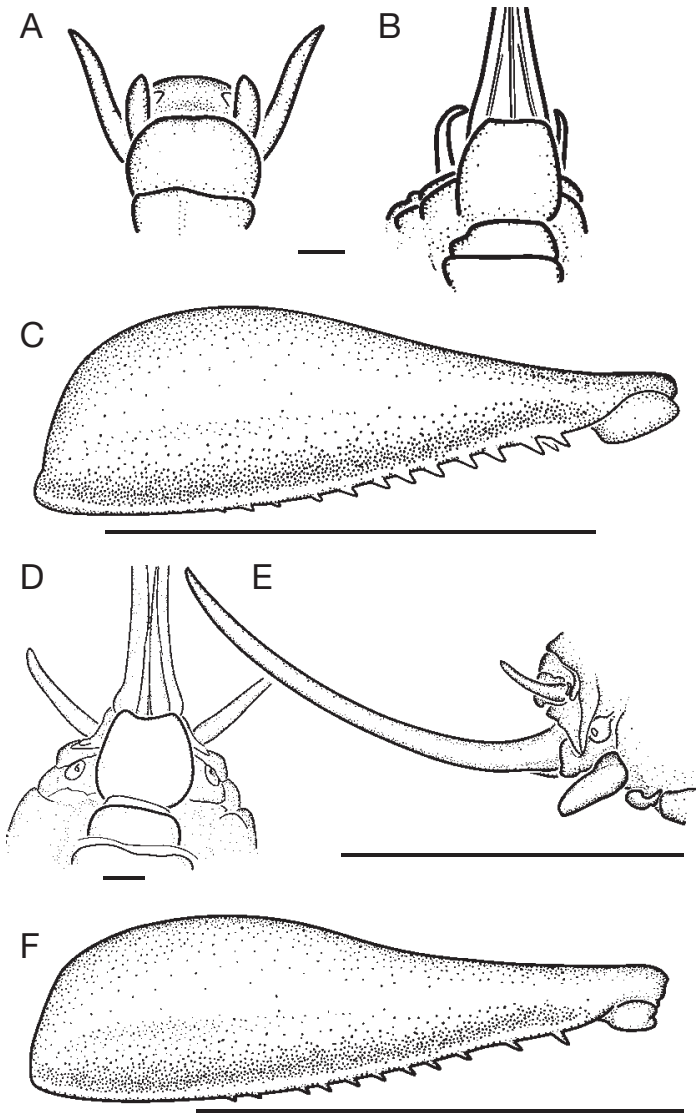

FIG. 5. - Amphibologryllacris Karny, 1937: A-C, A. ferruginea (Brunner von Wattenwyl, 1888), type specimens (NHW); D-F, A. dubia (Le Guillou, 1841), non type female from Fiji Islands, identified by Karny (Vana-Levu, Jalave, 1926, ZMUH); A, ventral view of male holotype terminalia; $\mathbf{B}$, ventral view of female terminalia; C, lateral view of male holotype left femur III; $\mathbf{D}$, ventral view of female terminalia; $\mathbf{E}$, right side view of female subgenital plate and ovipositor; $\mathbf{F}$, lateral view of left femur III. Scale bars: A, B, D, $1 \mathrm{~mm}$; C, E, F, $10 \mathrm{~mm}$.

\section{Male}

Terminalia (Fig. 3A, B, F) of Brunner's type A (Brunner von Wattenwyl 1888). T VIII not modified compared to preceding tergites. T IX not extended; end of tergite bent backwards/ downwards, with a minute median emargination on posterior margin. Appendices cerciferae (Fig. 3F, G) base enclaved between T IX lateral lobes and tergite end; appendices cerciferae with a process forming a long coiled spur with an acute apex, the spur bent basally; on dead specimens, both appendices cerciferae processes lying head-to-tail, side by side; the length and the angle of process bent variable within the species without discrete classes; SGP with a distinct emargination (Fig. 3G); styli short and thick.

\section{Female}

Sternite before SGP (VII): bearing a long process on anterior margin, directed backwards (Figs 2A; 3B); reaching usually SGP base (depending on stuffing); process base weakly sclerotized, flat; process apex ladle-shaped with the concavity directed ventrally (the curvature depends on the preservation), the dorsal part strongly sclerotized.

STATUS OF AMPHIBOLOGRYLLACRIS BUTMASIN. SP. Amphibologryllacris butmasi n. sp. specimens of the type series are displaying weak but clear differences with all $A$. macrocera examined specimens. Importantly, most of these differences are size or colour characters, and few are discrete characters (and these might be linked to size reduction).

As discrete characters are available and as for most of the non discrete characters, intermediate forms (i.e. between $A$. macrocera and $A$. butmasi n. sp.) are lacking (Fig. 3E), I decide to describe the specimens collected in Butmas as a new species.

Nevertheless, as most $A$. macrocera specimens have been collected at a low altitude ( $>50 \mathrm{~m})$ with distinct climatic conditions, it can not be entirely excluded that what I consider here as being a distinct species would represent an ecotype, involving allometric morphological changes.

\section{Genus Nannogryllacris Karny, 1937}

(Figs 5-7)

\section{Nannogryllacris Karny, 1937: 133.}

TYPE SPECIES. - Gryllacris exigua Brunner von Wattenwyl, 1888.

Diagnosis (IN ADDITION TO THE ABOVE-MENTIONED CHARACTERS SHARED WITH AMPHIBOLOGRYLLACRIS). Size: small; body length: $12.5-20 \mathrm{~mm}$; FIII: $6.2-12 \mathrm{~mm}$; FW: 9-17 mm. Colour: light brown, without clear black drawings (neither on face, pronotum, abdomen, legs); FW veins concolourous with the FW cells. Cerci usually 
A

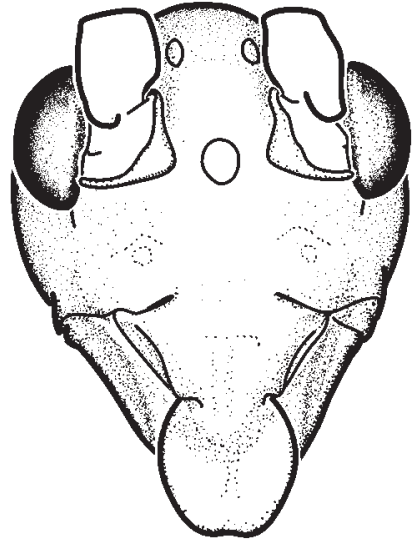

B

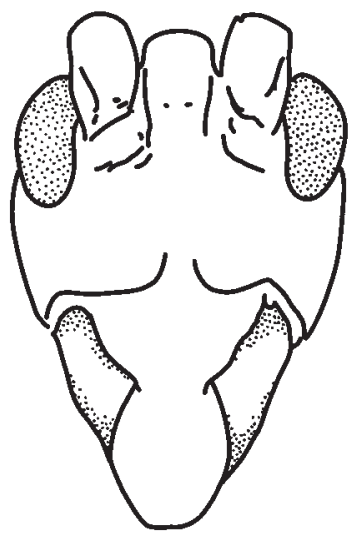

E

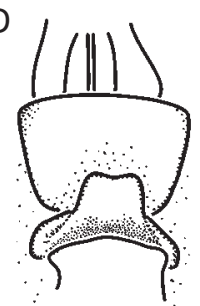

$\mathrm{E}$

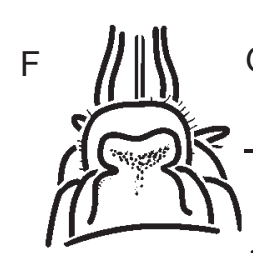

G
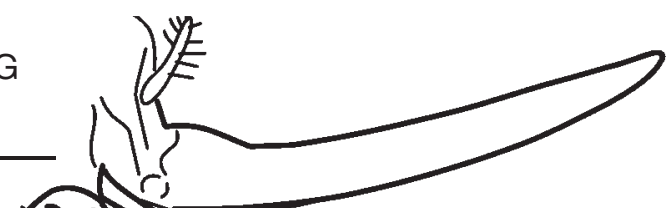

$\mathrm{H}$
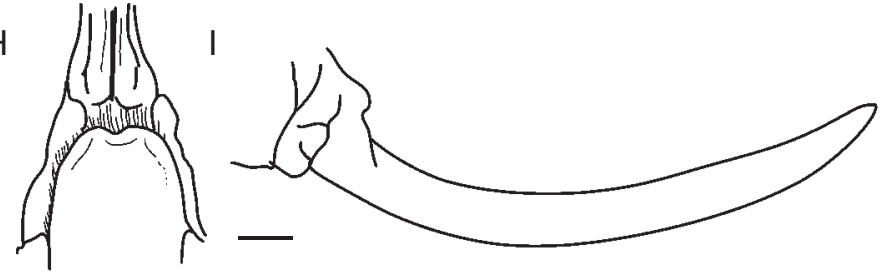

FIG. 6. - Nannogryllacris Karny, 1937: A, K, N. furciventris Karny, 1935, female holotype (NHW); B, N. exigua (Brunner von Wattenwyl, 1888), holotype after Kaltenbach (1968); C, H, I, N. niaoulii (Kaltenbach, 1968), holotype after Kaltenbach (1968); D, E, J, N. novaguineae polygramma (Karny, 1928) (D and J after Karny [1928] and good quality pictures; E, female allotype [ZMB]); F, G, N. heurnii Karny, 1930, after Karny (1930b); A-C, face in frontal view; D, F, H, K, female terminalia in ventral view; E, G, I, left side view of ovipositor; $\mathbf{J}$, ventral view of male terminalia. Scale bars: $1 \mathrm{~mm}$. reduced, not much longer than male styli. Mesosternum and metasternum lobes rounded.

\section{REMARKS}

This genus and the five species belonging to it are omitted in Otte (2000).
C
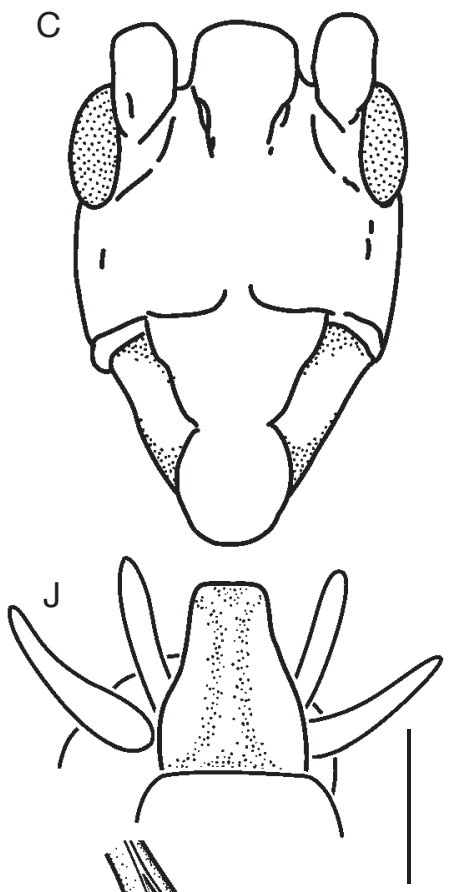

K

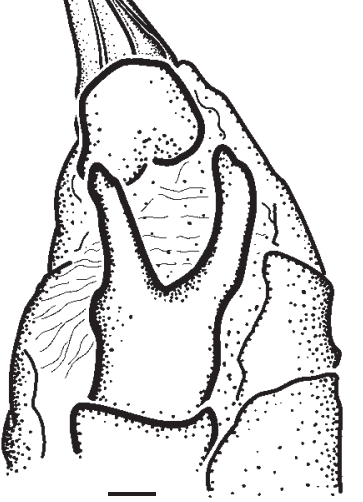

Nannogryllacris niaoulii Kaltenbach, 1968 is often omitted in available databases.

Karny (1937) considered Amphibologryllacris and Nannogryllacris as extremely closely related and gave only colour characters to distinguish them. 
Tentative Key to ADUlt NANNOGRYLLACRIS KARNY, 1937 SPECIES

Abdominal apex is lacking in N. exigua (Brunner von Wattenwyl, 1888).

1. FW with $\mathrm{M}$ not visible on the base, fused with R from the base to the FW proximal third (Fig. 7A); male cerci not longer than styli (Fig. 6J); female SGP preceding sternite with a cuneiform posterior projection (Fig. 6D); ovipositor shorter than FIII .....

N. novaguineae

- FW with $\mathrm{M}$ visible on the base, sometimes lying in contact to $\mathrm{R}$, sometimes anastomosed with R (Fig. 7C-E); male only known in N. niaoulii (Kaltenbach, 1968) without styli; when known, female SGP preceding sternite unmodified or with a lobiform or furciform appendice, not with a cuneiform appendice; ovipositor shorter, as long as, or longer than FIII ........ 2

2. FW with $\mathrm{Cu}$ simple (not furcated, Fig. 7C, E); head without conspicuous ocelli; when known, SGP preceding sternite unmodified; when known, male SGP without styli; when known, ovipositor much (c. $1 / 3)$ longer than TIII ..................................................... 3

- FW with furcated Cu (Fig. 7B, D); head with or without conspicuous ocelli; on unknown; female SGP preceding sternite with a lobiform or a furciform projection; ovipositor at most as long as TIII

3. FW with $4 \mathrm{~A}$ veins (Fig. 7C); frons wide (Fig. 6C); ovipositor $1 / 3$ longer than FIII N. niaoulii

- FW with 5 A veins (Fig. 7E); frons relatively narrower (Fig. 6B); ovipositor unknown N. exigua

4. FW with $\mathrm{Cu}$ at least furcated 3 times (at least 4 terminal branches; Fig. 7B); head with conspicuous ocelli (Fig. 6A); female SGP preceding sternite furciform (Fig. 6K); ovipositor as long as FIII .............................................................................. N. furciventris

- FW with Cu furcated 1 time (2 terminal branches; Fig. 7D); head without conspicuous ocelli; female SGP preceding sternite lobiform (Fig. 6F); ovipositor distinctly shorter than FIII $N$. heurnii

Genus Psilogryllacris Karny, 1937

Psilogryllacris Karny, 1937: 94.

TYPE SPECIES. — Psilogryllacris dalbertisi Karny, 1937.

\section{Psilogryllacris tchancha n. sp.} (Figs 8; 9)

Type Material. - Vanuatu. Sanma Province, Espiritu Santo Isl., Peavot, Mt Nouresororo, 1459'26”S, $166^{\circ} 45^{\prime} 14^{\prime \prime E}, 636 \mathrm{~m}$ alt., forêt de brume, sur plante de sous-bois, nuit, Exped. Santo 2006, 22.X.2006, coll. T. Robillard, o holotype (TR-301, SH-035) (MNHNENSIF2187).

Type LOCality. - Vanuatu, Sanma Province, Espi-

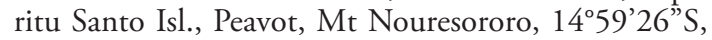
$166^{\circ} 45^{\prime} 14$ ”E, $636 \mathrm{~m}$ alt.

Distribution. - Vanuatu, Sanma Province, Espiritu Santo Isl., Butmas, Tankara plateau.
Etymology. - After Tchancha $\left[\mathrm{t} \int \mathrm{an} \int \mathrm{a}\right]$, the name given in Peavot to Gryllacridids.

HABITAT AND LIFE HISTORY TRAITS. — Not documented.

DiagnOSIs. - Compared to other Psilogryllacris species. Body length within genus range; limbs short for the genus: FIII: $12.2 \mathrm{~mm}$ (12.3-13.8 $\mathrm{mm}$ in P. dalbertisi (Griffini, 1909); similar for P. omissa Karny, 1937 [Karny 1925, 1931]; $13.5 \mathrm{~mm}$ in P. rugifrons (Karny, 1931); $15.4 \mathrm{~mm}$ in P. maculiventris (Karny, 1931)); FW short: $16.4 \mathrm{~mm}$ (28.5-35 $\mathrm{mm}$ in P. dalbertisi; similar for P. omissa [Karny 1925, 1931]; $32.3 \mathrm{~mm}$ in P. rugifrons; $34.7 \mathrm{~mm}$ in P. maculiventris).

Head rounded in frontal view (Fig. 8A; not rounded in $P$. omissa, $P$. dalbertisi and $P$. rugifrons); wider than pronotum in dorsal view (not wider than pronotum in $P$. omissa and $P$. dalbertisi; not or inconspicuously brighter in P. rugifrons); median ocellus inconspicuous (clearly distinct in other Psilogryllacris species). FW not exceeding the body posterior apex (much longer in all species of the genus).

Psilogryllacris tchancha $\mathrm{n}$. sp. differs from the superficially 
close Papuogryllacris adoxa (Karny, 1928) by: $\mathrm{M}$ and $\mathrm{Cu}$ not fused (M and Cu fused on FW basal third); R strongly furcated ( 4 bifurcations in Psilogryllacris tchancha n. sp. vs. 2 in Papuogryllacris adoxa); female SGP triangular with a minute emargination (rounded with a wide emargination in Papuogryllacris adoxa).

Measurements. - See Table 3.

\section{DESCRIPTION}

In addition to generic characters. Body length within the range of the genus. Head (Fig. 8A): rounded, oboval in frontal view, distinctly broader than the thorax; fastigium frontis distinctly wider than the scapus; face maximal width (in frontal view, below the eyes) 3 times (min: 3.5; max: 4.0; holotype: 4.0; allotype: 3.9 ) as wide as the fastigium frontis (measured above antennal sockets); median and lateral ocelli inconspicuous.

Thorax. Pronotum: maximal width 1.2 times wider than maximal length; anterior margin weakly convex (in dorsal view), arched (in frontal view); posterior margin almost strait, with a weak median concavity (in dorsal view), slightly arched (in posterior view); anterior sulcus deep on the lateral lobes and distinct on the discus; posterior sulcus very shallow on the discus; both sulci are converging on the lateral lobes; prozona (anterior to anterior sulcus) elevated; metazona (posterior to posterior sulcus) narrower than the anterior part of the pronotum.

Wings. FW (Fig. 9A, B): with 3 or 4 precostal veins; $R$ divided in 5 or 6 veins ( 4 or 5 bifurcations); $\mathrm{M}$ contacting $\mathrm{R}$ at the FW base, $\mathrm{M}$ simple (not divided) on the right FW, divided and refused on the left FW apex; Cu simple on the left FW, divided in 3 veins ( 2 bifurcations); 6 A veins.

Legs. Forelegs and mid legs with the usual spurs formula (4 pairs of subapical + 1 pair of apical spurs ventrally, and one single apical spur on TII dorsally); subapical spurs distinctly reduced (Fig. 8B, C; distinctly shorter than the tibia width). Hind legs: femora 2.9 times as long as wide (Fig. 8F); FIII with 2 or 3 ventral inner spines; FIII with 7 or 8 spines; TIII with 5 dorsal inner spines; with 4 or 5 ventral outer spines.

\section{SEXUAL DIMORPHISM}

Male

Unknown.
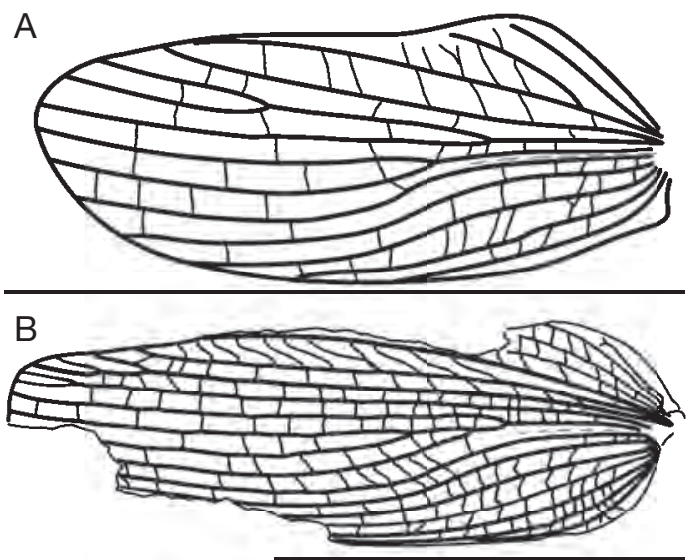

C
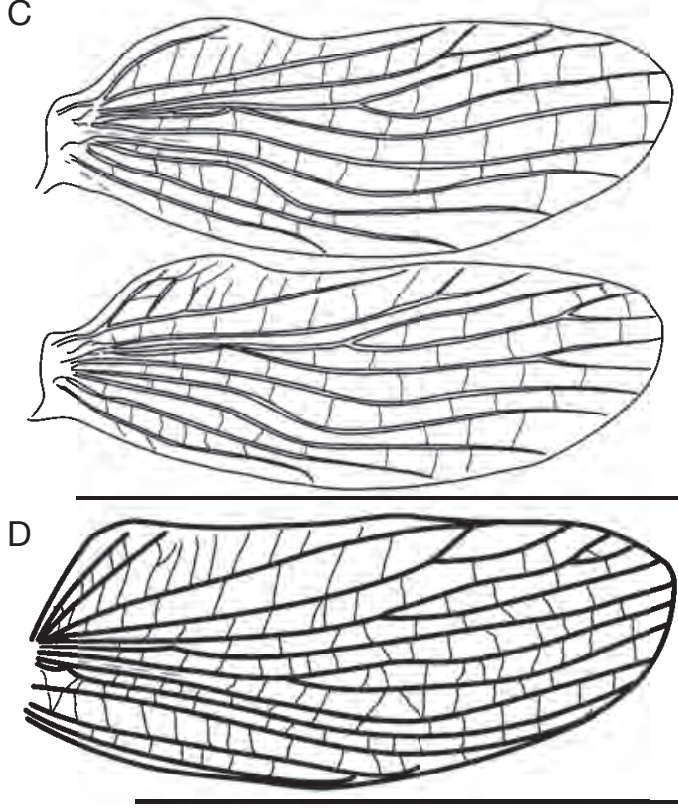

$\mathrm{E}$

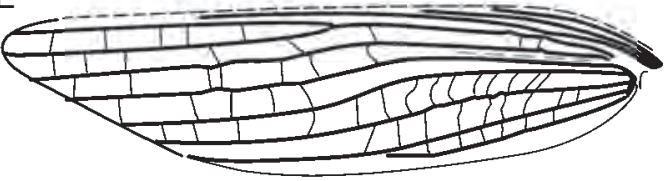

FlG. 7. - Nannogryllacris Karny, 1937 forewing: A, N. novaguineae polygramma (Karny, 1928) left forewing after Karny (1928); B, N. furciventris Karny, 1935, female holotype left forewing (NHW); C, N. niaoulii (Kaltenbach, 1968), holotype and paratype, right forewing after Kaltenbach (1968); D, N. heurnii Karny, 1930, holotype right forewing, after Karny (1930b); E, N. exigua (Brunner von Wattenwyl, 1888), holotype, left forewing. The grey dotted lines correspond to the claval fold. Scale bars: $10 \mathrm{~mm}$. 


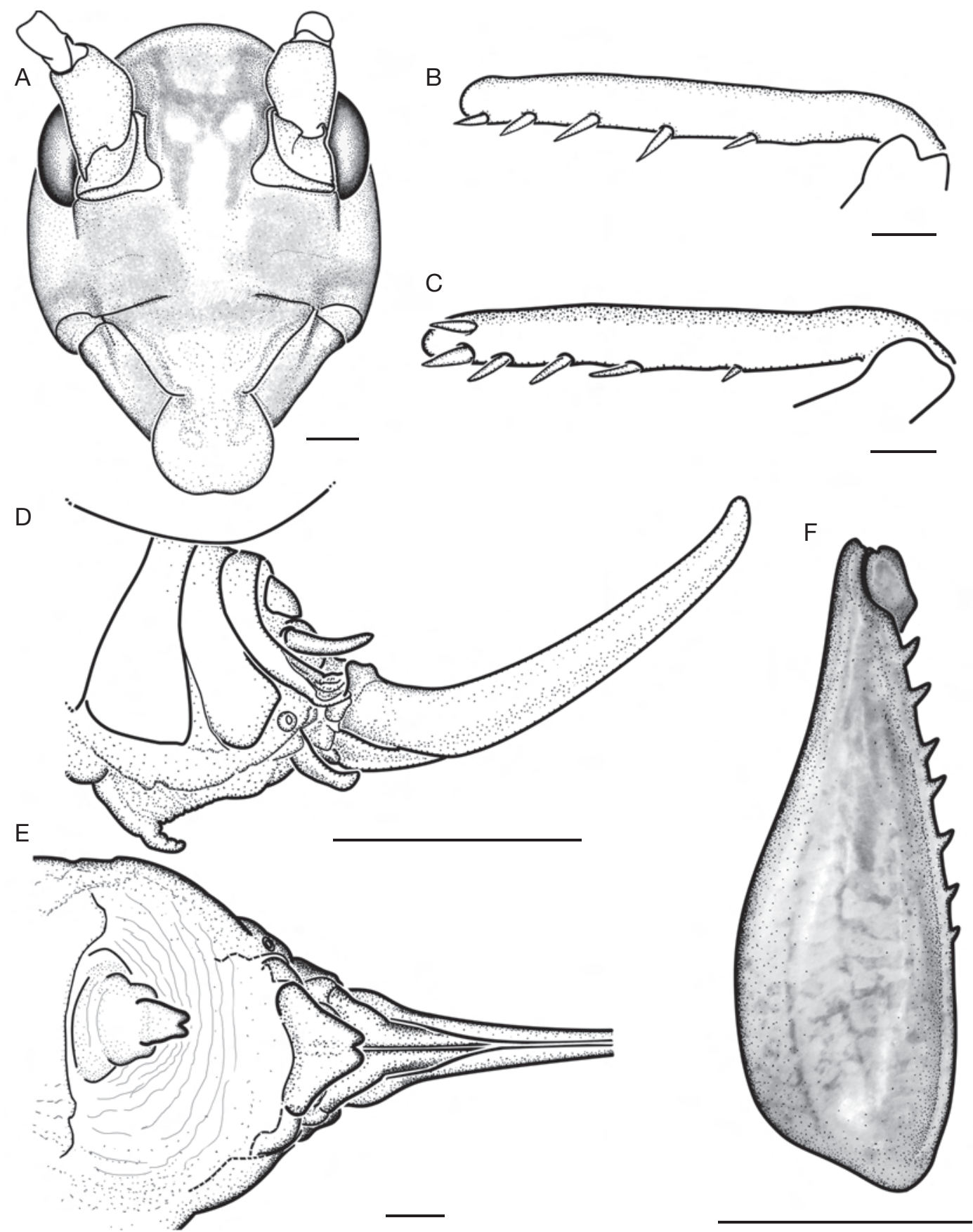

FIG. 8. - Psilogryllacris tchancha n. sp., female holotype: A, face in frontal view; B, external view of left tibia I (note the short proximal spurs); C, posterior view of left tibia II (note the short proximal spurs); D, left side view of female terminalia; E, ventral view of female terminalia; F, lateral view of left femur III. Scale bars: A, B, C, E, $1 \mathrm{~mm} ; \mathrm{D}, \mathrm{F}, 5 \mathrm{~mm}$. 
TABle 3. - Measurements of Psilogryllacris tchancha n. sp. Abbreviations: see text. Notes: 1, frontal view base of scapus level; $\mathbf{2}, \mathbf{4}$, depends on the preservation; $\mathbf{3}$, depends on the wing arching.

\begin{tabular}{|c|c|c|c|c|c|c|c|c|c|c|c|c|c|c|c|c|c|}
\hline & \multirow{2}{*}{$\begin{array}{c}\text { Bd } \\
\mathbf{L}\end{array}$} & \multirow{2}{*}{$\begin{array}{c}\text { Hd } \\
\text { W } \\
\text { max. }\end{array}$} & \multirow{2}{*}{$\begin{array}{c}\text { FFr1 } \\
\text { W }\end{array}$} & \multicolumn{2}{|c|}{ Prn } & \multicolumn{2}{|c|}{ FW } & \multirow{2}{*}{$\begin{array}{l}\text { TI } \\
\text { L }\end{array}$} & \multirow{2}{*}{$\begin{array}{l}\text { TII } \\
\text { L }\end{array}$} & \multirow{2}{*}{$\begin{array}{c}\text { TIII } \\
\mathbf{L}\end{array}$} & \multirow{2}{*}{$\begin{array}{l}\text { FI } \\
\text { L }\end{array}$} & \multirow{2}{*}{$\begin{array}{c}\text { FII } \\
\text { L }\end{array}$} & \multicolumn{2}{|c|}{ FIII } & \multicolumn{2}{|c|}{ SGP } & \multirow{2}{*}{$\begin{array}{c}\text { Ovs } \\
\text { L }\end{array}$} \\
\hline & & & & L & $\mathbf{W}^{2}$ & L & $\mathbf{W}^{3}$ & & & & & & L & w & & & \\
\hline 700 typ & 24.7 & 6.5 & 2.1 & 5.4 & 6.2 & 16.4 & 6.0 & 7.3 & 7.6 & 11.7 & 6.2 & 6.4 & 11.7 & 4.1 & 1.3 & 1.6 & 9.5 \\
\hline
\end{tabular}
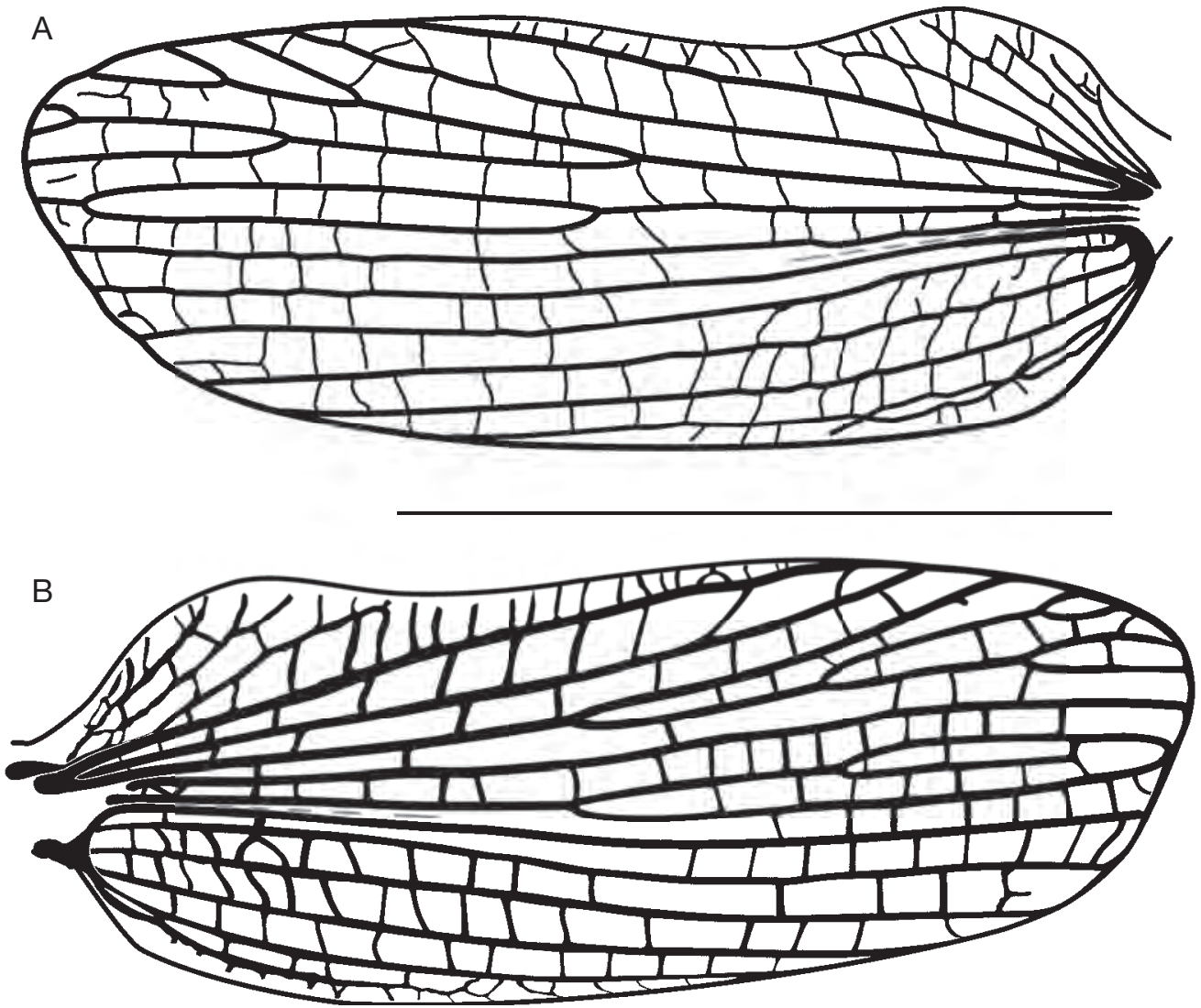

FIG. 9. - Psilogryllacris tchancha n. sp., female holotype forewing: A, left forewing; B, right forewing. Note the difference in venation. The grey dotted lines correspond to the claval fold. Scale bar: $10 \mathrm{~mm}$.

\section{Female}

Sternite preceding the SGP (VII): bearing a process on the anterior margin of the sternite, directed backwards; longer than the SGP length (Fig. 8D, $\mathrm{E})$; the base of the process is weakly sclerotized; the apex of the process is sclerotized, forms a plate with moderately converging borders, and with a triangular notch on the apex; the subgenital plate is wider than longer, triangular, with a triangular notch on the apex.

\section{Colour}

The general colour is brown, without strong black patterns, except on the fastigium. Head: face with 
a creamish median vertical line from the clypeus to the middle of the fastigium frontis, with poorly defined borders; clypeus cream; antennal sockets cream, eyes posteriorly surrounded by a light band; fastigium verticis borders with black lines joined on the fastigium frontis by an horizontal black line. Pronotum with indistinct pale and dark patterns. FW veins and veinlets brown, darker than the cells. HW hyaline, except the most anterior apical cells coloured as the FW cells. Legs without black patterns; hind leg with creamish and brown longitudinal patterns on the external side.

GENERIC ASSIGNATION OF P. TCHANCHA N. SP. Karny (1937) grouped under this genus four species having in particular: long wings; particularly short ventral subapical spurs on TI and TII; the usual subapical spurs number ( 4 in addition to apical spurs) on TI, and usually 4 (seldom 3 ) spurs on TII.

Apart from its shorter wings, P. tchancha n. sp. exactly corresponds to Karny's (1937) definition of this genus, and we therefore described it under Psilogryllacris.

Papuogryllacris Griffini, 1909 is defined in particular as having long wings too, but only 3 subapical spurs of normal size on TI and TII. Nevertheless, P. adoxa (Karny, 1928) has distinctly reduced TI and TII subapical spurs (3 on TI and 2 on TII) and distinctly short wings and body size for the genus. For these reasons, Karny (1928) raised doubts on the affinities of $P$. adoxa to Papuogryllacris taxon (at this time considered as a subgenus). Interestingly, $P$. adoxa superficially resembles to Psilogryllacris tchancha n. sp. (size, head shape and width, short wings, short TI-TII subapical spurs, short and thick TIII, emarginated female SGP, short cerci, shape and ovipositor length). Papuogryllacris adoxa might therefore be related to Psilogryllacris tchancha n. sp., but male characters of both species and a thorough redefinition of Psilogryllacris and Papuogryllacris would be required to define whether these two species should be grouped under a new genus. Importantly, Karny (1928) described a P. adoxa variety (var. tenuispina) with long subapical spurs suggesting that spur length might not be stable and should be considered with caution (moreover, in some genera, given species are also displaying a spur reduction but to a lesser degree, it is the case for Nannogryllacris heurnii Karny, 1930 having reduced subapical spurs in TII).

Family TettigonidDae Krauss, 1902

Genus Ityocephala Redtenbacher, 1892

Ityocephala Redtenbacher, 1892: 191, 219.

TyPE SPECIES. - Ityocephala falcata Redtenbacher, 1892.

Diagnosis. - See Caudell (1916).

Ityocephala nigrostrigata (Walker, 1871)

Pseudophyllus nigrostrigata Walker, 1871: 44.

Ityocephala nigrostrigata - Bruner 1916: 162.

Ityocephala falcata Redtenbacher, 1892: 220 (type locality: South western Pacific, Tonga, Vava’u. Not Fiji). — Kirby 1906: 366

Type Material. - Vavou, Pacific Ocean, $q$ holotype (BMNH). Pictures examined.

Other material. - Type material of I. falcata: Fiji. Dämel, Coll. Br[unner] von W[attenwyl]; Ityocephala falcata [manuscript] det. Redtenbacher [printed] $q$ (NHW). Pictures examined.

TyPe LOCALITY. — South western Pacific, Fiji.

\section{REMARKS}

The synonymy of $I$. falcata with $I$. nigrostrigata is often omitted in the literature. Nevertheless, it is not clear whether both female holotypes are really belonging to the same species: the ventral margin of I. nigrostrigata ovipositor is regularly rounded, except a flat area on the middle; the ventral margin of I. falcata holotype ovipositor is strait on the base and angularly up curved after the base (but this difference could be due to a bad preservation of ovipositor ventral valves of $I$. falcata holotype). In addition, I. nigrostrigata and I. falcata holotypes are from distinct South western Pacific archipelagos: the type locality of I. nigrostrigata is "Vavou" (Walker 1871) 
TABLE 4. - Measurements of Ityocephala francoisi Bolívar, 1903. Abbreviations: see text. Note: 1, depends on the preservation.

\begin{tabular}{|c|c|c|c|c|c|c|c|c|c|c|c|c|c|c|c|c|c|c|c|}
\hline & \multirow{2}{*}{$\begin{array}{c}\text { Bd } \\
\text { L }\end{array}$} & \multirow{2}{*}{$\begin{array}{c}\text { Hd } \\
\text { W } \\
\text { max. }\end{array}$} & \multirow{2}{*}{$\begin{array}{l}\text { Vtx } \\
\text { W }\end{array}$} & \multicolumn{3}{|c|}{ Prn } & \multicolumn{2}{|c|}{ FW } & \multirow{2}{*}{$\begin{array}{l}\text { A1 } \\
\text { L }\end{array}$} & \multirow{2}{*}{$\begin{array}{l}\text { TI } \\
\mathrm{L}\end{array}$} & \multirow{2}{*}{$\begin{array}{c}\text { TII } \\
\text { L }\end{array}$} & \multirow{2}{*}{$\begin{array}{c}\text { TIII } \\
\mathbf{L}\end{array}$} & \multirow{2}{*}{$\begin{array}{l}\text { FI } \\
\mathbf{L}\end{array}$} & \multirow{2}{*}{$\begin{array}{c}\text { FII } \\
\text { L }\end{array}$} & \multicolumn{2}{|c|}{ FIII } & \multicolumn{2}{|c|}{ SGP } & \multirow{2}{*}{$\begin{array}{c}\text { Ovs } \\
\mathrm{L}\end{array}$} \\
\hline & & & & $\mathbf{L}$ & $\underset{\max }{\mathbf{W}}$ & $\underset{\max }{\mathbf{H}}$ & $\mathbf{L}$ & $\underset{\text { mid. }}{\mathbf{W}}$ & & & & & & & $\mathbf{L}$ & $\underset{\max }{W}$ & $\mathbf{L}$ & $\begin{array}{l}\text { W1 } \\
\text { base }\end{array}$ & \\
\hline$\sigma^{7}$ holotype & 25.0 & & & 5.8 & & & 40.0 & & & & & & & & 19.0 & & & & - \\
\hline $\begin{array}{c}\mathrm{o}^{7} \mathrm{n}=6 \\
\min . \\
\max .\end{array}$ & $\begin{array}{l}23.2 \\
21.5 \\
25.0\end{array}$ & $\begin{array}{l}4.2 \\
4.0 \\
4.2\end{array}$ & $\begin{array}{l}1.8 \\
1.7 \\
1.8 \\
\end{array}$ & $\begin{array}{l}5.7 \\
5.3 \\
5.9\end{array}$ & $\begin{array}{l}4.8 \\
4.6 \\
4.9 \\
\end{array}$ & $\begin{array}{l}3.8 \\
3.6 \\
4.1\end{array}$ & $\begin{array}{l}38.4 \\
36.5 \\
40.1 \\
\end{array}$ & $\begin{array}{l}10.9 \\
10.5 \\
11.6 \\
\end{array}$ & $\begin{array}{l}2.3 \\
2.2 \\
2.4 \\
\end{array}$ & $\begin{array}{l}7.0 \\
6.8 \\
7.3 \\
\end{array}$ & $\begin{array}{l}8.1 \\
7.4 \\
8.4 \\
\end{array}$ & $\begin{array}{l}18.5 \\
17.6 \\
19.4 \\
\end{array}$ & $\begin{array}{l}6.6 \\
6.3 \\
7.0 \\
\end{array}$ & $\begin{array}{l}7.9 \\
7.5 \\
8.4\end{array}$ & $\begin{array}{l}18.7 \\
17.7 \\
19.5 \\
\end{array}$ & $\begin{array}{l}2.2 \\
2.2 \\
2.3 \\
\end{array}$ & $\begin{array}{l}4.4 \\
4.1 \\
4.6\end{array}$ & $\begin{array}{l}1.3 \\
1.0 \\
1.7\end{array}$ & $\begin{array}{l}- \\
- \\
-\end{array}$ \\
\hline $\begin{array}{c}9 \mathrm{n}=5 \\
\min . \\
\max .\end{array}$ & $\begin{array}{l}31.8 \\
29.9 \\
33.3\end{array}$ & $\begin{array}{l}5.3 \\
5.0 \\
5.5\end{array}$ & $\begin{array}{l}2.4 \\
2.2 \\
2.5\end{array}$ & $\begin{array}{l}6.7 \\
6.4 \\
7.0\end{array}$ & $\begin{array}{l}6.2 \\
5.6 \\
6.5\end{array}$ & $\begin{array}{l}4.8 \\
4.5 \\
5.0\end{array}$ & $\begin{array}{l}46.1 \\
44.9 \\
47.1\end{array}$ & $\begin{array}{l}14.3 \\
13.3 \\
15.0\end{array}$ & $\begin{array}{l}- \\
- \\
-\end{array}$ & $\begin{array}{l}8.3 \\
8.1 \\
8.4\end{array}$ & $\begin{array}{r}9.6 \\
8.7 \\
10.1\end{array}$ & $\begin{array}{l}22.0 \\
20.0 \\
23.9\end{array}$ & $\begin{array}{l}7.6 \\
7.3 \\
7.8\end{array}$ & $\begin{array}{l}9.3 \\
8.7 \\
9.5\end{array}$ & $\begin{array}{l}21.7 \\
20.5 \\
22.4\end{array}$ & $\begin{array}{l}2.8 \\
2.7 \\
3.0\end{array}$ & $\begin{array}{l}1.9 \\
1.6 \\
2.1\end{array}$ & $\begin{array}{l}1.9 \\
1.5 \\
2.4\end{array}$ & $\begin{array}{r}9.7 \\
9.3 \\
10.0\end{array}$ \\
\hline
\end{tabular}

now named Vava'u, a group of islands belonging to the Tonga archipelago and not Fiji as stated in many databases; the type locality of I. falcata is Fiji (Redtenbacher, 1892). At this stage, and as I have not directly examined I. falcata and I. nigrostrigata holotypes and as males from Tonga and Fiji are unknown, I prefer to keep the synonymy of $I$. falcata under I. nigrostrigata.

\section{Ityocephala francoisi Bolívar, 1903}

(Figs 10;15A)

\section{Ityocephala francoisi Bolívar, 1903: 171.}

Type Material. - [Vanuatu. Sanma Province, Espiritu Santo Isl.], N. Hébrid. Santo (Fr.) [Manuscript]; Ityocephala Francoisi Bol. [Manuscript]; Holotipo [printed red label]; MNCN, Cat. Tipos No 759 [printed red label];

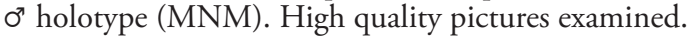

Type locality. - Vanuatu, Sanma Province, Espiritu Santo Isl.

OTHER MATERial EXAMined. - Vanuatu. (5 $0^{\circ} 0^{\prime \prime}, 5$ ○ ), Sanma Province, Espiritu Santo Isl., Butmas, forêt sur plateau de Tankara, bord de chemin, 15²1'56”S, $166^{\circ} 59^{\prime} 04$ " E, $600 \mathrm{~m}$ alt., sur plante $3 \mathrm{~m}$ de haut, nuit, Exped. Santo 2006, 13.X.2006, coll. S. Hugel, 1 \% (SH-044) (MNHN-ENSIF2196).

Peavot, forêt secondaire, 1459'37'S, 16647'04'E, $38 \mathrm{~m}$ alt., ancien jardin, rive $S$ de la rivière, rive, nuit, Exped. Santo 2006, 20.X.2006, coll. S. Hugel, 1 O' (SH-037) (MNHN-ENSIF2189). - Same locality, date and collector, terrasse 2, sur plante $2 \mathrm{~m}$ de haut, nuit, 1 ( $\mathrm{SH}-042$ ) (MNHN-ENSIF2194). - Same locality and collector, terrasse 2 , sur plante $5 \mathrm{~m}$ de haut, nuit, enregistrement, 21.X.2006, 1 ơ (SH-036) (MNHN-ENSIF2188). Same locality and collector, nuit, 21.X.2006, 1 \%
(SH-040) (MNHN-ENSIF2192). - Same locality and collector, nuit, 23.X.2006, $10^{7}$ (SH-039) (MNHNENSIF2191). - Same locality and collector, nuit, 23.X.2006, 1 (SH-041) (MNHN-ENSIF2193).

Big Bay, Matantas, Vatthé Lodge, forêt autour de la grotte, $15^{\circ} 10^{\prime} 48^{\prime \prime S}, 166^{\circ} 57^{\prime} 27^{\prime \prime} \mathrm{E}, 30 \mathrm{~m}$ alt., sous-bois, nuit, Exped. Santo 2006, 27.X.2006, coll. S. Hugel, $10^{7}$ (SH-038) (MNHN-ENSIF2190). - Same locality and collector, nuit, 27.X.2006, 1 ○ (SH-043), 1 o' (SH-045) (MNHN-ENSIF2195, 2197).

Distribution. - Vanuatu, Espiritu Santo.

HABITAT AND LIFE HISTORY TRAITS. - All I. francoisi specimens have been found in relatively humid non coastal forests, in both preserved or slightly anthropized areas. Ityocephala francoisi seems to be strictly active during night hours. Adults seem mostly to stay on tree top, even on small trees. Females are sometimes observed in lower strata, and two specimens have been observed in oviposition in dead sections (diameter $3 \mathrm{~cm}$, at 2-3 m) of living trees.

Diagnosis (TENTATIVE, FEMALE ONLY). - Ovipositor ventral valves strait on the base (regularly curved in I. nigrostrigata female holotype); basally dorsal valves (Fig. 10G) less than twice as high as ventral valves (the base of ventral valves is much narrower in Ityocephala specimens from Tonga and Fiji).

Measurements. - See Table 4.

\section{REDESCRIPTION}

Head (Fig. 10A, B). Less wide than pronotum; face, genae and occiput with minute depression giving a granulose aspect; occiput relatively flattened; eyes rounded, projecting; in dorsal view: fastigium flat, not projecting, truncated, 0.44 (min: 0.41 ; max: 0.47 ) times wider than head maximal width (eyes not included), 1.6 (min: 1.5; max: 1.7) times wider 
than eye maximal diameter, with a median incision; in frontal view, fastigium forming two trapezes separated by a vertical sulcus and separated from the frons by an arched sulcus; median ocellus weakly distinct, less wide than half inter scrobus width; frons/genae limit without carina; scapus less wide than eyes (frontal view), without spine.

Thorax. Pronotum (Fig. 10E): strongly granulose; 1.1 (min: 1.0; $\max : 1.2$ ) times longer than wide (maximal width); discus anterior margin moderately convex, posterior margin rounded (convex) with a minute emargination on the middle; prozona and mesozona weakly arched, metazona flattened; discus anterior and posterior sulci well distinct, both sulci deep and converging on lateral lobes; without median and lateral carinae; lateral lobe ventral margin with a longitudinal bulging callosity; lateral lobe posterior ventral angle squared. Prosternum with usual paired spines: long, diverging, with blunt apex; mesosternum and metasternum with elevated lateral lobes pointing posteriorly.

Wings. FW opaque, with dense and thin reticulation; wider on the apex than on the base; apex obliquely truncated; HW inconspicuously exceeding the FW.

Legs. TI with uncovered oval inner and outer tympana; moderately inflated on tympanal area; with 2 dorsal carinae, more rounded ventrally; with 2 ventral and 1 dorsal apical spurs on each side; with 7-9 inner preapical spurs; with 6-8 outer preapical spurs, without dorsal spurs or spines. FI with a minute spine on each knee lobe; with 2 ventral carinae; with 1-5 (usually 2 or 3) spines on the inner ventral margin; without spines on the ventral outer margin. TII squared in cross section; with 2 ventral and 1 dorsal apical spurs on each side; with 7-11 (usually 8-10) ventral anterior preapical spurs; with 6-8 ventral posterior spurs; rarely (2/10 specimens) with one minute dorsal posterior basal spur. FII with a minute spine on each knee lobe; with 2 ventral carinae; rounded dorsally; with 4-7 spines on the ventral anterior margin; without spines on the ventral posterior margin. TIII with 3 ventral and 1 dorsal apical spurs on each side; squared in cross section; with 9-12 spurs on the inner ventral carina; 13-17 spurs on the ventral outer carina; 1419 spurs on the inner dorsal carina; 13-19 spurs on the outer dorsal carina. FIII slender, elongated 8.0 (min: 7.2; max: 8.7) times longer than FIII maximal width; with on spine on each knee lobe; with 2 ventral carinae; with 12-18 (usually 14 or 15) spines on the inner ventral carina; with 7-14 spines on the outer ventral carina.

\section{Colour}

General coloration green (yellowish in dead specimens). Pronotum sulci and FW veins yellowish; HW hyaline except anterior field; ventral and internal area of $\mathrm{F}$ from yellow to orange.

\section{VARIATIONS}

Some specimens are displaying, to different degrees, black on: bulging callosity of pronotum lateral lobe ventral margin; TI and TII apex; FI and FII ventral area; FI and FII knee; TIII ventral margins; FIII ventral margins.

\section{SEXUAL DIMORPHISM}

Males are significantly smaller than females. Female body length $40 \%$ longer than male body length (23 mm vs. $32 \mathrm{~mm}$ ); female FW about 20\% longer than male FW. Females have usually less black patterns than males.

\section{Male}

Singing apparatus: left FW anal field as opaque and with the same dense reticulation than the whole FW; the file vein (A1) is well distinct (dorsal view); file with 73 (min: 70; max 76) lamellar teeth (Fig. 10H). Right FW tympanum 1.76 (min: 1.74; max: 1.78) times as long as wide (Fig. 10D). Terminalia: tergite X (last) with a minute posterior emargination; epiproct acutely triangular, with a blunt apex; cerci with a minute apical teeth bent inwards. SGP without styli; elongated: $c .3$ times longer than wide (depending on the specimen preservation); with rounded lateral lobes on the base; after this rounded base, with sub parallel sides; apex with a tongue-shaped emargination 0.20 (min: 0.18 ; max: 0.22 ) times as deep as the SGP length; SGP separated by emargination on two apical lobes with rounded apex; apex slightly ladle-shaped (Fig. 10C).

\section{Female}

SGP as wide as long (min: 0.83; max: 1.19); rounded with a minute rounded apical emargination 

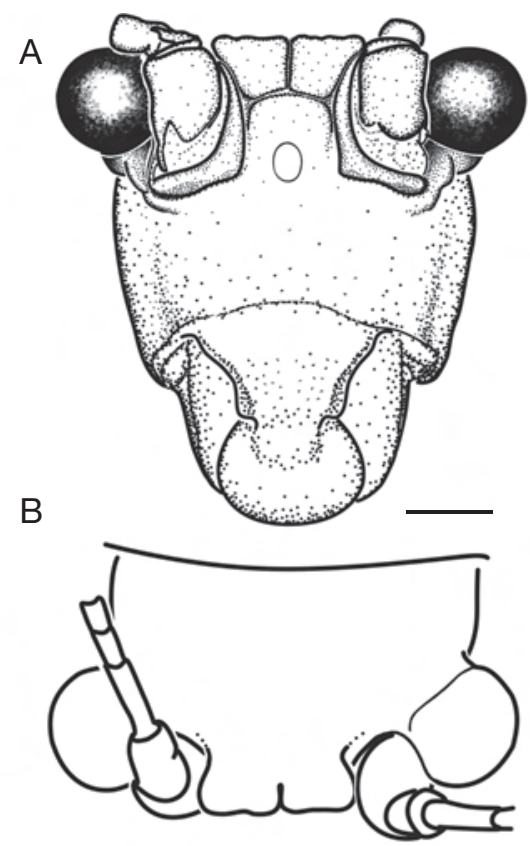

C
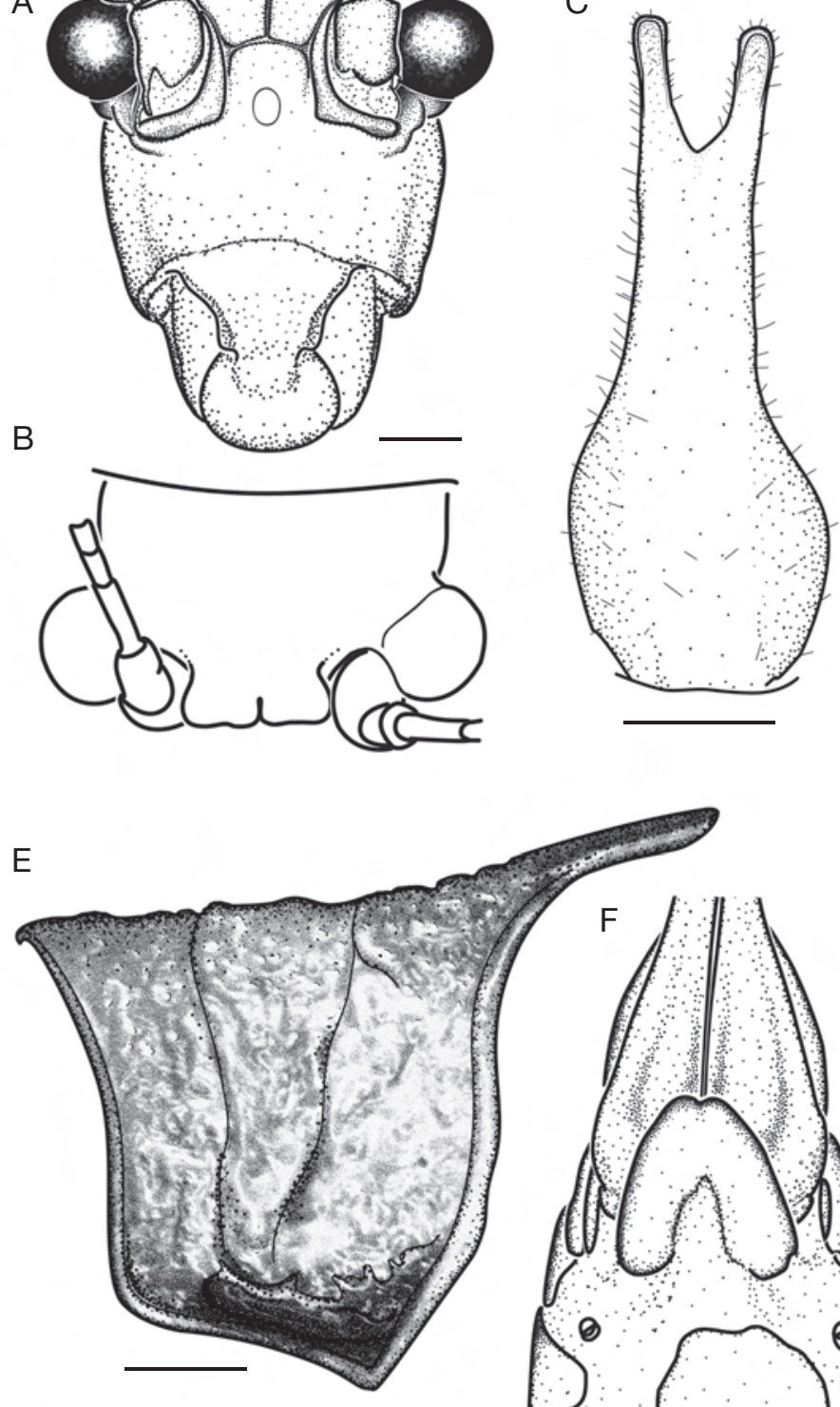

$\mathrm{H}$
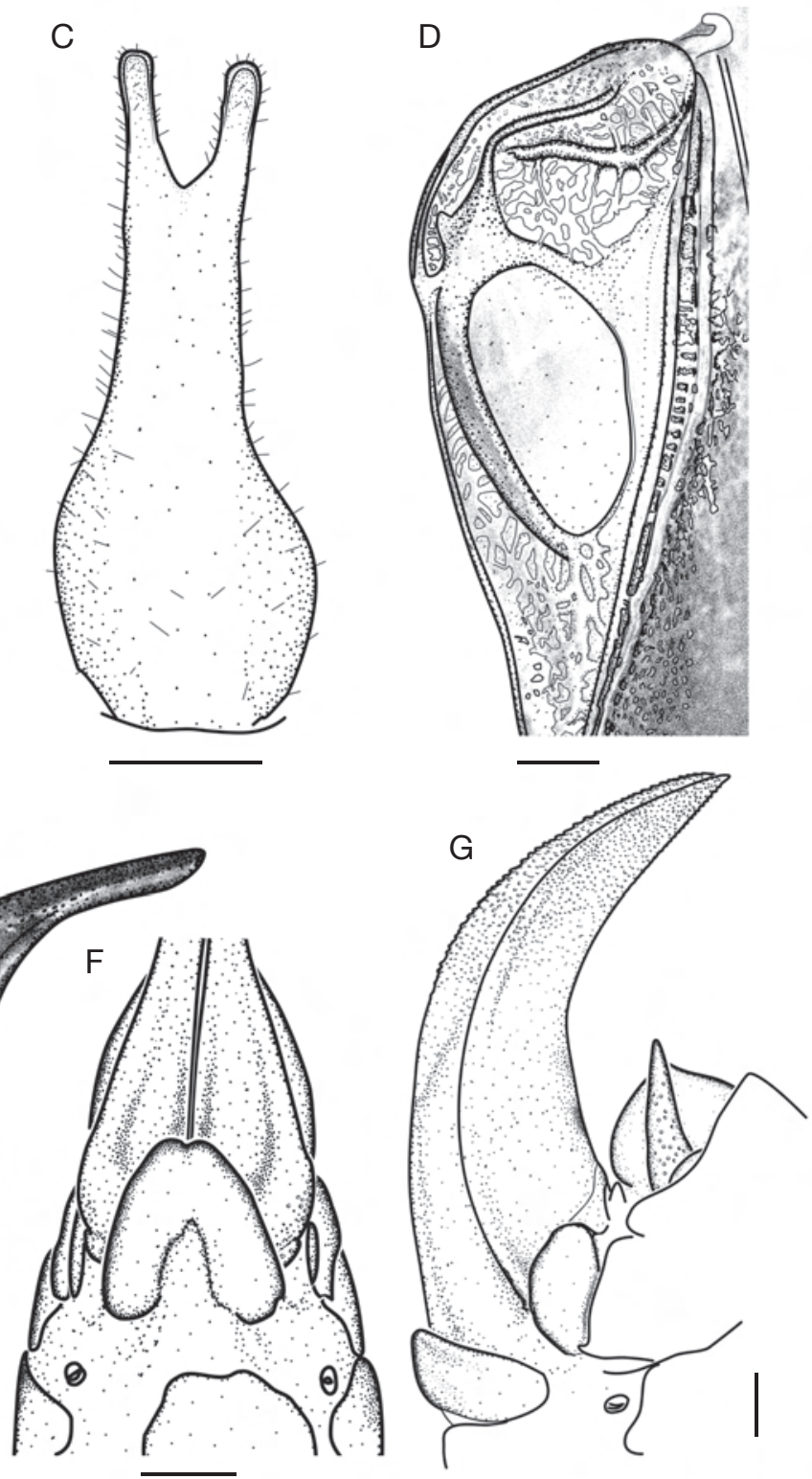

H

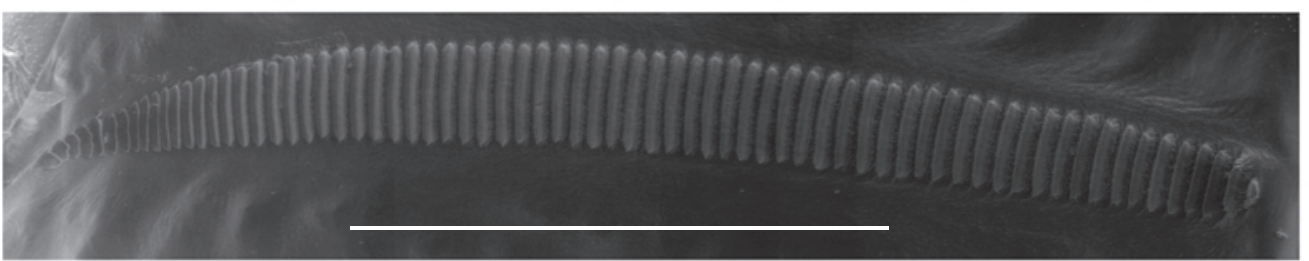

FIG. 10. - Ityocephala francoisi Bolívar, 1903: A, male face in frontal view; B, male vertex and occiput in dorsal view; C, male subgenital plate in ventral view; D, male right forewing anal field in dorsal view; $\mathbf{E}$, male pronotum in left side view; $\mathbf{F}$, female terminalia in ventral view; G, female ovipositor in right side view; H, SEM picture of male file. Scale bars: $1 \mathrm{~mm}$. 

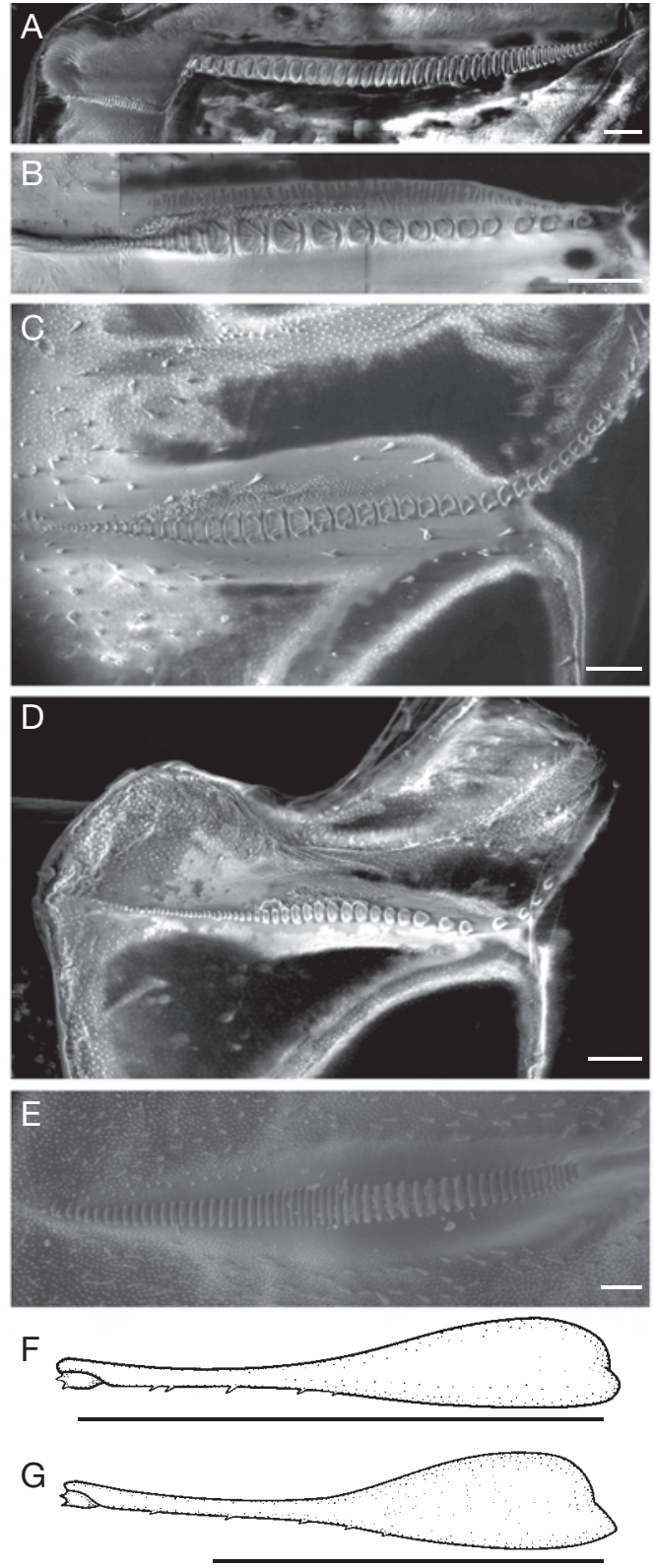

$\mathrm{H}$

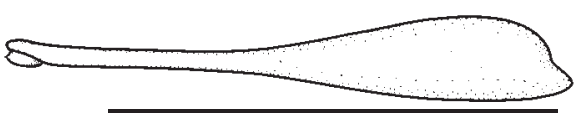

FIG. 11. - A-E, SEM pictures of stridulatory files; F-H, right femur III in side views; A, Phaneroptera gracilis Burmeister, 1838; B, H, Conocephalus upoluensis (Karny, 1907); C, G, C. semivittatus vittatus (Redtenbacher, 1891); D, F, C. oceanicus (Le Guillou, 1841); E, Pseudorhynchus lessonii Serville, 1838. Scale bars: A-E, $100 \mu \mathrm{m} ; \mathrm{F}-\mathrm{H}, 10 \mathrm{~mm}$.
(Fig. 10F). Ovipositor strait on the base and strongly upcurved after mid length (particularly the dorsal margin); with denticulations in the curved section of ventral margin and minute denticulations in the apex of dorsal margin; apex pointing (Fig. 10I).

\section{Calling SONG (FIG. 15A)}

Males call during night hours, on tree top (usually above $3 \mathrm{~m}$ ). Several males are usually singing alternatively. One male has been recorded in the field ( $\mathrm{SH}-036$, MNHN-ENSIF2188). At $26^{\circ} \mathrm{C}$, the call of this species consists of irregular widely spaced (every $32.2 \pm 16.7 \mathrm{~s}$; min: 8.2; max: 96.3) echemes. Individual echemes last $443.8 \pm 21.3 \mathrm{~ms}$ (min: 369.5 ; $\max : 488.3$ ) and consists of 5 or 6 syllables. The calling frequency first harmonic peaks between $9.8-13.0 \mathrm{kHz}$.

\section{Genus Phaneroptera Serville, 1831}

\section{Phaneroptera gracilis Burmeister, 1838}

(Figs 11A; 15B, C)

\section{Phaneroptera gracilis Burmeister, 1838: 690.}

TyPe MATERIAL. - Gracilis Java. MB [manuscript]; probably type of Phaneroptera gracilis Burmeister, 1838 det. S. Ingrisch 2001 [printed]; DORSA, ATphagraS01 [printed], O syntype (MLUH). Not examined. - Gracilis Java. MB [manuscript]; probably type of Phaneroptera gracilis Burmeister, 1838 det. S. Ingrisch 2001 [printed]; DORSA, ATphagraS01 [printed], ơ syntype (MLUH). Not examined.

TyPe LOCALITY. - Tropical Asia, Malesia, Java.

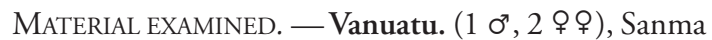
Province, Espiritu Santo Isl., Luganville, site du CTRAV, $15^{\circ} 27^{\prime} 00^{\prime \prime S}, 167^{\circ} 12^{\prime} 26^{\prime} \mathrm{E}, 10 \mathrm{~m}$ alt., zone herbacée, nuit, Exped. Santo 2006, 12.X.2006, coll. T. Robillard, 1 q (SH-046) (MNHN-ENSIF2198). - Same locality, sur graminées $80 \mathrm{~cm}$ de haut, Exped. Santo 2006, 29.X.2006, coll. S. Hugel, 1 \& (SH-047) (MNHN-ENSIF2199). Same locality, sur graminées $80 \mathrm{~cm}$ de haut, enregistré, Exped. Santo 2006, 29.X.2006, coll. S. Hugel, ơ (SH-048) (MNHN-ENSIF2200).

DisTRIBUTION. - Phaneroptera gracilis is widely distributed in the World tropical areas (Ragge 1956). To our knowledge, this species is recorded for the first time in Vanuatu. This observation constitutes the eastern most locality of the species. 
HABITAT AND LIFE HISTORY TRAITS. — Phaneroptera gracilis has only been found in a man made opened area, with only tall grasses (entirely lacking ligneous plants).

\section{DESCRIPTION COMPLEMENT}

Stridulatory file: With 88 lamellar teeth; with usual " $\mathrm{S}$ " shape in the genus: 44 wide and widely spaced proximal teeth, 44 small and shortly spaced distal teeth (Fig. 11A).

\section{Calling song (Fig. 15B, C)}

One male has been recorded and IR filmed in the field (SH-048, MNHN-ENSIF2200). At $28^{\circ} \mathrm{C}$, the call of this species consists of irregular widely spaced (90 s) echemes. Individual echemes last 0.9-1.6 s and consists of 12-17 syllables. The calling frequency first harmonic peaks in the ultrasound range (c. $22 \mathrm{kHz}$; many Lebinthus sp. and Conocephalus sp. songs are covering the recording, preventing a more precise analysis).

Genus Platycaedicia Hebard, 1922

Platycaedicia Hebard, 1922: 167.

Type SPECIES. - Platycaedicia obiensis, Hebard, 1922.

\section{REMARKS}

Hebard (1922) included two species in this genus: P. obiensis Hebard, 1922 and P. major (Brunner von Wattenwyl, 1878), the latter often omitted in the litterature. The other species of the genus are $P$. dicranocera Karny, 1926, P. hospes (Brunner von Wattenwyl, 1878) and P. inexpectata (Willemse, 1961).

\section{Platycaedicia sp.}

(Fig. 12)

Material EXAmined. - Vanuatu. (5 $\%$ ), Sanma Province, Espiritu Santo Isl., Luganville, Collège maritime, en ville, attiré par la lumière, Exped. Santo 2006, 28.X.2006, coll. S. Hugel, 1 ○ (SH-049) (MNHN-ENSIF2201). Luganville, site du CTRAV, habitations, $15^{\circ} 27^{\prime} 00^{\prime \prime}$, $167^{\circ} 12^{\prime 2} 26^{\prime} \mathrm{E}, 10 \mathrm{~m}$ alt., nuit, Exped. Santo 2006, 31.X.2006, coll. S. Hugel, 1 ㅇ (SH-050) (MNHN-ENSIF2202).

Penaoru, camp de base, Exped. Santo 2006, X-XII.2006, 3 우 (SH-051, SH-052, SH-053) (MNHN-ENSIF2203, 2204, 2205).

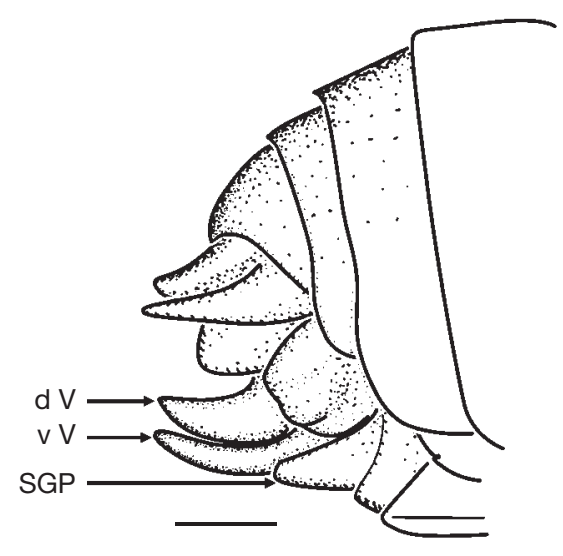

FIG. 12. - Platycaedicia sp., right side view of female terminalia. Abbreviations: see text. Scale bar: $1 \mathrm{~mm}$.

Habitat AND LIFE HISTORY TRAITS. - We observed this species in anthropized areas where it is attracted by habitation lights.

\section{REMARKS}

Five Platycaedicia sp. female specimens have been collected during SANTO 2006 biological survey. The following characters attest their generic identity (Hebard 1922): open tympana on both TI sides, TI flat dorsad, pronotum disk widening caudad, pronotum lateral lobes width less than pronotum lateral lobes depth, FW broader than pronotum length.

Santo specimens are distinctly smaller than $P$. hospes, P. major and P. obiensis; ovipositor valves are thin and regularly narrowing (Fig. 12), unlike P. obiensis. Although not fitting with the species currently considered as belonging to Paracaedicia, Santo specimens are possibly belonging to a species already described under Caedicia Stål, 1874. Indeed, among the 37 species currently considered as Caedicia, some if not many are likely to belong to Paracaedicia as defined by Hebard (1922). A revision and perhaps a redefinition of both Caedicia and Paracaedicia, as well as male descriptions would be required to identify Santo specimens.

\section{Genus Furnia Stål, 1876}

Furnia Stål, 1876: 57.

TyPe SPECIES. — Furnia malaya Stål, 1876. 
Tentative KeY TO FURNIA STÅL, 1876 SPECIES

Furnia malaya Stål, 1876 male, F. acuminata (Brunner von Wattenwyl, 1891) and F. exotica (Brunner von Wattenwyl, 1878) females are unknown.

1. Fastigium pointing; male SGP posterior margin strait ................................. F. exotica

— Fastigium not pointing; when known, male SGP distinctly emarginated ..................... 2

2. Pronotum lateral lobe distinctly longer than high; FW length $<23 \mathrm{~mm}$; male SGP with a V-shaped emargination, epiproct truncated ......................................... F. acuminata

- Pronotum lateral lobe as long as high as or higher than long; FW length $>21 \mathrm{~mm}$ and male SGP with a U-shaped emargination, or FW length $>30 \mathrm{~mm}$ and male SGP with a $\mathrm{V}$-shaped emargination; female FW length $>26 \mathrm{~mm}$ 3

3. FW long (> $36 \mathrm{~mm}$ ); male SGP emargination not U-shaped (Fig. 14F); ovipositor long, $>10 \mathrm{~mm}$, moderately upcurved; pronotum lateral lobe higher than long ........ F. bakeri

- FW shorter (<36 mm); when known, male SGP with U-shaped emargination (Figs 13I; $14 \mathrm{~B}$ ); ovipositor short, $<9 \mathrm{~mm}$, strongly upcurved, enlarged on the middle (Figs 13B; $14 \mathrm{E})$; pronotum lateral lobe about as high as long as or higher than long ................... 4

4. Pronotum lateral lobe higher than long; fastigium frontis dorsal margin strait (Fig. 14D) F. malaya

- Pronotum lateral lobe about as high as long; fastigium frontis dorsal margin rounded (Figs 13A; 14A) 5

5. Fastigium frontis dorsal margin narrowly rounded (Fig. 14A); male SGP emargination deep (Fig. 14B); male cerci simple, pointing (Fig. 14C); ovipositor length $>8 \mathrm{~mm}$ F. incerta

- Fastigium frontis dorsal margin widely rounded (Fig. 13A); male SGP emargination less deep (Fig. 13I); male cerci apex bent inwards, with a minute spine on the apical dorsal margin (Fig. 13F); ovipositor length $<8 \mathrm{~mm}$ F. insularis

\section{Furnia insularis (Stål, 1876)} (Figs 13; 15D)

\section{Anaulacomera insularis Stål, 1876: 57.}

Furnia insularis - Kirby 1906: 468.

TYPE MATERIAL. — Samoa. c. m. Nr. 6211. 9 holotype (NHRS). High quality pictures examined.

Type locality. - South western Pacific, Samoa.

MATERIAL EXAMINED. - Vanuatu. (6 ơ $0^{7}, 10 \%$ $\%$, Sanma Province, Espiritu Santo Isl., Butmas, forêt sur plateau de Tankara, 1521'56”'S, 166 59'E, $600 \mathrm{~m}$ alt., sur plante, $3 \mathrm{~m}$ de haut, nuit, Exped. Santo 2006, 16.X.2006, coll. S. Hugel, 2 우 (SH-057, SH-059) (MNHN-ENSIF2209, 2211).

Peavot, $14^{\circ} 59^{\prime} 27^{\prime \prime}$ S, $166^{\circ} 47^{\prime} 37^{\prime \prime E}$, 0-5 m alt., végétation arbustive en arrière de plage, nuit, Exped. Santo 2006, 24.X.2006, coll. S. Hugel, 1 ơ (SH-054) (MNHNENSIF2206). - Peavot, 1459'37”S, 16647’04”E,
$38 \mathrm{~m}$ alt., forêt secondaire, ancien jardin, rive $S$ de la rivière principale, terrasse 2 , sur plante $2 \mathrm{~m}$ de haut, nuit, Exped. Santo 2006, 20.X.2006, coll. S. Hugel, 1 ㅇ (SH-061)(MNHN-ENSIF2213). - Same locality and date, forêt secondaire, ancien jardin, nuit, coll. S. Hugel, $10^{\prime \prime}$ (SH-055) (MNHN-ENSIF2207). - Same locality, forêt secondaire, ancien jardin, nuit, 21.X.2006, coll. S. Hugel, 1 \& (SH-056) (MNHN-ENSIF2208). - Same locality, forêt secondaire, ancien jardin, rive $S$ de la rivière principale, terrasse haute, nuit, 23.X.2006, coll. S. Hugel, 2 우 (SH-058, SH-060) (MNHN-ENSIF2210, 2212).

Penaoru, 1900 m, X-XI.2006, coll. E. Boitier, 1 ㅇ (SH069) (MNHN-ENSIF2221). - Penaoru, camp de base, "ortho3", Exped. Santo 2006, X-XI.2006, 3 ơ $^{7}$ (SH-062, SH-063, SH-064) (MNHN-ENSIF2214-2216). - Same locality and date, 3 우 (SH-065, SH-066, SH-067) (MNHN-ENSIF2217, 2218, 2219). - Same locality, 17.XI.2006, $10^{7}$ (SH-068) (MNHN-ENSIF2220).

Peavot, 1459'37'S, 16647'04"E, 38 m alt., forêt secondaire, ancien jardin, rive $S$ de la rivière principale, 

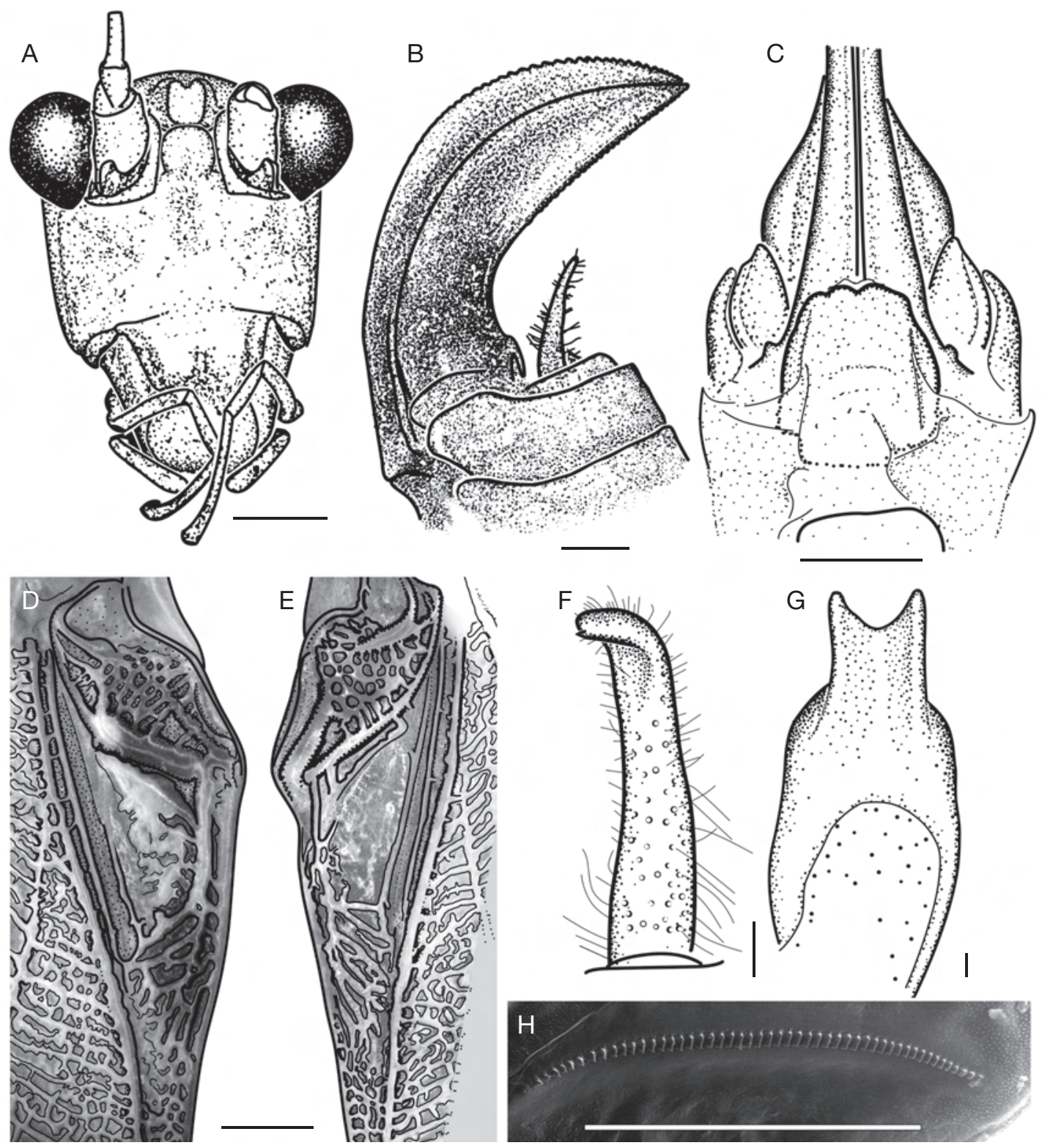

FIG. 13. - Furnia insularis (Stål, 1876): A, female holotype face in frontal view (after unpublished pictures, NHRS); B, female holotype ovipositor in right side view (after unpublished pictures, NHRS); C, female terminalia ventral view (no type specimen from Espiritu Santo, the female holotype subgenital plate is damaged); D, male left forewing anal field in dorsal view (specimen from Espiritu Santo); E, male right forewing anal field in dorsal view (specimen from Espiritu Santo); F, male cercus in dorsal view (specimen from Espiritu Santo); G, male subgenital plate (non type specimen from Samoa as the female holotype [MNHN, L. Chopard Det.]); $\mathbf{H}$, SEM picture of the file. Scale bars: $1 \mathrm{~mm}$.

terrasse haute, sur plante $2 \mathrm{~m}$ de haut, nuit, enregistré, Exped. Santo 2006, 20.X.2006, coll. S. Hugel, $10^{7}$ (SH-159) (MNHN-ENSIF2311).
Diagnosis. - Size medium for the genus, FW length 21.5-29.2 mm (> $35 \mathrm{~mm}$ in F. bakeri Karny, 1921); fastigium frontis dorsal margin broadly rounded (Fig. 13A; 


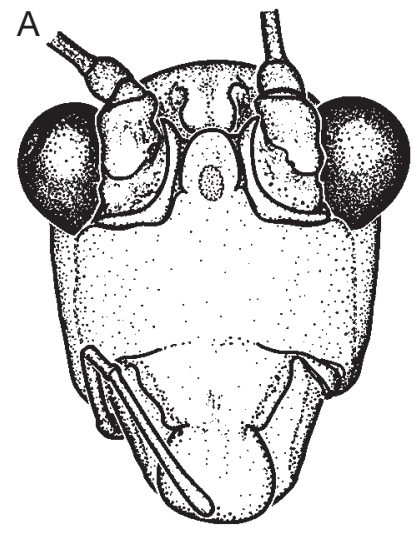

B

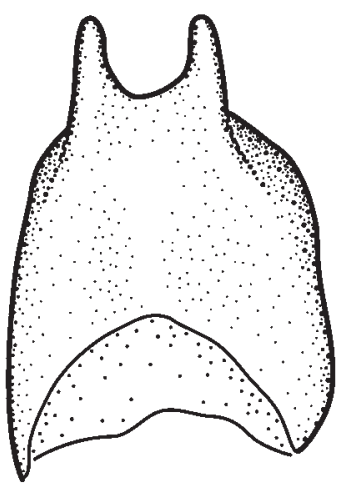

C

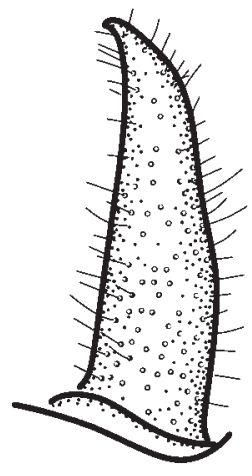

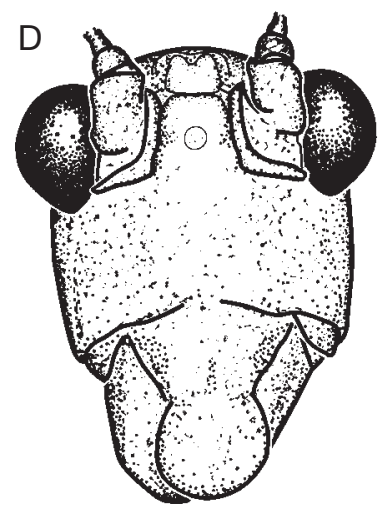
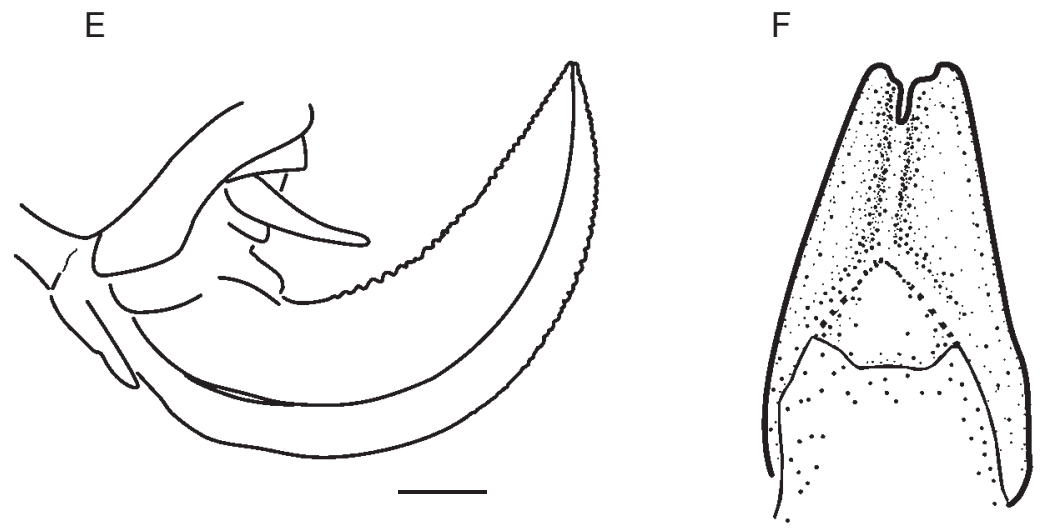

FIG. 14. - Furnia Stål, 1876: A-C, F. incerta (Brunner von Wattenwyl, 1878) (after unpublished pictures from the holotype, NHW); D, E, F. malaya Stål, 1876 (after unpublished pictures of the holotype NHRS); F, F. bakeri Karny, 1921; A, D, frontal view of the face; $\mathbf{B}, \mathbf{F}$, ventral view of male subgenital plate; $\mathbf{C}$, dorsal view of male cercus; $\mathbf{E}$, female ovipositor. Scale bar: $1 \mathrm{~mm}$.

strait in F. malaya, Fig. 14D; narrowly rounded in F. incerta Brunner von Wattenwyl, 1878, Fig. 14A); fastigium not pointing (unlike $F$ exotica); pronotum lateral lobe about as wide as high (wider than high in F. acuminata; higher than wide in F. malaya and F. bakeri); male cerci apex bent inwards, with a minute spine on the apical dorsal margin (Fig. 13F); male SGP with a U-shaped emargination (Fig. 13I; deeper U-shaped emargination in F. incerta, Fig. 14B; no emargination in F. exotica; angular emargination in F. bakeri, Fig. 14F; $\mathrm{V}$-shaped emargination in $F$. acuminata); ovipositor short, $<9 \mathrm{~mm}$, strongly upcurved, enlarged at mid length (Fig. 13B; $>10 \mathrm{~mm}$ and moderately upcurved in $F$. bakeri).

Distribution. - South western Pacific: Samoa (holotype); Fiji, Suva; Vanuatu, Espiritu Santo.
Habitat AND LIFE History TRAITs. - All $F$. insularis specimens have been mostly found in non coastal forests, in both preserved or slightly anthropized areas. This species seems to be strictly active during night hours. Adult are staying on tree or bush foliage, even in undergrowth.

Measurements. - See Table 5.

\section{REDESCRIPTION (after material from Espiritu} Santo)

Head (Fig. 13A). As wide or slightly wider than pronotum; face, genae and occiput smooth, not shiny; occiput relatively flattened; eyes rounded, moderately projecting; in dorsal view: fastigium flat, slightly exceeding the scrobus, not exceeding the 
TABLE 5. - Measurements of Furnia insularis (Stål, 1876). Abbreviations: see text. Note: 1, depends on the preservation.

\begin{tabular}{|c|c|c|c|c|c|c|c|c|c|c|c|c|c|c|c|c|c|c|c|c|c|c|}
\hline & \multirow{2}{*}{$\begin{array}{c}\text { Bd } \\
\text { L }\end{array}$} & \multirow{2}{*}{$\begin{array}{c}\text { Hd } \\
W \\
\text { max. }\end{array}$} & \multirow{2}{*}{$\begin{array}{l}\text { Vtx } \\
\text { W }\end{array}$} & \multicolumn{3}{|c|}{ Prn } & \multicolumn{2}{|c|}{ FW } & \multirow{2}{*}{$\begin{array}{c}\text { A1 } \\
\text { L }\end{array}$} & \multirow{2}{*}{$\begin{array}{l}\mathrm{TI} \\
\mathrm{L}\end{array}$} & \multirow{2}{*}{$\begin{array}{l}\text { TII } \\
\text { L }\end{array}$} & \multirow{2}{*}{$\begin{array}{c}\text { TIII } \\
\mathbf{L}\end{array}$} & \multirow{2}{*}{$\begin{array}{l}\text { FI } \\
\text { L }\end{array}$} & \multirow{2}{*}{$\begin{array}{c}\text { FII } \\
\text { L }\end{array}$} & \multicolumn{2}{|c|}{ FIII } & \multicolumn{3}{|c|}{ SGP } & \multirow{2}{*}{$\begin{array}{c}\text { Cer } \\
\text { L }\end{array}$} & \multicolumn{2}{|c|}{ Ovs } \\
\hline & & & & $\mathbf{L}$ & $\begin{array}{c}\text { W } \\
\text { max.r }\end{array}$ & $\underset{\max .}{\mathbf{H}}$ & $\mathbf{L}$ & $\begin{array}{c}\text { W } \\
\text { mid. }\end{array}$ & & & & & & & $\mathbf{L}$ & $\begin{array}{c}\text { W } \\
\text { max.I }\end{array}$ & max & $\begin{array}{c}\text { W1 } \\
\text { base }\end{array}$ & $\begin{array}{c}\text { W } \\
\text { apex }\end{array}$ & & $\mathbf{L}$ & $\begin{array}{c}\text { W } \\
\text { max }\end{array}$ \\
\hline $\begin{array}{l}\text { \& holotyp } \\
\text { Samoa }\end{array}$ & e 1 & & & 5.0 & & & 28.0 & 7.0 & & & & & & & 17.0 & & & & & & 7.8 & \\
\hline $\begin{array}{l}0^{7} \mathrm{n}=6 \\
\text { Santo }\end{array}$ & 15.3 & 2.5 & 0.3 & 4.0 & 2.7 & 2.82 & 23.3 & 4.8 & 1.2 & 5.6 & 7.21 & 17.7 & 4.1 & 6.31 & 14.8 & 2.2 & 1.9 & 1.7 & 4.1 & 6.3 & - & - \\
\hline $\begin{array}{l}\min . \\
\max .\end{array}$ & $\begin{array}{l}11.4 \\
17.4\end{array}$ & $\begin{array}{l}2.2 \\
2.8\end{array}$ & $\begin{array}{l}0.3 \\
0.3\end{array}$ & $\begin{array}{l}3.5 \\
4.4\end{array}$ & $\begin{array}{l}2.6 \\
2.9\end{array}$ & $\begin{array}{l}2.72 \\
3.12\end{array}$ & $\begin{array}{l}21.5 \\
24.5\end{array}$ & $\begin{array}{l}4.5 \\
5.5\end{array}$ & $\begin{array}{l}1.1 \\
1.3\end{array}$ & $\begin{array}{l}5.3 \\
5.9\end{array}$ & $\begin{array}{l}6.81 \\
7.81\end{array}$ & $\begin{array}{l}16.9 \\
18.9\end{array}$ & $\begin{array}{l}4.0 \\
4.4\end{array}$ & $\begin{array}{l}5.91 \\
6.61\end{array}$ & $\begin{array}{l}14.0 \\
15.8\end{array}$ & $\begin{array}{l}2.1 \\
2.3\end{array}$ & $\begin{array}{l}1.6 \\
2.0\end{array}$ & $\begin{array}{l}1.3 \\
1.9\end{array}$ & $\begin{array}{l}4.0 \\
4.4\end{array}$ & $\begin{array}{l}5.9 \\
6.6\end{array}$ & - & $\begin{array}{l}- \\
-\end{array}$ \\
\hline 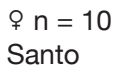 & 18.1 & 3.0 & 0.3 & 4.4 & 2.8 & 3.02 & 27.8 & 5.9 & - & 6.4 & 8.51 & 19.4 & 4.7 & 7.31 & 16.3 & 2.4 & 1.3 & 1.3 & - & - & 7.0 & 1.9 \\
\hline $\begin{array}{l}\min . \\
\text { max. }\end{array}$ & $\begin{array}{l}14.7 \\
21.2\end{array}$ & $\begin{array}{l}2.7 \\
3.2\end{array}$ & $\begin{array}{l}0.3 \\
0.3\end{array}$ & $\begin{array}{l}4.1 \\
4.7\end{array}$ & $\begin{array}{l}2.7 \\
3.0\end{array}$ & $\begin{array}{l}2.82 \\
3.32\end{array}$ & $\begin{array}{l}26.4 \\
29.2\end{array}$ & $\begin{array}{r}5.6 \\
6.1\end{array}$ & $\begin{array}{l}- \\
-\end{array}$ & $\begin{array}{l}5.7 \\
7.0\end{array}$ & $\begin{array}{l}7.91 \\
9.02\end{array}$ & $\begin{array}{l}17.4 \\
21.2\end{array}$ & $\begin{array}{l}4.3 \\
5.0\end{array}$ & $\begin{array}{l}6.71 \\
7.91\end{array}$ & $\begin{array}{l}14.5 \\
18.0\end{array}$ & $\begin{array}{l}2.2 \\
2.7\end{array}$ & $\begin{array}{l}1.1 \\
1.4\end{array}$ & $\begin{array}{l}1.3 \\
1.4\end{array}$ & - & - & $\begin{array}{l}6.6 \\
7.5\end{array}$ & $\begin{array}{l}1.8 \\
2.1\end{array}$ \\
\hline
\end{tabular}

fastigium frontis, truncated, 0.11 (min: 0.08; max: 0.13 ) times wider in the apex than head maximal width (eyes not included), cuneiform, with a median longitudinal sulcus; in frontal view, fastigium frontis higher than wide, notched dorsally by dorsal sulcus, distinctly separated from the frons by a deep sulcus, lateral ocelli distinct in some specimens on the lateral sides of the fastigium verticis; in frontal view: fastigium frontis higher than wide, inter scrobus width 0.21 (min: 0.19; max: 0.25) times as wide as head maximal width (eyes not included), superior border widely arched; median ocellus not distinct in the $P$ holotype (Samoa) but well distinct in some specimens from Espiritu Santo, oval, less wide as half fastigium width; frons/genae limit without carina but with a distinct depression; scapus less wide than eyes (frontal view), about as wide as the fastigium frontis, without spine.

Thorax. Pronotum: smooth, not shiny; 1.5 (min: 1.4; max: 1.7) times longer than wide (maximal width including lateral lobes lateral expansion) discus anterior margin weakly convex, posterior margin rounded (convex) with a narrow inconspicuous concavity on the middle; prozona and mesozona weakly arched, metazona flattened; discus posterior sulcus inconspicuous, other transversal sulci absent; with an inconspicuous longitudinal sulcus on the metazona; without median and lateral carinae; lateral lobe as wide as high (average 1.0; min: 0.9; max:1.1); rounded, anterior margin weakly concaves. Prosternum inermis as usual; mesosternum with rounded posterior lobes; metasternum with 2 diverging anterior spines well distinct from the lateral lobes rounded posteriorly. FW 4.8 (min: 4.5; max: 5.1) times as long as wide (on the middle); with transparent cells, with moderately dense reticulation; with sub parallel sides; apex rounded; HW distinctly exceeding the FW.

Legs. TI with uncovered oval inner and outer tympana; distinctly inflated on tympanal area; without clear carinae; flattened ventrally; with 1 inner ventral apical spur and 1 outer ventral apical spur; with 2-5 inner preapical spurs (usually 5); with 1-5 (usually 4 or 5) outer preapical spurs, without dorsal spurs or spines. FI with one apical and one minute ventral spine on each knees lobe; without clear carinae; with 5-10 (usually 6 or 7) inner ventral spines; without spines on the ventral outer margin. TII laterally flattened near the knee; without clear carinae; with 1 ventral apical spurs on each side; with 6-9 (usually 8) ventral anterior preapical spurs; with 4-7 ventral posterior spurs (usually 7); without dorsal spurs. FII with one apical and one minute ventral spine on each knee lobe; without distinct carinae; rounded dorsally; with 8-13 ventral anterior spines; without ventral posterior spines. TIII with 2 ventral and 1 dorsal apical spurs on each side; laterally flattened; with 10-13 inner ventral spurs; $14-19$ outer ventral spurs; 27-33 inner dorsal spines; 25-34 outer dorsal spines. FIII relatively thick, 6.7 (min: 6.3; max: 7.2) times longer than FIII maximal width; 
with one apical and one ventral spine on each knee lobe; with 2 ventral carinae, the external more elevated; with 2-6 spines on the inner ventral carina, near the knee; with $8-14$ spines on the outer ventral carina.

\section{Colour}

The general coloration is pale green (yellowish in dead specimens). When visible, the ocelli are creamish. FW veins and veinlets pale green, cells hyaline, stridulum veins brown and cream, anal field veinlets yellowish; HW hyaline except the visible apex of anterior field; ventral and internal area of femora from yellow to orange. Ovipositor green with darkened apex.

\section{SEXUAL DIMORPHISM}

Males are significantly smaller than females. Female size slightly longer than male size (FIII $14.8 \pm$ $0.3 \mathrm{~mm}$ vs. $16.3 \pm 0.5 \mathrm{~mm}$ ); female FW about $20 \%$ longer than male FW.

\section{Male}

Singing apparatus (Fig. 13D, E): left and right FW anal field with thickened opaque cells; the file vein (A1) is well distinct (dorsal view) on the left FW; file with $46.8 \pm 1.04$ (min: 43; max: 50) lamellar teeth (Fig. 13H). Right FW tympanum not membranous, poorly defined, about 2.6 times as long as wide. Terminalia: tergite $\mathrm{X}$ (last) posterior margin concave dorsally; epiproct hidden by the tergite X; cerci apex flattened, bent inwards or upwards with a right angle (depending on the cerci position); with a minute spine on the apical dorsal margin (Fig. 13F). SGP without styli; elongated, at least as long as wide, usually longer (depending on the specimen preservation); with lateral carinae on the distal lateral margins, converging moderately; apex with a wide rounded emargination 0.14 (min: 0.13 ; max: 0.16) times as deep as the SGP maximal length; the emargination separates the SGP in two apical lobes with rounded apex, with a weak median longitudinal carina (Fig. 13G).

\section{Female}

SGP (Fig. 13C) weakly sclerotized, as wide as long; rounded on the apex; with a minute rounded apical emargination (destructed on the 9 holotype). Ovipositor (Fig. 13B) strait on the base and falciform after the base; with denticulations in second half of the ventral and dorsal margins; apex pointing. Ovipositor 3.7 (min: 3.5; max: 3.8) times as long (apex to base of the ventral margin) as ovipositor maximal width (at the beginning of the denticulations).

Calling SONG (Fig. 15D)

Males call during night hours seemingly above $2 \mathrm{~m}$. One male has been recorded and IR filmed in the field (SH-055, MNHN-ENSIF2207). At $26^{\circ} \mathrm{C}$, the call of this species consists of irregular widely spaced (every $47.1 \pm 19.0 \mathrm{~s}$; min: 21.1 ; max: 103.6) syllables, either isolated or organized in short echemes (average $2.0 \pm 0.3$, range 1-3). Within a series, syllables are separated by $80.6 \pm 24.7 \mathrm{~ms}$ (min: 30.5; max: 125.8). The calling frequency first harmonic peaks between $13-15 \mathrm{kHz}$, with distinct second harmonics at $26-30 \mathrm{kHz}$ (many Cardiodactylus sp. [Eneopterinae crickets] songs are covering the recording, preventing a more precise analysis).

\section{REMARKS}

The sixteen Furnia specimens collected in Espiritu Santo are similar to F. insularis female holotype from Samoa (although slightly smaller in average). Furnia insularis occurs also in Fiji (Bruner 1916), from which the first male ever reported of this species actually originates (Caudell 1927). The Furnia males collected in Santo are not different from Caudell's description, except the cerci. Caudell illustrated and described the cerci of his Fijian male as having a folded apex, whereas well preserved specimens of Santo have the apex of cerci bent with a right angle. In shrunken specimens from Santo (dried from alcohol), cerci are also appearing as folded, suggesting that Caudell's specimen was also shrunken by a drying of alcohol preserved specimens. This was confirmed by David Nickle who examined the specimens (in litt.).

\section{Genus Conocephalus Thunberg, 1815}

Conocephalus Thunberg, 1815: 214, 271. 


\section{A}
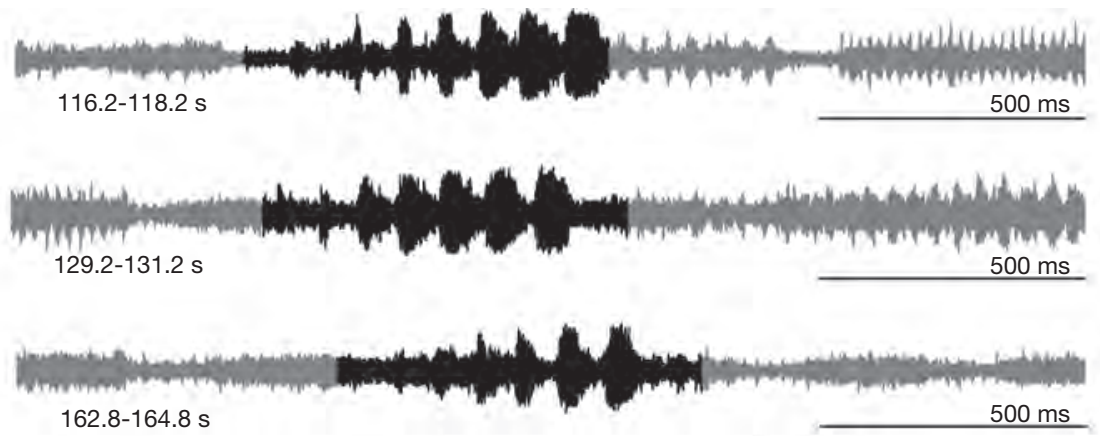

B
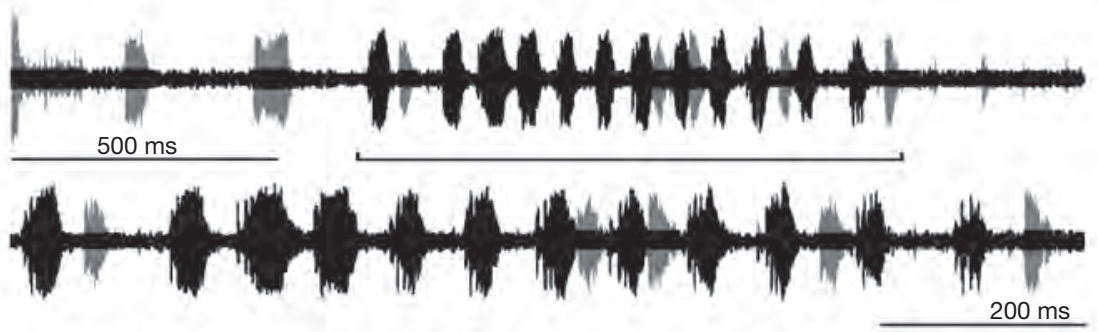

c H+H

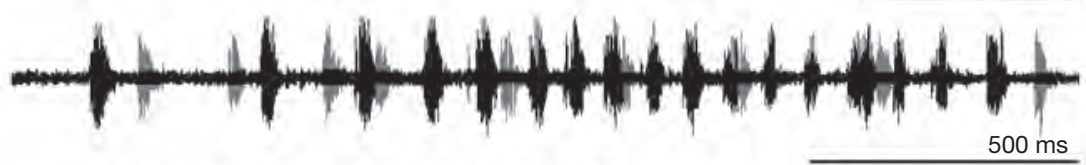

D
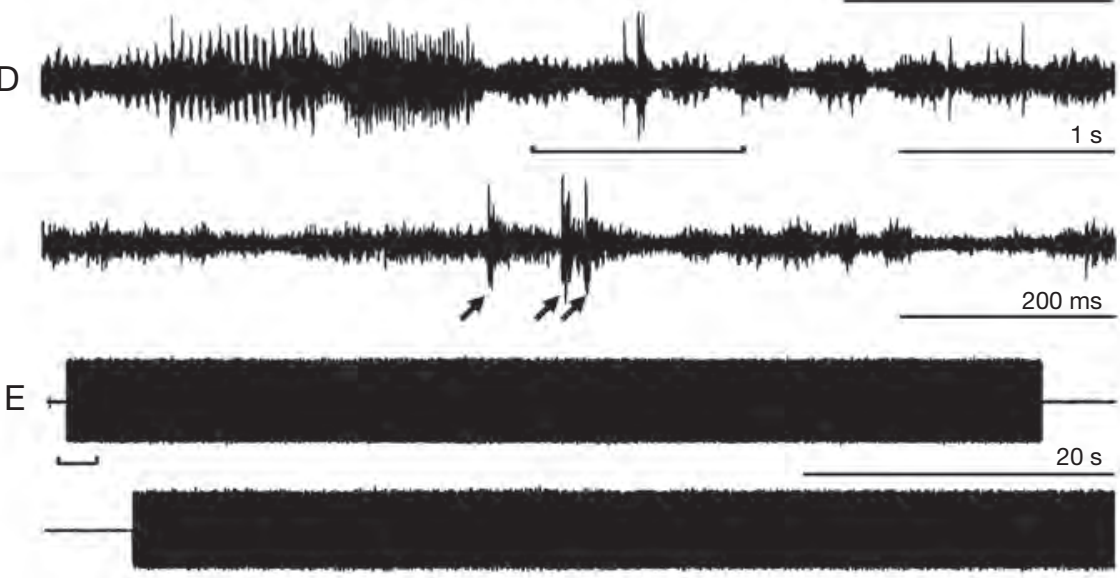

$1 \mathrm{~s}$

FIG. 15. - Calling songs: A, Ityocephala francoisi Bolívar, 1903 specimen MNHN-ENSIF2188, 20H30, $21^{\circ} \mathrm{C}, 2 \mathrm{~m}$ high, Cardiodactylus sp. (Eneopterinae cricket) and Salomona redtenbacheri Brongniart, 1897 are singing around (grey); B, C, Phaneroptera gracilis (Burmeister, 1838), the specimen MNHN-ENSIF2200 has been IR filmed in order to distinguish its call (black) from the other calls (Conocephalus sp. and crickets, in grey) $\mathrm{OH} 30,20^{\circ} \mathrm{C}$; D, Furnia insularis (Stål, 1876), the specimen MNHN-ENSIF2311 has been IR filmed in order to distinguish its calls (arrows) from the background calls (Cardiodactylus sp. and Salomona redtenbacheri, see Fig. 20) $20 \mathrm{H} 00,21^{\circ} \mathrm{C}, 3 \mathrm{~m}$ from the specimen; E, Pseudorhynchus lessonii Serville, 1838, specimen MNHN-ENSIF2282, $19 \mathrm{H} 40,22^{\circ} \mathrm{C}$. All songs recorded in situ. 

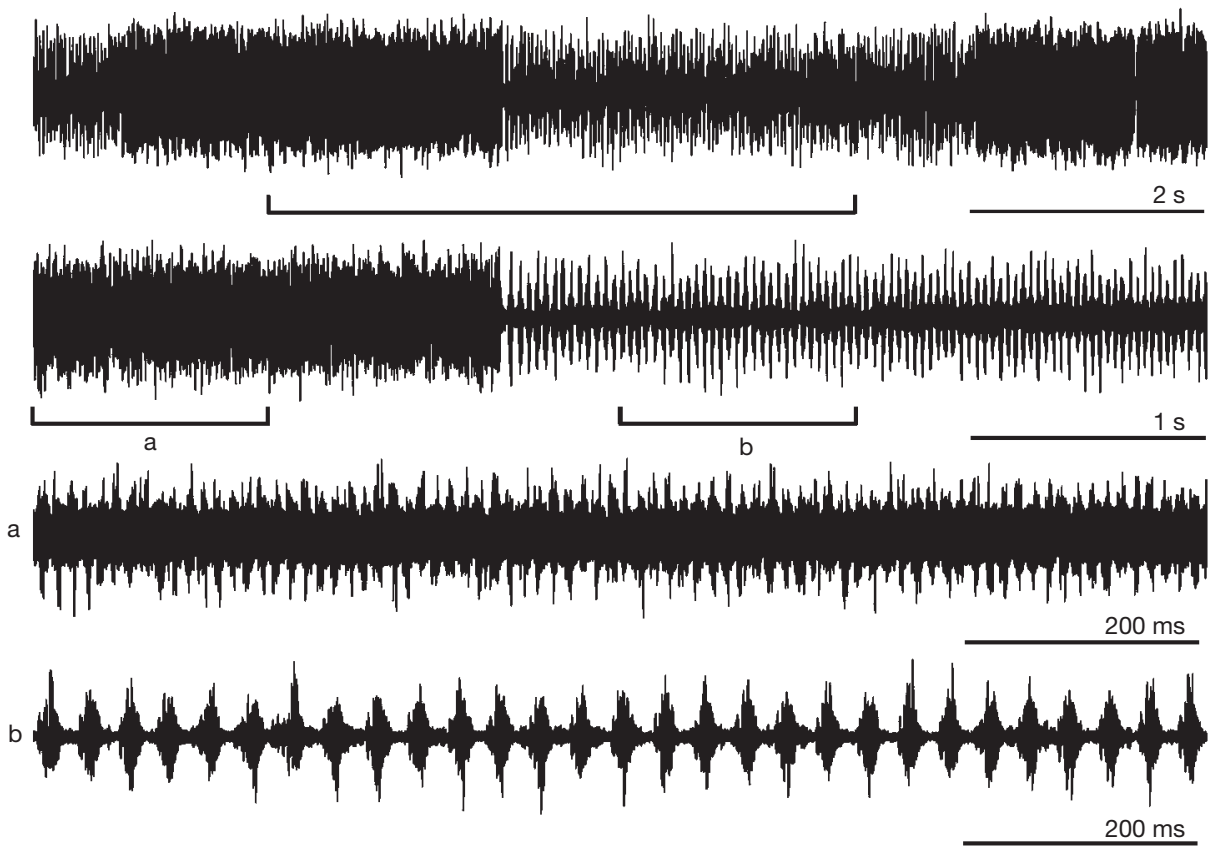

FIG. 16. - Calling song of Conocephalus upoluensis (Karny, 1907), specimen MNHN-ENSIF2269, $20 \mathrm{H} 30,21.5^{\circ} \mathrm{C}$

Conocephalus upoluensis (Karny, 1907)

(Figs 11B, H; 16)

Xiphidium (Xiphidion) modestum upoluense Karny, 1907: 95.

Conocephalus upoluensis - Pitkin 1980: 341.

Conocephalus brevixiphus Willemse, 1942: 95.

TyPe MATERIAL. - Conocephalus upolensis: Samoa. Upolu, $\sigma^{7}$ lectotype (NHW). Not examined.

Conocephalus brevixiphus: Australia. Northern Territory, Burnside, 9 holotype (NHMB). Not examined.

TyPe LOCAlity. — Southwestern Pacific, Samoa, Upolu.

MATERIAl EXAMined. - Vanuatu. (8 $0^{7} 0^{7}, 2$ 우), Sanma Province, Espiritu Santo Isl., Matantas, pointe

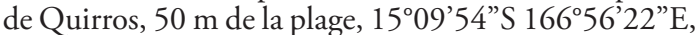
végétation basse et arbustive en zone supralittorale, nuit, Exped. Santo 2006, 18.X.2006, coll. T. Robillard, 1 O" (SH-108 TR-178) (MNHN-ENSIF2260).

Luganville, site du CTRAV, $15^{\circ} 27^{\prime} 00^{\prime \prime}$ S, 167²'26”E, $2 \mathrm{~m}$ alt., pelouse, zone herbacée, nuit, enregistrement TR take 2, Exped. Santo 2006, 12.X.2006, coll. T. Robillard, $10^{7}$ (SH-109 TR-002) (MNHN-ENSIF2261). Same locality and date, nuit, coll. S. Hugel, $10^{7}$
(SH-110) (MNHN-ENSIF2262). - Same locality and date, nuit, enregistrement spn2, coll. S. Hugel, $10^{7}$ (SH-111) (MNHN-ENSIF2263). - Same locality and date, coll. S. Hugel, 3 O $^{\circ}$ (SH-112-114) (MNHN-ENSIF2264-2266); 1 \% (SH-116) (MNHNENSIF2268); 1 o", enregistrement spn1 (SH-117) (MNHN-ENSIF2269).

Chemin côtier entre Peavot et Pealulup, zone herbacée, Exped. Santo 2006, 24.X.2006, coll. S. Hugel, 1 † (SH-115) (MNHN-ENSIF2267).

Distribution. - Widely distributed in the South western Pacific Islands. Already known from Espiritu Santo (Pitkin 1980).

Habitat AND LifE HISTORY TRAITS. - We found this species in open anthropized areas (pasturelands, road sides) of low altitude.

\section{DESCRIPTION COMPLEMENT}

Stridulatory file with 30 lamellar teeth unevenly spaced along the length of the file, being closer together at the distal end, proximal teeth knobshaped, median triangular and distal minute and lamellar; with numerous minute spinules on the anterior side at middle (Fig. 11B). 
CALling SONG (Fig. 16)

Males call during both night and day. We recorded three specimens in early night hours. The echemesequence of $C$. upoluensis call has two repeating distinct parts: a series of individual short syllables, alternated with a train of continuous buzz (this seems not to be always the case, see Rentz 1996: CD). The echeme-sequence has an average duration of $62 \pm 16 \mathrm{~s}$. The duration of the individual syllables series is $5.90 \pm 2.34 \mathrm{~s}$ (min: 3.76; max: 11.13), and the rate of syllables is $30.5 / \mathrm{s}$. The duration of the buzz train is shorter: $2.75 \pm 0.66 \mathrm{~s}$ (min: 1.56; max: 3.67 ), and the rate is $80.9 / \mathrm{s}$. The calling frequency first harmonic peaks between $20-22 \mathrm{kHz}$ ).

\section{Conocephalus semivittatus (Walker, 1869)}

Decticus semivittatus Walker, 1869: 263.

Conocephalus semivittatus - Pitkin 1980: 335.

REMARK

All the specimens of this species collected in Espiritu Santo belong to Conocephalus semivittatus vittatus.

\section{Conocephalus semivittatus vittatus}

(Redtenbacher, 1891)

(Figs 11C, G; 17)

Xiphidium vittatum Redtenbacher, 1891: 513.

Xiphidium geniculare Redtenbacher, 1891: 527 (type locality: Indonesia, Maluku, Aru Islands). - Willemse 1925: 515 .

Conocephalus semivittatus vittatus - Pitkin 1980: 338.

TYPE MATERIAL. - Conocephalus semivittatus vittatus: Indonesia. Aru Isl., Ribbe, ơ lectotype (BMNH). Not examined.

Xiphidium geniculare: Indonesia. Aru Isl., Ribbe, $0^{x}$ lectotype (BMNH). Not examined.

TYPE LOCALITY. — Indonesia, Maluku, Aru Islands.

Material eXAmined. - Vanuatu. (20 0 $0^{\pi}, 17$ 우), Sanma Province, Espiritu Santo Isl., Butmas, piste entre camp et plateau Tankara, $600 \mathrm{~m}$ alt., jour, $9 \mathrm{~h} 00 \mathrm{am}$, herbes hautes en bord de piste, $\mathrm{h}=50 \mathrm{~cm}$ en train de chanter, photo TR4, Exped. Santo 2006, 14.X.2006, coll. T. Robillard, 1 o' (TR-069 SH-075) (MNHNENSIF2227). - Butmas, lisière proche du camp, nuit, $600 \mathrm{~m}$ alt., herbes hautes en bord de piste, $c .50 \mathrm{~cm}$, Exped. Santo 2006, 14.X.2006, coll. T. Robillard, 1 O" (SH-076) (MNHN-ENSIF2228). - Butmas, grotte de Fapon, forêt dans doline, 1519'51.6"S, $166^{\circ} 57^{\prime} 53.6^{\prime \prime} \mathrm{E}$, sur plante, jour, Exped. Santo 2006, 15.X.2006, coll. T. Robillard, 1 ơ (TR-115 SH-079) (MNHN-ENSIF2231). - Butmas, camp, $600 \mathrm{~m}$ alt., Exped. Santo 2006, 17.X.2006, coll. T. Robillard, 1 o" (TR-158 SH-080) (MNHN-ENSIF2232). - Butmas, camp, $600 \mathrm{~m}$ alt., pelouse, zone herbacée, Exped. Santo 2006, 16.X.2006, coll. T. Robillard, 1 \% (TR-138 SH-078) (MNHN-ENSIF2230). - Butmas, $600 \mathrm{~m}$ alt., jour, pelouse/zone herbacée, Exped. Santo 2006, 16.X.2006, coll. S. Hugel, 2 O O$^{7}$ (SH-086, SH-088) (MNHN-ENSIF2238, 2240). - Same locality and date, jour, enregistrement spn2, coll. S. Hugel, $1 \mathrm{O}^{\text {( }}$ (SH-074) (MNHN-ENSIF2226). - Butmas, $600 \mathrm{~m}$ alt., pelouse, zone herbacée, Exped. Santo 2006, 16.X.2006, coll. S. Hugel, 1 \& (SH-101) (MNHN-ENSIF2253). - Same locality and date, enregistrement, coll. S. Hugel, $10^{7}$ (SH-106) (MNHN-ENSIF2258). — Butmas, $600 \mathrm{~m}$ alt., herbes hautes en bord de piste, Exped. Santo 2006, 16.X.2006, coll. S. Hugel, 1 ㅇ (SH-096) (MNHNENSIF2248). - Butmas, village, $600 \mathrm{~m}$ alt., pelouse, zone herbacée, de jour, Exped. Santo 2006, 13.X.2006, coll. S. Hugel, 1 ơ (SH-084) (MNHN-ENSIF2236). - Same locality and date, Exped. Santo 2006, coll. S. Hugel, 5 우 (SH-093, SH-097, SH-103-105) (MNHN-ENSIF2245, 2249, 2255, 2256, 2257).

Chemin côtier entre Peavot et Pealulup, zone herbacée, Exped. Santo 2006, 24.X.2006, coll. S. Hugel, 5 O" 0" (SH-083, SH-085, SH-087, SH-090, SH-091), 1 (SH-092) (MNHN-ENSIF2235, 2237, 2239, 2242, 2243, 2244).

Peavot, 1459'37"S, 166 47'04”E, $38 \mathrm{~m}$ alt., clairière dans forêt secondaire sur ancien jardin, enregistrement spn1, Exped. Santo 2006, 20.X.2006, coll. S. Hugel, $10^{\prime \prime}$ (SH-073) (MNHN-ENSIF2225). - Peavot, $14^{\circ} 59^{\prime} 09^{\prime}$ "S, $166^{\circ} 47^{\prime} 39^{\prime \prime} \mathrm{E}$, végétation arbustive en arrière de plage, nuit, Exped. Santo 2006, 24.X.2006, coll. L. Desutter-Grandcolas, $10^{7}$ (SH-081) (MNHNENSIF2233). - Peavot, 1459'09”S, 16647'39”E, pelouse, zone herbacée, enregistrement spn2, Exped. Santo 2006, 20.X.2006, coll. S. Hugel, 1 Ơ (SH-082) (MNHN-ENSIF2234). - Same locality and date, Exped. Santo 2006, coll. S. Hugel, 2 우 (SH-098, SH-099) (MNHN-ENSIF2250, 2251).

Big Bay, Matantas, prox. grotte, forêt secondaire, clairière, Exped. Santo 2006, 27.X.2006, coll. S. Hugel, 1 ㅇ (SH100) (MNHN-ENSIF2252). - Big Bay, Matantas, Vatthé Conservation area, $15^{\circ} 20^{\prime} \mathrm{S}, 166^{\circ} \mathrm{9} 5^{\prime} \mathrm{E}$, enregistrement, Exped. Santo 2006, 27.X.2006, coll. S. Hugel, $10^{7}$ (SH-071) (MNHN-ENSIF2223). 
Village de Kole, Loru protected area, végétation bord de chemin, jour, Exped. Santo 2006, 28.X.2006, coll. L. Desutter-Grandcolas, 1 웅-077) (MNHNENSIF2229).

Natawa, clairière en forêt pâturée, $15^{\circ} 19^{\prime} 29^{\prime \prime}$, $167^{\circ} 12^{\prime} 09^{\prime \prime}$, jour, Exped. Santo 2006, 29.X.2006, coll. L. Desutter-Grandcolas, 1 ㅇ (SH-107) (MNHNENSIF2259). - Same locality and date, enregistrement, coll. S. Hugel, 1 ơ (SH-072) (MNHN-ENSIF2224). Natawa, clairière en forêt paturée, herbes basses, Exped. Santo 2006, 29.X.2006, coll. S. Hugel, jour, 1 (SH-095) (MNHN-ENSIF2247).

Funafus, 15³2'46.4”S, 16700'46”'E, jour, Exped. Santo 2006, 30.X.2006, coll. S. Hugel, 1 Ơ $^{7}$ (SH-089), 2 우 (SH-094, SH-102) (MNHN-ENSIF2241, 2246, 2254).

DisTRIBUTION. - Widely distributed in the Melanesian area. Already known from Espiritu Santo (Willemse 1925 as Xiphidion geniculare).

HABITAT AND LIFE HISTORY TRAITS. - We recorded this species in open anthropized areas (pasturelands, road sides) as well as small clearings of both low and mid-altitude $(0-600 \mathrm{~m})$.

\section{DESCRIPTION COMPLEMENT}

Stridulatory file with 45 teeth unevenly spaced along the length of the file, being closer together at the distal end, proximal and distal teeth small and lamellar, median teeth wider and knob-shaped; with numerous spinules on both sides of the file (Fig. 11C).

\section{CALling SONG (Fig. 17)}

Males call during both night and day. The echemesequence of $C$. semivittatus vittatus call has two repeating distinct parts: a series of individual short syllables, alternated with a train of continuous buzz. The echeme-sequence has an average duration of $6.5 \pm 0.7 \mathrm{~s}$ (min: 2.3; max: 14.1). The duration of the individual syllables series is $0.55 \pm 0.53 \mathrm{~s} \mathrm{(min:}$ 0.11 ; max: 2.25 ) and the rate of syllables is $18.99 \pm$ 4.27/s (min: 14.02; max: 25.10). The duration of the buzz train is $1.18 \pm 0.85 \mathrm{~s}$ (min: 0.10 ; $\max : 2.71$ ) and the rate is $66.14 \pm 15.76 / \mathrm{s}$ (min: 44.80 ; max: 78.81). Studio-recorded specimens grouped (males and females) in the same container have displayed a modified call pattern, with repeated short buzz trains (duration: $139 \pm 26 \mathrm{~ms}$, min: 72, max: 171; rate: $52.69 \pm 10.08 / \mathrm{s}$, min: 42.06, max: 65.39) alternated with short series (duration: $210 \pm 71 \mathrm{~ms}$, min: 131, max: 329) of short syllables (Fig. 17C); this song might correspond to rivalry and/or courtship song. The calling frequency first harmonic peaks between $18.5-22.5 \mathrm{kHz}$ ). Six specimens have been recorded.

\section{Conocephalus oceanicus (Le Guillou, 1841)} (Fig. 11D, F)

Xiphidion oceanicum Le Guillou, 1841: 294.

Conocephalus oceanicus - Karny 1912: 13. — Pitkin 1980: 329.

Xiphidium affine Redtenbacher, 1891: 513 (type locality: South western Pacific, Fiji). — Willemse 1925: 515.

TYPE MATERIAL. - Lectotype selected by Pitkin, L.M., 1979 [printed]; Xiphidion oceanicum Le Guillou det. L. M. Pitkin, 1980 [printed]; ơ (MNHN-ENSIF1632). Paralectotypes: idem, 3 우 (MNHN-ENSIF857, 973, 974). Not examined.

Xiphidium affine: Fiji. ơ lectotype (NHW). Not examined.

TyPe Locality. — [Pacific, Southwestern Pacific, Samoa] Hamoa, arrou., etc. [sic Le Guillou 1841].

Material eXamined. - Vanuatu. (3 $\left.\sigma^{7} o^{7}\right)$, Sanma Province, Espiritu Santo Isl., Luganville, site du CTRAV, $15^{\circ} 27^{\prime} 00^{\prime \prime}$ ' $167^{\circ} 12^{\prime} 26^{\prime \prime E}, 2 \mathrm{~m}$ alt., pelouse, zone herbacée, Exped. Santo 2006, 12.X.2006, coll. S. Hugel, 1 o" (SH-070) (MNHN-ENSIF2222). - Same locality and date, pelouse, zone herbacée, sur plante, nuit, Exped. Santo 2006, coll. T. Robillard, 1 o' (TR-001 SH-118) (MNHN-ENSIF2270).

Big Bay, Matantas, prox. grotte, forêt secondaire, clairière, Exped. Santo 2006, 27.X.2006, coll. S. Hugel, 1 O" (SH-131) (MNHN-ENSIF2283).

Distribution. - Widely distributed in the Pacific. Already known from Espiritu Santo (Willemse 1925 as Xiphidion affine).

HABITAT AND LIFE HISTORY TRAITS. — We recorded this species in one strongly anthropized locality (pasturelands) near the shore, and one clearing on a secondarized forest. Willemse (1925) recorded it from Chuuri 300-600 m and Hog Harbour, open forest.

\section{DESCRIPTION COMPLEMENT}

Stridulatory file (Fig. 11D) with 52-58 teeth: proximal half with wide knob-shaped teeth, distal half with smaller lamellar teeth; with 3-6 spinules on the anterior base (file already illustrated in Pitkin 1980). 

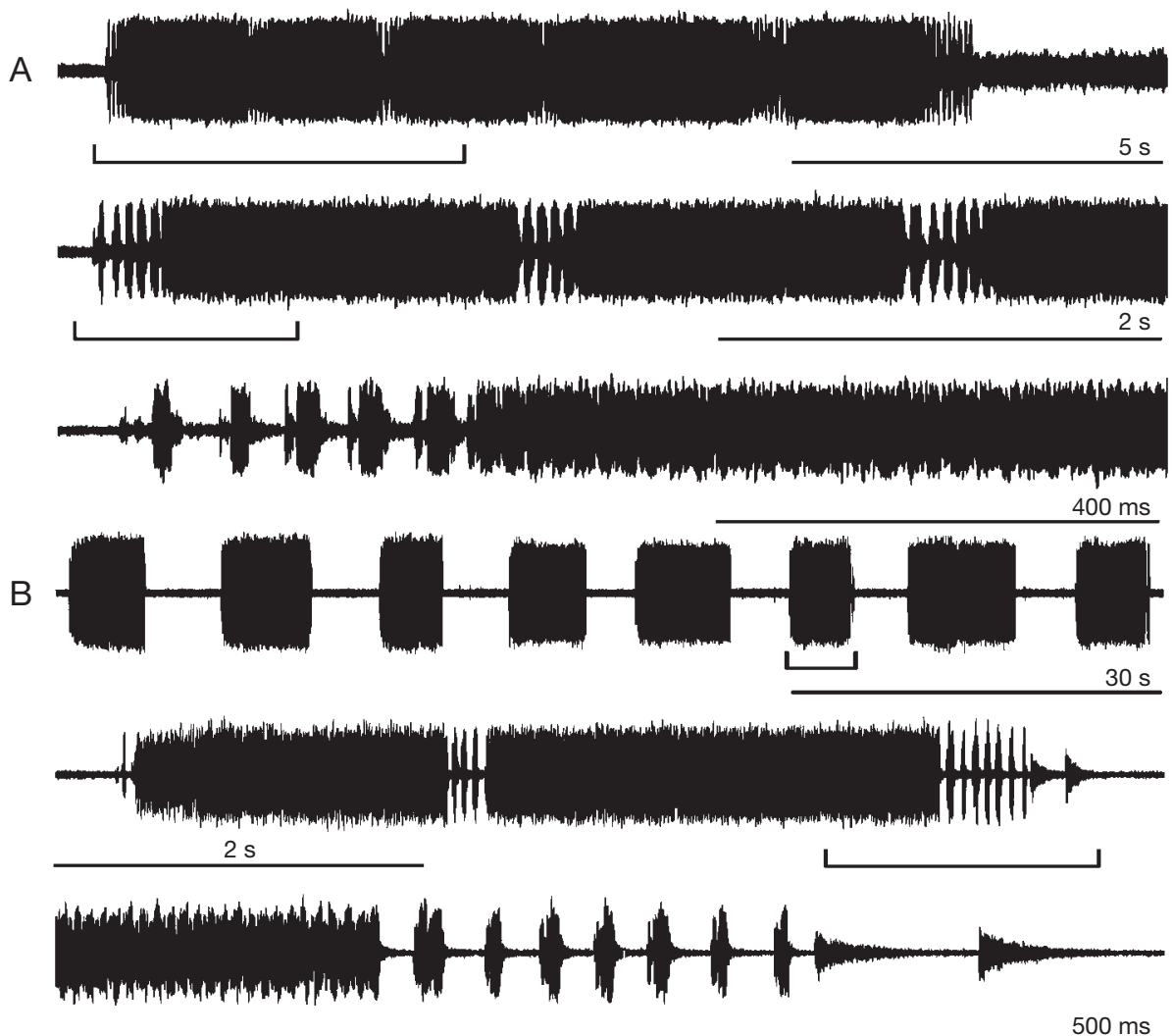

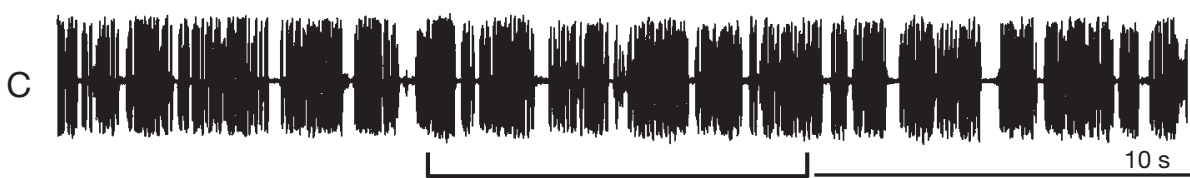
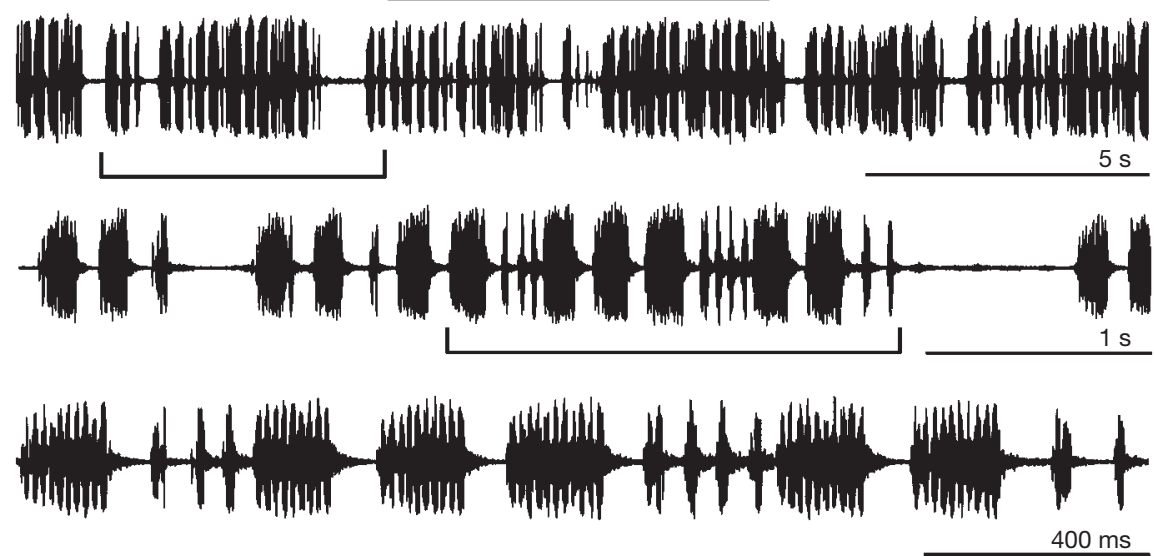

FIG. 17. - Calling song of Conocephalus semivittatus vittatus (Redtenbacher, 1891): A, specimen MNHN-ENSIF2226, $11 \mathrm{H00}, 25^{\circ} \mathrm{C}$, recorded in situ; B, specimen MNHN-ENSIF2224, $12 \mathrm{H} 30,30.6^{\circ} \mathrm{C}$, recorded in situ; C, specimen MNHN-ENSIF2234, $15 \mathrm{H} 00,29^{\circ} \mathrm{C}$, recorded in studio with other male and female specimens. 


\section{Conocephalus laetus (Redtenbacher, 1891)}

Xiphidium laetum Redtenbacher, 1891: 514.

Conocephalus laetus - Karny, 1912: 11. — Pitkin 1980: 345.

Conocephalus dubius Willemse, 1942: 95.

Conocephalus raggei Harz, 1970: 194.

TYPE MATERIAL. - North Australia. 9 holotype (BMNH). Not examined.

Conocephalus dubius: North Australia. ơ holotype (NHMB); 1 allotype (NHMB). Not examined.

Conocephalus raggei: Uganda. o" holotype (BMNH);

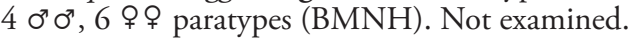

Type LOCAlity. - Australasia, Australia, North Australia.

Distribution. - Widely distributed (Africa, Australia, New Guinea, etc.).

REMARKS

This species has been recorded in Santo by Willemse (1925) in Hog Harbour (clearings) and Chuuri. Neither Pitkin who revised the genus in this world area, nor I have examined these specimens.

\section{Genus Pseudorhynchus Serville, 1838}

Pseudorhynchus lessonii Serville, 1838 (Figs 11E; 15E)

Pseudorhynchus lessonii Serville, 1838: 509. — Kirby 1906: 238. — Bailey 1979: 1027.

Conocephalus roberti Le Guillou, 1841: 294.

Conocephalus alienus Walker, 1869: 324.

Conocephalus extensor Walker, 1869: 329.

Euconocephalus extensor - Karny 1926: 250.

Conocephalus longiceps Redtenbacher, 1891: 412.

Type Material. - Pseudorhynchus lessonii: type lost (Bailey 1979); neotype: Christmas Island, Dr C. A. Gibson-Hill., No 48, 1939-40; NEOTYPE [printed on red and white circular label]; Ex F. M. S., Museum., B. M. 1955-354. [printed]; NEOTYPE, Pseudorhynchus lessonii Serville, det. W. J. Bailey, 1976. [printed], O" $(\mathrm{BMNH})$. Not examined.
Conocephalus roberti: [Pacific, Southwestern Pacific, Samoa] Hamoa et Hapai [sic Le Guillou 1841]. Lost (Bailey 1979).

Conocephalus alienus: Tropical Asia, Malesia, Jawa. O" (BMNH). Not examined.

Conocephalus extensor: [locality unknown], $\odot$ holotype (BMNH). Not examined. In online databases (Eades \& Otte 2009), the holotype is erroneously considered as being a male, and a type locality is given, whereas Walker (1869) states the type locality as unknown and gives ovipositor measurements.

Conocephalus longiceps: New Caledonia. O' syntype (NHW). Not examined.

Type Locality. - Tropical Asia, Malesia, Christmas Island.

Distribution. - Widely distributed in the Pacific. Already known from Espiritu Santo (as Euconocephalus extensor in Willemse 1925).

MATERIAl EXAMined. - Vanuatu. (5 $0^{7} 0^{7}, 7$ 7 ), Sanma Province, Espiritu Santo Isl., Luganville, site du CTRAV, $15^{\circ} 27^{\prime} 00^{\prime \prime}$, $167^{\circ} 12^{\prime} 26^{\prime \prime} \mathrm{E}, 2 \mathrm{~m}$ alt., pelouse, zone herbacée, sur plante, nuit, Exped. Santo 2006, 12.X.2006, coll. S. Hugel, 1 ơ (SH-119), 2 ㅇ $(\mathrm{SH}-127, \mathrm{SH}-128)$ (MNHN-ENSIF2271, 2279, 2280). - Same locality and date, Exped. Santo 2006, coll. T. Robillard, 1 ơ (TR-011 SH-122) (MNHN-ENSIF2274). — Luganville, site du CTRAV, forêt côtière sur sable, $15^{\circ} 27^{\prime} 00^{\prime \prime} S, 167^{\circ} 12^{\prime} 26^{\prime \prime} \mathrm{E}$, $2 \mathrm{~m}$ alt., Exped. Santo 2006, 28.X.2006, coll. S. Hugel, $1 \mathrm{O}^{7}$ (SH-123), 1 ㅇ (SH-125) (MNHN-ENSIF2275, 2277). - Same locality, 29.X.2006, coll. S. Hugel, 1 \% (SH-124) (MNHN-ENSIF2276).

Big Bay, Matantas, Vatthé Conservation area, $15^{\circ} 20^{\prime} \mathrm{S}$, $166^{\circ} 95^{\prime} \mathrm{E}$, nuit, Exped. Santo 2006, 27.X.2006, coll. S. Hugel, 1 \% (SH-120) (MNHN-ENSIF2272). - Same locality and date, herbes hautes en bord de piste, nuit, coll. T. Robillard, $10^{7}$ (TR-397 SH-121) (MNHN-ENSIF2273). — Big Bay, Matantas, Vatthé Conservation area, $15^{\circ} 20^{\prime} \mathrm{S}, 166^{\circ} 95^{\prime} \mathrm{E}$, herbes hautes en bord de piste, nuit, 27.X.2006, coll. S. Hugel, 1 ○ (SH-126) (MNHN-ENSIF2278).

Penaoru, camp de base, ortho5, Exped. Santo 2006, X-XI.2006, coll. E. Boitier, 1 \% (SH-129) (MNHNENSIF2281).

Peavot, cocoteraie, enregistré, Exped. Santo 2006, 23.X.2006, coll. S. Hugel, $10^{7}$ (SH-130) (MNHN-ENSIF2282).

HABITAT AND LIFE HISTORY TRAITS. - We recorded this species in anthropized localities (pasturelands, villages, roadsides) near the shore. Willemse (1925) recorded it from Chuuri 300-600 m and Hog Harbour, open forest.

\section{DESCRIPTION COMPLEMENT}

Stridulatory file (Fig. 11E) with c. 57 lamellar teeth and numerous spinules on both sides of the file (already illustrated by Bailey [1979]). 
Calling SONG (FIG. 15E)

Males call at dusk and during early night hours. The song has been illustrated by Bailey (1979) and a record was published by Rentz (1996). It consists of a long (several minutes) continuous buzz.

\section{Genus Salomona Blanchard, 1853}

\section{Salomona redtenbacheri Brongniart, 1897 (Figs 18-20)}

Salomona redtenbacheri Brongniart, 1897: 159.

Salomona haani Brongniart, 1897: 137, n. syn. (type locality: South western Pacific, Vanuatu).

Salomona magnifica Willemse, 1925: 516, n. syn. (type locality: South western Pacific, Vanuatu).

Type Material. - Mus. Paris, N[ouve]lles Hébrides [Vanuatu], F. von Mueller [coll.], 771-93, Salomona redtenbacheri Brong. Type [all manuscript]. [in alcool]. $0^{7}$ holotype (MNHN-ENSIF1616). Examined.

TyPe LOCAlity. - South western Pacific, Vanuatu.

OTHER MATERIAL EXAMINED. - Type material of S. haani: Mus. Paris, N[ouve]lles Hébrides [Vanuatu]-François [coll.], 189-94, Salomona haani Brong[niart]. Type [all manuscript]. ㅇ (MNHN-ENSIF1614). Examined. Type material of S. magnifica: Jan 8 1923, N Hebrides [Vanuatu], c. $500 \mathrm{ft}$ E.c'st, Esp. Santo I., open forest, nr Hog Harb. dd J.R. Baker, \& Percy Sladen, Mem. Fd. 1923; Santo, 8 Jan 1923 [manuscript]; TYPE o", Willemse, Salamona [sic] magnifica, Tr.Ent.Soc.L., 1925, p.516; Salomona, magnifica nov. sp.[manuscript], Det. C. Willemse; Type [red label]; Salomona ơ redtenbacheri 1923 Bro[n]gn[iart] [manuscript], Det. Uvarov; [1st label IDEM]; TYPE ORTH: 905 2/3, Salomona, magnifica, Willemse's [manuscript], HOPE DEPT. OXFORD [printed]. $\sigma^{\pi}$ holotype (UMO). Examined. - Jan 12 1923, N Hebrides [Vanuatu], 0-100 ft 3m. E. of Esp. Santo I., Elephant I. open forest, dd J.R. Baker, \& Percy Sladen, Mem. Fd. 1923; Santo, 12 Jan 1923 [manuscript]; PARATYPE [female], Willemse, Salamona [sic] magnifica, Tr.Ent.Soc.L., 1925, p.516.; Salomona, magnifica nov. sp. [manuscript], Det. C. Willemse; Cotype [red label]; Salomona redtenbacheri Brogn[iart] Tettigoniidae [manuscript], Det.in B.M., B Uvarov, 1923; Salomona [female] redtenbacheri Brogn[iart] [manuscript], 1923 Det. B Uvarov; [1st label IDEM]; TYPE ORTH : 905 1/3, Salomona, magnifica, Willemse's [manuscript], HOPE DEPT. OXFORD [printed]. $\odot$ allotype (UMO). Examined.
Vanuatu. (5 $0^{7} 0^{7}, 5$ 5 \%), Sanma Province, Espiritu Santo Isl., Penaoru, Ortho6, Exped. Santo 2006, X-XI.2006, 1 ㅇ (SH-149) (MNHN-ENSIF2301).

Luganville, Site du CTRAV, 1527’00”S, 167²'26”E, alt. $2 \mathrm{~m}$, forêt côtière sur sable, Exped. Santo 2006, X.2006, 1 ㅇ (SH-150) (MNHN-ENSIF2302).

Penaoru, camp de base, Ortho12, Exped. Santo 2006, 6.XI.2006, 1 ㅇ (SH-151) (MNHN-ENSIF2303). Penaoru, camp de base, Ortho1, Exped. Santo 2006, 10.XI.2006, 1 O (SH-152) (MNHN-ENSIF2304). Penaoru, 600 m, crottes EB24, Exped. Santo 2006, X-XI.2006, 1 O' (SH-153) (MNHN-ENSIF2305).

Peavot, $14^{\circ} 59^{\prime} 37^{\prime \prime} S$, $166^{\circ} 47^{\prime} 04^{\prime \prime E}, 38 \mathrm{~m}$ alt, forêt secondaire, ancien jardin, rive $S$ de la rivière principale, terrasse haute, nuit, enregistré studio le 25.X.2005, Exped. Santo 2006, 21.X.2006, coll. S. Hugel, $10^{7}$ (SH-154) (MNHN-ENSIF2306). — Peavot, 14'59'37”S, $166^{\circ} 47^{\prime} 04^{\prime \prime} \mathrm{E}, 38 \mathrm{~m}$ alt., forêt secondaire, ancien jardin, rive $S$ de la rivière principale, terrasse haute, nuit, Exped. Santo 2006, 21.X.2006, coll. S. Hugel, 1 (SH-155) (MNHN-ENSIF2307).

Luganville, Site du CTRAV, $15^{\circ} 27^{\prime} 00^{\prime \prime} S, 167^{\circ} 12^{\prime} 26^{\prime \prime} \mathrm{E}$, alt. $2 \mathrm{~m}$, forêt côtière sur sable, enregistré studio, Exped. Santo 2006, 29.X.2006, coll. S. Hugel, 1 O' (SH-156) (MNHN-ENSIF2308).

Peavot, 1459'37'S, 166 47'04”E, $38 \mathrm{~m}$ alt, forêt secondaire, ancien jardin, rive $S$ de la rivière principale, terrasse haute, nuit, Exped. Santo 2006, 20.X.2006, coll. S. Hugel, $10^{7}$ (SH-157) (MNHN-ENSIF2309). — Peavot, $14^{\circ} 59^{\prime} 37^{\prime \prime}$ 'S, 166 47'04"E, $38 \mathrm{~m}$ alt., forêt secondaire, ancien jardin, rive $S$ de la rivière principale, terrasse 3 , sur plante de 3 m, nuit, Exped. Santo 2006, 20.X.2006, coll. S. Hugel, 1 \& (SH-158) (MNHN-ENSIF2310).

Distribution. - South western Pacific, Vanuatu: Ambrym, Elephant Island, Epi, Espiritu Santo, Malekula.

Some of the Salomona solida (Walker, 1869) specimens mentioned in the literature from the Banks (North of Vanuatu) might correspond to this species (see Willemse 1959).

HABITAT AND LIFE HISTORY TRAITS. - We found S. redtenbacheri specimens in both secondarized (abandoned garden) and preserved wooden areas from the coastal areas to up to $600 \mathrm{~m}$. In most of such localities, we detected this species by its loud high pitched song. Adult specimens and particularly males seem preferentially stand on tree tops, and are only seldom observed in lower strata.

Measurements. - See Table 6.

\section{REDESCRIPTION}

Body robust, size medium.

Head (Fig. 18A-E). As wide as or slightly wider than pronotum. Frons and anterior part of genae 
TABLE 6. - Measurements of Salomona redtenbacheri Brongniart, 1897. Abbreviations: see text. Notes: 1, mandibular enlargement level; 2, below the eyes; 3, including S. magnifica Willemse, 1925 type specimens; 4, depends on the preservation.

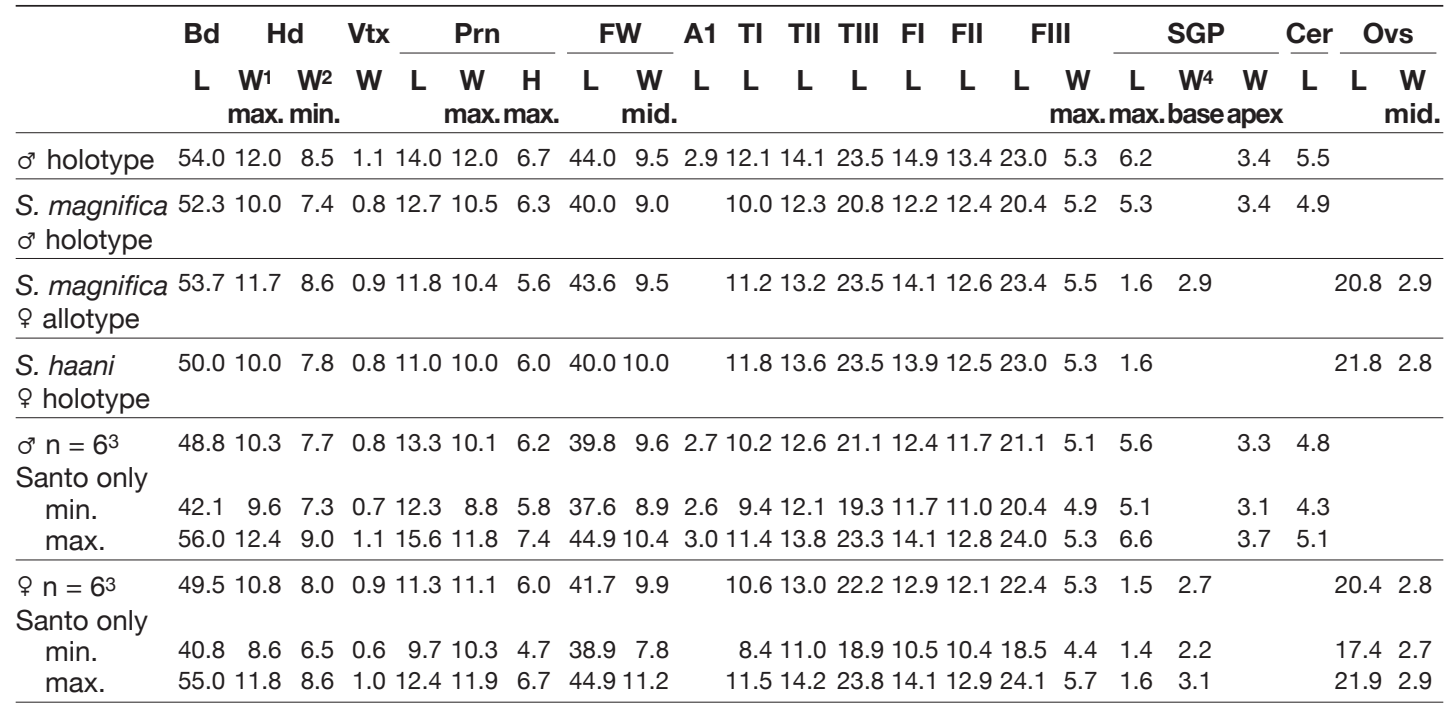

rugosely punctured, forming irregular rugose ridges, without well distinct impressed points. Clypeal area with irregular horizontal wrinkles, clypeal margin subsmooth, supra clypeal area sulci slightly but distinctly impressed on their median edge. Carinae lateralis interna and externa distinct at the ventral base, delimitating a strongly rugose and convex area; superior end of carina lateralis externa (near the ventral external margin of the eye) short, distinctly elevated. Gena posterior part with smooth patches and irregular rugosities, posterior margin subsmooth. Fastigium of the vertex in frontal view: short, exceeding the scrobus superior end, reaching the middle of the scapus, with a median tubercle on the base (on the level of the scrobus ventral margin; the tubercle is variable in size), a short median vertical ridge and connecting the larger fastigium upper part; fastigium apex blunt; in lateral view (Fig. 18E): frontal margin with a concavity (concavity variable: weak or more distinct) near the apex, apex blunt, dorsal margin roundly elevated towards the apex, dorsal base of the vertex with a tubercle (variable in size). Occiput regularly rounded, with weak longitudinal wrinkles. Eyes rounded, moderately projecting. Lateral ocelli weakly distinct on the sides of the fastigium.
Thorax. Pronotum (see also "sexual dimorphism" below); surface rugosely punctured, slightly shiny, with shallowly impressed points particularly on the lateral lobe near the borders; anterior margin regularly arched, strait in dorsal view; with two transverse sulci; anterior transverse sulcus restricted to the discus, shallow, U-shaped, ending near the anterior margin; posterior transverse sulcus deep, ending near the infero anterior lateral lobe margin; discus with a weak but distinct sagittal sulcus; discus and lateral lobe posterior margins hemmed; discus prozona regularly arched, mesozona slightly bulging; metazona different in male and female. Prosternum with a pair of diverging spines, slightly flattened dorsally/ventrally, with sub acute apex; mesosternum lobes with a blunt tubercle on each lateral end of the posterior margin; metasternum with a similar lateral tubercle on each side.

Wings. FW exceeding distinctly the abdominal apex, regularly narrowed towards the apex; 4.2 (min: 3.8; max: 5.0) times as long as wide on the middle; apex rounded.

Legs. TI: with cleft-like similar inner and outer tympana opened dorsally; tympanal area with dorsal paired proximal and distal cuticular invaginations, 

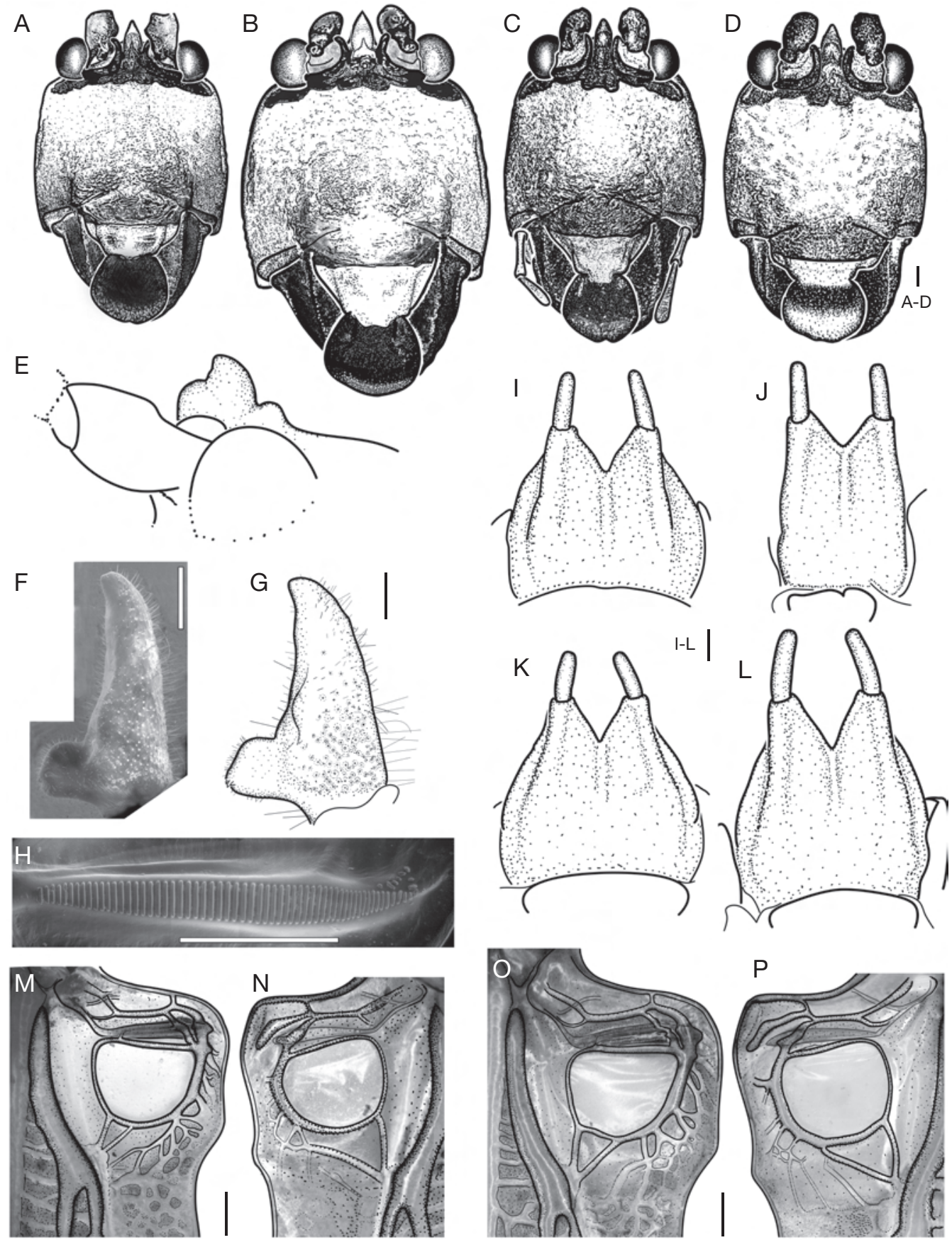

FIG. 18. - Salomona redtenbacheri Brongniart, 1897: A-D face in frontal view; E, fastigium in left lateral view; $\mathbf{F}$, G, left cerci in dorsal view (not exactly the same angle for both); H, SEM picture of the file; I-L, male subgenital plate in ventral view, lateral lobed are visible or not depending on the specimen preservation; $\mathbf{M}, \mathbf{O}$, male left forewing in dorsal view; $\mathbf{N}, \mathbf{P}$, male right forewing in dorsal view. A, K, M, N, specimen MNHN-ENSIF2305 and B, L, O, P, specimen MNHN-ENSIF2304 both from Penaoru, note the strong difference in size; C, G, I, holotype of S. magnifica Willemse, 1925 (UMO); D, J, holotype of S. haani Brongniart, 1897 (MNHN-ENSIF1614); E, holotype of S. redtenbacheri (MNHN-ENSIF1616). Scale bars: $1 \mathrm{~mm}$. 

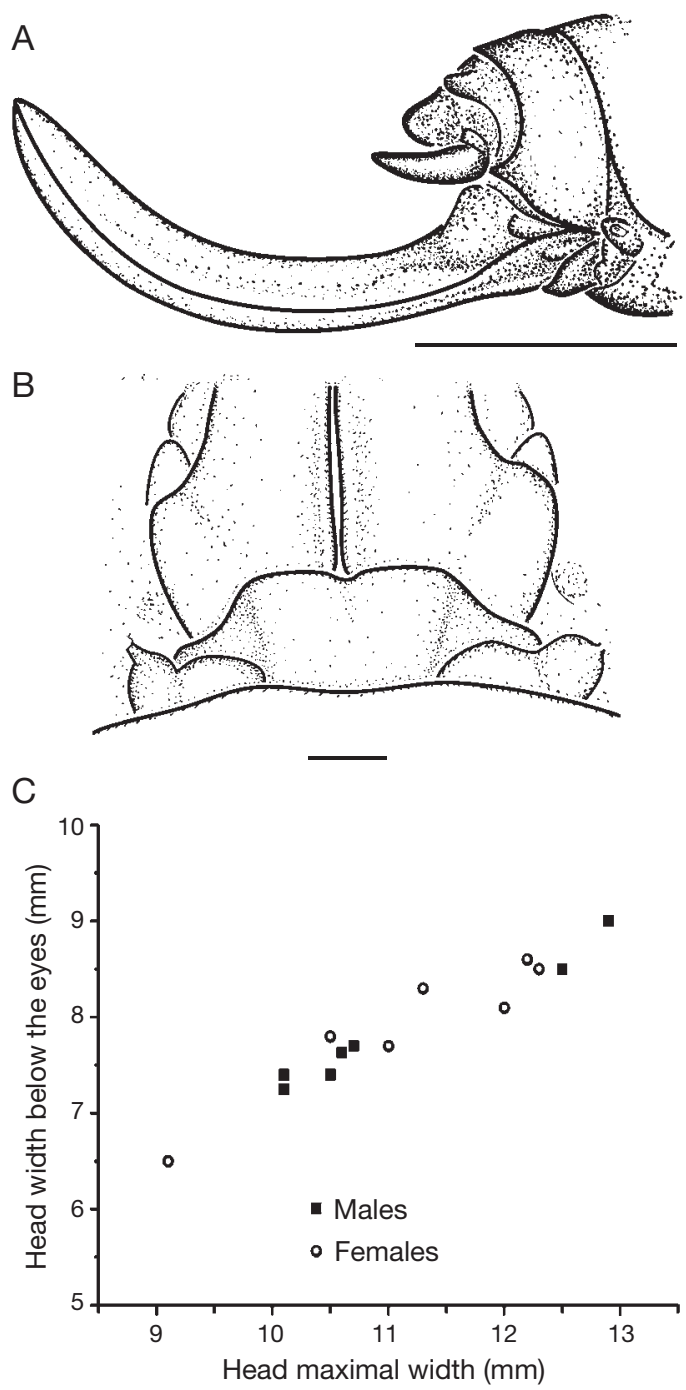

FIG. 19. - Salomona redtenbacheri Brongniart, 1897: A, B, female holotype of S. haani Brongniart, 1897 (MNHN-ENSIF1614); ovipositor in right lateral view (A); subgenital plate in ventral view (B); C, head width below the eyes as a function of head maximal width. Note that although strongly variable, these two parameters are strongly correlated. Scale bars: A, $10 \mathrm{~mm}$; B, $1 \mathrm{~mm}$.

distal invaginations very deep; non tympanal tibial area with dorsal carinae, sub parallel on the apical third, after the apical third, the inner carina approaches the outer dorsal carina (corresponding to head outline position on resting specimens); with distinct inner and outer carinae delimitating a convex ventral area; with 1 inner and 1 outer apical spur; with 5 inner subapical spurs ( 2 on one anomalous leg of specimen SH-156); with 5 outer subapical spurs; without dorsal spurs. FI: knees lateral lobes with 1 apical spine on each side, the inner the longer; laterally flattened; dorsally rounded, without dorsal carina; with distinct ventral carinae delimitating a convex ventral area; with 3-6 (usually 6) inner ventral spines on the inner ventral carina; with 4-7 (usually 5 or 6 ) outer ventral spines on the outer ventral carina. Inner spine on coxa I long and sharp. TII: laterally flattened; dorsally rounded except on the flattened distal end; flattened ventrally; with one ventral apical spur on each side; with 8 or 9 spurs on the ventral anterior margin; with 5-7 spurs on the ventral posterior margin, the proximal the smaller; without dorsal spur. FII rounded dorsally; laterally flattened; knee lateral lobes with one spine on each side, the anterior minute, the posterior longer; with 1 anterior and 1 posterior ventral carina delimitating a flat ventral area; with 4-6 anterior ventral spines; with 1-3 (usually 2) small proximal posterior ventral spines. Anterior dorsal spine on coxa II short, thorn like. TIII with dorsal carinae delimitating a flat dorsal area; with a distinct outer ventral carina; with inner ventral carina on the first distal third; with 2 inner ventral, 2 outer ventral, 1 inner dorsal, 1 outer dorsal apical spurs; with 4-8 (usually 5-7) inner ventral subapical spurs; with 10-14 outer ventral subapical spurs; with 11 or 12 inner dorsal subapical spurs; with 7-10 outer dorsal subapical spurs. FIII: length 4.2 (min: 3.9; max: 4.5) times longer than FIII maximal width (lateral view); with 1 apical spine on each knee lateral lobe; with distinct inner and outer ventral carinae; ventral outer carina with 7-9 spines, the proximal the smaller.

\section{Colour}

The general coloration is variable, from green to brown with or without black elements and darkening on the occiput, the pronotum and the legs. Face coloration relatively stable: brown reddish on the inferior area, of the general body coloration on the superior area; clypeal area black; clypeus white; labrum black except the white apex; top of the face black (on the superior end of carina lateralis externa, 


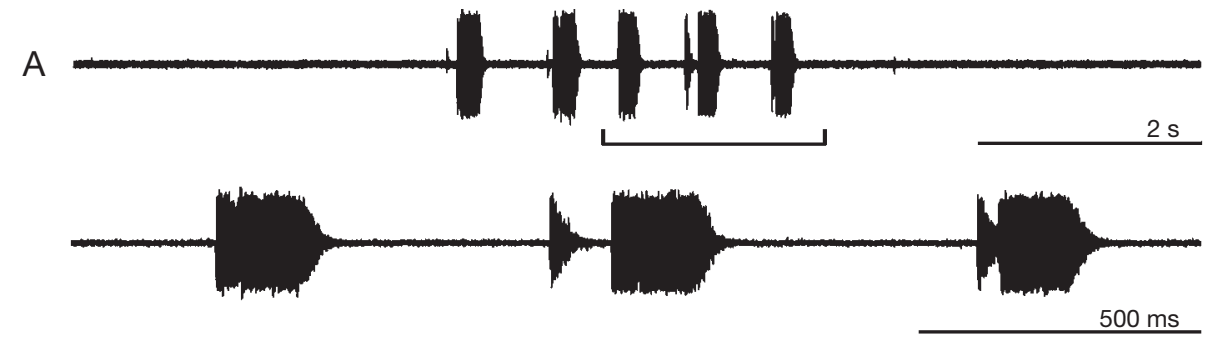

$\mathrm{B}$
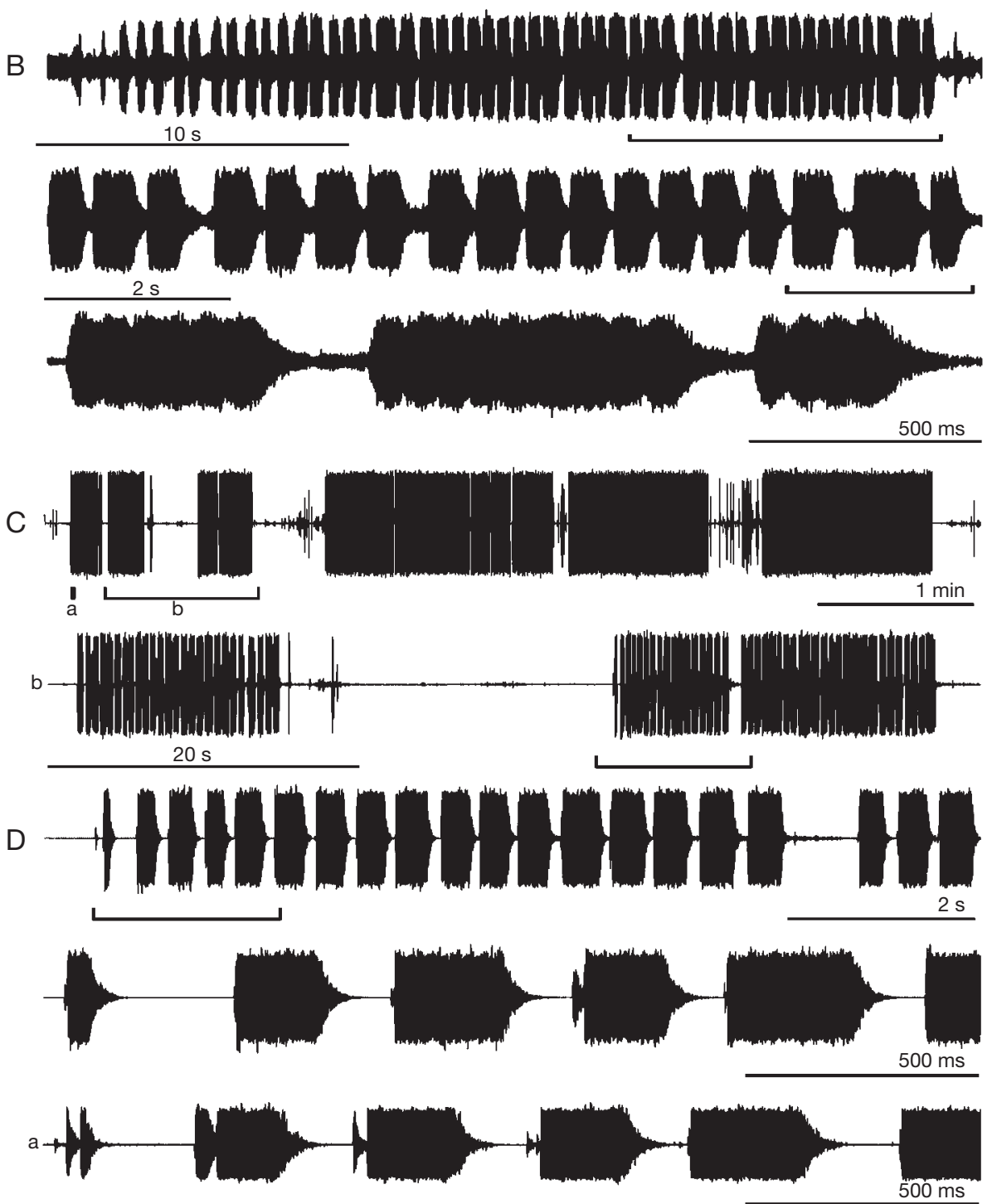

FIG. 20. - Calling song of Salomona redtenbacheri Brongniart, 1897: A, isolated call, studio recording, specimen MNHN-ENSIF2306, $1 \mathrm{H00}, 21^{\circ} \mathrm{C}$; B, specimen not collected, recorded near Butmas, down to the Tankara plateau, $17 . \mathrm{X} .2006,20 \mathrm{H} 30,22^{\circ} \mathrm{C}$; $\mathbf{C}$, studio recording 6.XII.2006, specimen MNHN-ENSIF2308, $22 \mathrm{H} 00,20^{\circ} \mathrm{C}$. 
below the eyes, on the scrobus, on the fastigium, on the scapus); on few specimens, median vertical lines are descending from this superior black area. Eyes surrounded by black. Occiput with more or less extended lateral black bands coming from the eyes posterior margin; wrinkles of darker coloration; sometimes occiput entirely darkened. Pronotum of general body colour (green to brown), with various extent of black patterns (from entirely lacking to shiny black with only the sagittal sulcus lighter). FW veins colour lighter than the general body colour; with darker cells; with weakly defined irregular brown spots. Legs of general body colour, always with black on the tibial knee joint (not visible when legs are extended); specimens with black on the occiput and pronotum usually with darkened/ black legs.

\section{SEXUAL DIMORPHISM}

Body size and wing length similar in males and females. Apart from primary sexual characters, the pronotum discus metazona of both genders is strongly different.

\section{Male}

Pronotum metazona elevated posteriorly, with a transversal step separating the anterior and posterior parts of metazona; metazona covering most of the stridulum; with rounded convex posterior margin; with inconspicuous shallow concavity on the median axis. Singing apparatus: file vein (A1) is well distinct (dorsal view) on the left FW (Fig. 18M, O); file with $59.6 \pm 5.3$ (min: 52; max: 65) lamellar teeth (variation due to the number of small teeth on the inner A1 end, Fig. 18H). Left and right FW tympanum membranous (Fig. 18M-P), well defined, about $0.82 \pm 0.03$ (min: 0.78; max: 0.86) times as long as wide on the right FW. Terminalia: tergite X (last) anterior margin with a median emargination (visible on specimens with extended abdomen) posterior margin widely concave dorsally; epiproct hidden by tergite X. Cerci (Fig. 18F, G) apex pointing anteriorly, blunt; with a shallow dorsal internal protrusion before the middle; with a basal internal protrusion, perpendicular to cerci axis, dorsally/ventrally flattened; with 1-3 apical teeth. SGP (Fig. 18I-L): shape depending on preservation (lateral lobes more or less visible in ventral view); $1.7 \pm 0.1$ (min: 1.6; max: 1.9) times as long as wide on the apex; with a distinct $\mathrm{V}$-shaped posterior emargination $0.21 \pm 0.02$ (min: 0.19; $\max$ : 0.24) times as deep as the maximal SGP length; with distinct lateral carinae, slightly converging towards the apex; with a longitudinal carina distinct on the apex; with distinct styli $1.8 \pm 0.2$ (min: 1.6; max: 2.0) long.

\section{Female}

Pronotum metazona distally flattened, squared, with strait or shallowly concave posterior margin. SGP (Fig. 19B) short; wider than long; convex on the apex. Ovipositor (Fig. 19A) strait on the base and regularly falciform after the base; without denticulations; apex pointing; $7.3 \pm 0.45$ ( $\mathrm{min}$ : 6.5; max: 7.8) times as long (apex to base of the ventral margin) as ovipositor median width.

\section{Calling SONG (FIG. 20)}

Males call during night hours. The song consists either of a short series (sometimes one single, Fig. 20A) of echemes of various lengths, or of echeme-sequences with long trains of echemes of increasing duration (Fig. 20B-D). The echemesequence duration is $41.9 \pm 30.1 \mathrm{~s}$ ( $\mathrm{min}: 7.7$; max: 87.6), and the echeme-sequences are separated by $22.6 \pm 16.6 \mathrm{~s}$ ( $\min : 1$; $\max : 55.5)$. The echeme duration is $379.1 \pm 100.8 \mathrm{~ms}$ (min: 112.6 at the beginning of the train; max: 721.7 at the end of the train). Within echemes, the poorly isolated syllables (Fig. 20B below) are repeated at a rate of $14.8 \pm 0.7 / \mathrm{s}$ (min: 13.4; max: 15.6).

\section{REMARKS}

Three Salomona species have been described from Vanuatu:

- S. haani Brongniart, 1897 described from "Nouvelles Hebrides" [Vanuatu] after a single female. - S. redtenbacheri Brongniart, 1897 described from "Nouvelles Hebrides" [Vanuatu] after a single male. The MNHN collections contain additional Salomona specimens from Vanuatu identified by Willemse as belonging to $S$. redtenbacheri which have been collected in Malekula, Epi and Ambrym. 
- S. magnifica Willemse, 1925 described after one male and one female from Espiritu Santo, and one female from Elephant island. Additional specimens (at least one male; see below) identified as $S$. magnifica are mentioned by the same author from Malekula (Willemse 1959).

Brongniart described the first two Salomona species from Vanuatu in the same work (Brongniart 1897). This author distinguished S. haani and S. redtenbacheri after coloration characters, particularly that of femora (entirely dark in the former, with yellow in the latter). These differences in coloration have been reused in Willemse (1959) key. Willemse (1959) distinguished $S$. redtenbacheri from his new species S. magnifica by the frons width "about as wide at the base as at the eyes" in the former; "broader at the base than at the eyes" in the latter. Nevertheless, Brongniart (1897) states that the frons is almost as wide near the eyes as near the mandibles. In both type specimens, the narrowing of the frons from the mandibles towards the eyes is moderate but distinct and similar.

The 10 Salomona collected during the SANTO 2006 survey display both size and colour variations. The size variation is clear, but no distinct classes can be distinguished in all measured parameters, and all measured parameters are varying together in an isometric way (the genae bulging and face widths as well, Fig. 19C). By contrast, the coloration differences (occiput, pronotum, legs, tegmina), are rather binarious: specimens have either black pattern on pronotum and darkened occiput and legs, or are almost entirely lacking black coloration (except around the eyes, where black surrounding is always present, Fig. 18A-D). All other available morphologic characters are appearing as homogeneous, and apart from coloration and the above-mentioned isometric size variations, males are not distinguishable from $S$. redtenbacheri and S. magnifica male holotypes, and females are not distinguishable from $S$. haani female holotype and S. magnifica female allotype.

The cercus basal inner teeth of $S$. redtenbacheri holotype corresponds to that of $S$. magnifica holotype, and to that of the five specimens collected in Espiritu Santo during the SANTO 2006 survey. In his monography, Willemse (1959) illustrated the ventral view of a non type specimen cercus from Malekula (N.B. in the present article, dorsal views of the cerci are illustrated).

For all the above mentioned reasons, as first reviser (ICZN 1999: article 24.2.2), I consider S. redtenbacheri as a valid species (I prefer to keep as valid the species with a male holotype rather than S. haani having a female holotype), and I consider S. haani and S. magnifica as junior synonyms of S. redtenbacheri.

Genus Phisis Stål, 1861

Phisis Stål, 1861: 324.

TYPE SPECIES. — Listroscelis pectinata Guérin-Méneville, 1831.

\section{Phisis holdhausi Karny, 1926}

(Figs 21A, C; 22)

\section{Phisis holdhausi Karny, 1926: 174.}

TyPe MATERIAL. - Type lost (Jin \& Kevan 1992), type data: Neue Hebrides ex coll. Staudinger. - Neotype data (Jin \& Kevan 1992): New Hebrides, Espiritu Santo, 21-31. VIII.[19]58 [printed]; Borys Malkin, collector, Bishop Museum [printed]; O (BPBM). Not examined. - Neallotype data (Jin \& Kevan 1992): IDEM, 9 (BPBM). Not examined.

Type Locality. - Southwestern Pacific, Vanuatu, Espiritu Santo.

MATERIAL EXAMINED. - Vanuatu. (8 $0^{7} 0^{7}, 4$ 우), Sanma Province, Espiritu Santo Isl., Luganville, site du CTRAV, $15^{\circ} 27^{\prime} 00^{\prime \prime}$ 'S $167^{\circ} 12^{\prime} 26^{\prime \prime} \mathrm{E}, 2 \mathrm{~m}$ alt., forêt côtière sur sable, Exped. Santo 2006, 28.X.2006, coll. S. Hugel, 1 O $^{\prime \prime}$ (SH-141) (MNHN-ENSIF2293). - Same locality and date, sur Terminalia en arrière de plage, coll. S. Hugel, 1 ơ (SH-142) (MNHN-ENSIF2294). - Same locality and date, enregistré, coll. S. Hugel, 1 O' (SH-144) (MNHN-ENSIF2296). - Luganville, site du CTRAV, $15^{\circ} 27^{\prime} 00^{\prime \prime} S, 167^{\circ} 12^{\prime} 26^{\prime \prime E}, 2 \mathrm{~m}$ alt., forêt côtière sur sable, arbre en arrière de plage, Exped. Santo 2006, 29.X.2006,

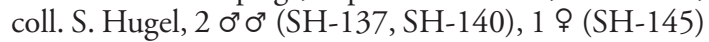
(MNHN-ENSIF2289, 2292, 2297). — Same locality and date, sur Terminalia en arrière de plage, enregistré, coll. S. Hugel, 1 ơ (SH-139) (MNHN-ENSIF2291). Same locality and date, coll. S. Hugel, 1 (SH-146) (MNHN-ENSIF2298). 

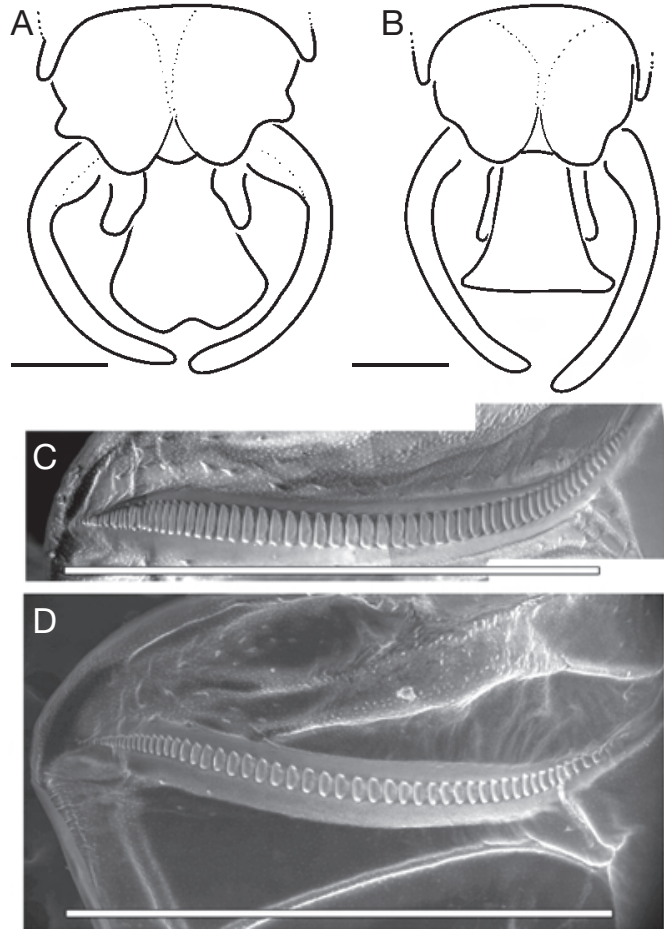

FIG. 21. - Phisis Stål, 1861 species from Espiritu Santo: A, C, P. holdhausi Karny, 1926; B, D, P. pseudopallida Jin \& Kevan, 1992; A, B, male terminalia in dorsal view; C, D, SEM pictures of stridulatory files. Scale bars: $1 \mathrm{~mm}$.

Champagne Beach, sur Terminalia en arrière de plage, jour, Exped. Santo 2006, 28.X.2006, coll. S. Hugel, 2 O" o" (SH-143, SH-138) (MNHN-ENSIF2295, 2290).

Peavot, 1459'37"S, 16647’04”E, 38 m alt., forêt secondaire, ancien jardin, nuit, Exped. Santo 2006, 25.X.2006, coll. S. Hugel, 2 우 (SH-147, SH-148) (MNHN-ENSIF2299, 2300).

Distribution. - Probably the most widespread Phisidini. Widely distributed in the Polynesian/Melanesian area.

HABITAT AND LIFE HISTORY TRAITS. - This species occurs in anthropized areas near and/or on the shore, rarely in slightly more elevated areas. Specimens stay on foliage of large leaves-bearing trees (Terminalia catappa, Barringtonia sp., etc.) and shrubs (Hibiscus sp., etc.). Often several specimens can be observed on the same plant.

\section{DESCRIPTION COMPLEMENT}

Stridulatory file with 64 lamellar teeth and few spinules on both sides of the file (Fig. 21C).
CALling SONG (FIG. 22)

Males call during night. Often, several males are irregularly alternating their call. The call of $P$. holdhausi consists of echemes of irregular length lasting $856.7 \pm 981.4 \mathrm{~ms}$ (min: 3.0; $\max : 4504.9$ ), irregularly separated by $7.494 \pm 22.235 \mathrm{~s}$ (min: 0.038; max: 98.026) long pauses. Within echemes, the syllable rate is $39.2 \pm 1.5 \mathrm{~s}$ (min: 35.6 ; max: 42.4). The principal frequencies of the call are $23-26 \mathrm{kHz}$.

Phisis pseudopallida Jin, 1992 (Fig. 21B, D)

Phisis pseudopallida Jin in Jin \& Kevan 1992: 119.

Type Material. - New Hebrides, Epi Island, Vaemali, 150 m, 9-20.VIII.1967, J. \& M. Sedlack Collectors [all printed], ơ holotype (BPBM); ㅇ allotype (BPBM).

TyPe LOCAliTY. - Southwestern Pacific, Vanuatu, Epi Island.

Material EXAmineD. - Vanuatu. (3 $0^{\circ} 0^{\prime \prime}, 2$ $\%$ ), Sanma Province, Espiritu Santo Isl., Penaoru, camp de base, ortho16, Exped. Santo 2006, 17.XI.2006, 1 o (SH-132), 1 ㅇ (SH-133) (MNHN-ENSIF2284, 2285).

Peavot, $14^{\circ} 59^{\prime} 09^{\prime \prime} S, 166^{\circ} 47^{\prime} 39^{\prime \prime E}$, végétation arbustive en arrière de plage, nuit, Exped. Santo 2006, 24.X.2006, coll. S. Hugel, 1 \% (SH-134) (MNHN-ENSIF2286). - Peavot, $14^{\circ} 59^{\prime} 37^{\prime \prime S}$, $166^{\circ} 47^{\prime} 04^{\prime \prime} \mathrm{E}, 38 \mathrm{~m}$ alt., forêt secondaire, ancien jardin, rive $S$ de la rivière principale, terrasse haute, Exped. Santo 2006, 21.X.2006, coll. S. Hugel, nuit, $10^{7}$ (SH-135) (MNHN-ENSIF2287). — Peavot, $14^{\circ} 59^{\prime} 09^{\prime \prime} \mathrm{S}, 166^{\circ} 47^{\prime} 39^{\prime \prime} \mathrm{E}$, végétation arbustive en arrière de plage, nuit, Exped. Santo 2006, 24.X.2006, coll. S. Hugel, 1 ơ (SH-136) (MNHN-ENSIF2288).

Distribution. - Known from Vanuatu (Epi, Ambrym, Aneityum, Efate, Malekula, Espiritu Santo) and Solomon.

HABITAT AND LIFE HISTORY TRAITS. - We recorded this species often near $P$. holdhausi on trees or shrubs of anthropized areas near the shore. Is seems less widespread than P. holdhausi.

\section{DESCRIPTION COMPLEMENT}

Stridulatory file with 57 lamellar teeth and few spinules on basal and distal file ends anterior sides (Fig. 21D). 

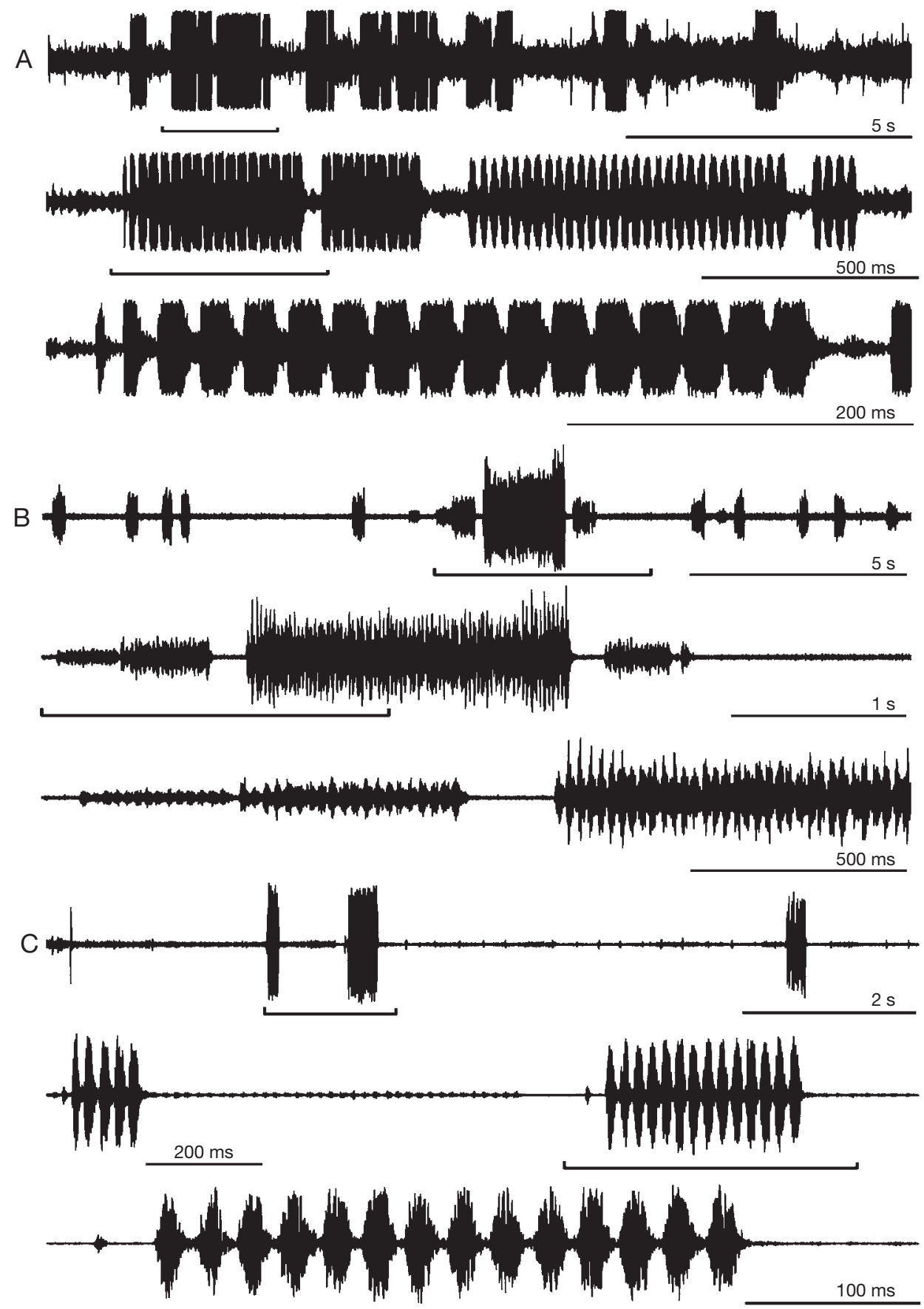

FIG. 22. - Calling of Phisis holdhausi Karny, 1926: A, specimen MNHN-ENSIF2296 recorded in situ; $21^{\circ} \mathrm{C}, 22 \mathrm{H} 00$ (Lebinthus sp. [Eneopterinae crickets] specimens are singing on the ground all around); B, C, specimen MNHN-ENSIF2291 (other specimen responding, not collected) in situ, $21^{\circ} \mathrm{C}, 22 \mathrm{HOO}$. 


\section{TAXA MENTIONED AS OCCURRING IN NEIGHBOURING ISLANDS AND NOT OBSERVED IN SANTO}

Some species are lacking in our samples and might occur in Espiritu Santo: the Phisidini Biproctis anatomensis Jin, 1992, described after five specimens collected in Aneityum (south of the archipelago); Segestidea leefmansi (Willemse, 1940) is mentioned in Orthoptera species files (Eades \& Otte 2009) from Vanuatu, but this type locality data is erroneous, the holotype of $S$. leefmansi is from Papua New Guinea, New Hanover, Lavongai; Paragryllacris combusta (Gerstaecker, 1860) is mentioned from Vanuatu by Karny (1930a, 1937).

\section{GIVEN NAMES IN ESPIRITU SANTO}

Habitants of Peavot (E Cumberland) do well recognize and name the different tettigonioids occurring in and around the village in their Piamatsina language. The green bush crickets (Conocephalus, Pseudorhynchus and Ityocephala) are called Tsicho [tsit $\int \mathrm{o}$ ]; Salomona redtenbacheri is named Nasho [na $\left.\int \mathrm{o}\right]$; gryllacridids are called Tchancha [t $\left.\int \mathrm{an} \int \mathrm{a}\right]$. The giant stick insect Hermarcus inermis is called Saisa [saisa].

\section{Acknowledgements}

The SANTO 2006 Expedition was organized by Muséum national d'Histoire naturelle, Paris, Pro Natura International (PNI), and Institut de Recherche pour le Développement (IRD). It operated under a permit granted to Philippe Bouchet (MNHN) by the Environment Unit of the Government of Vanuatu. Within the expedition, the entomologists operated under the "Forests, Mountains, Rivers" theme coordinated by Bruno Corbara, Philippe Keith and Jérôme Munzinger, and field work for Orthoptera was specifically conducted in collaboration with Laure Desutter-Grandcolas and Tony Robillard. An additional grant from the PPF "État et structure phylogénétique de la biodiversité actuelle et fossile”, MNHN, is also acknowledged here. We thank Simon Poulain for his help in the preparation of the specimens from SANTO 2006. We thank James Hogan (Hope Entomological Collections, UMO) and Kai Schütte (ZMUH) for the loan of specimens; Susanne Randolf and Franziska Anderle (NHW), and Bert Gustafsson (NHRS) for the numerous high quality type specimens pictures; David Nickle for his examination of Furnia from Fiji. We thank Jean-Hervé Lignot (Institut Pluridisciplinaire Hubert Curien, DEPE, UMR 7168, Strasbourg) for the use of the environmental scan electron microscope. We thank our friends and colleagues having participated to SANTO 2006 survey and the Ni-Vanuatu people, for their friendliness, their hospitability and their help in the field.

\section{REFERENCES}

BAILEY W. J. 1979. — A review of Australian Copiphorini (Orthoptera: Tettigoniidae: Conocephalinae). Australian Journal of Zoology 27: 1015-1049.

BlanCHARD E. 1845. - Histoire Naturelle des Insectes. Tome II. Librairie F. Savy, Paris, 544 p.

Bolívar I. 1903. - Contributions à l'étude des Mecopodinae. Annales Historico-Naturales Musei Nationalis Hungarici, Pars Zoologica 1: 161-178.

Bouchet P., Le Guyader H. \& Pascal O. 2008. Des voyages de Cook à l'expédition Santo 2006: un renouveau des explorations naturalistes des îles du Pacifique. Journal de la Société des Océanistes 126-127: 167-185.

Bouchet P., Le Guyader H. \& Pascal O. (eds) in press. - The Natural History of Santo. Patrimoines Naturels.

Brongniart C. 1897. - Revision des Salomonitae; Locustidae de la tribu des Conocephalinae. Bulletin de la Société philomatique de Paris (8) 8: 120-212 (dated 1896, published 1897).

BRUNER L. 1916. - Notes on the orthopteroid insects of the Fiji Islands. Proceedings of the Hawaiian Entomological Society 3: 148-168.

BRUNNER VON WATTENWYL C. 1888. — Monographie der Stenopelmatiden und Gryllacriden. Verhandlungen der Zoologisch-Botanischen Gesellschaft Wien 38: 247-394.

Burmeister H. 1838. - Handbuch der Entomologie, Zweiter Band. Besondere Entomologie. Zweite Abtheilung Kaukerfe, Gymnognatha. Erste Hälfte; vulgo Orthoptera. T.C.F. Enslin, Berlin, 299 p.

Caudell A. N. 1916. — Orthoptera, Fam. Locustidae, Subfam. Mecopodinae, in WYTSMAN P. (ed.), Genera Insectorum. 171. V. Verteneuil \& L. Desmet, Bruxelles: $1-32$. 
Caudell A. N. 1927. - Report on the orthopteroid insects collected by the Fiji-New Zealand Expedition from the University of Iowa. University of Iowa Studies in Natural History 12: 1-22.

Desutter-Grandcolas L. 2003. - Phylogeny and the evolution of acoustic communication in extant Ensifera (Insecta, Orthoptera). Zoologica Scripta 32: 525-561.

DiRsH V. M. 1965. - The African Genera of Acridoidea. Anti-Locust Research Centre, London; Cambridge University Press, Cambridge, 579 p.

Eades D. C. \& OtTe D. 2009. - Orthoptera Species File Online. Version 2.0/3.5. [24.I.2009]. http:// orthoptera.speciesfile.org.

GrIFFINI A. 1909. — Studi sopra alcuni Grillacridi del Museo Nazionale di Budapest. Annales HistoricoNaturales Musei Nationalis Hungarici, Pars Zoologica 7: 307-336.

GrifFINI A. 1911. - Studii sui Grillacridi del Museo Civico di Storia Naturale di Genova. Annali del Museo Civico di Storia Naturale "Giacomo Doria", Genova (3) 5: 79-140.

GRIFFINI A. 1913. - Descrizioni di alcune Gryllacris nuove o poco note del Museo Nazionale di Budapest. Annales Musei Nationalis hungarici 11: 286-304.

Hebard M. 1922. - Studies in Malayan, Melanesian and Australian Tettigoniidae (Orthoptera). Proceedings of the Academy of Natural Sciences of Philadelphia 74: 121-299.

ICZN 1999. - International Code of Zoological Nomenclature. The International Trust for Zoological Nomenclature, London, $406 \mathrm{p}$.

Jin X.-B. \& Kevan D. K. McE. 1992. - Taxonomic revision and phylogeny of the tribe Phisidini (Insecta: Grylloptera: Meconematidae). Theses Zoologicae 18. Koeltz Scientific Books, Koenigstein, 360 p.

KaLTENBACH A. 1968. — Ergebnisse der Österreichischen Neukaledonien-Expedition 1965. Neue und wenig bekannte Orthopteren aus Neukaledonien. I. Mantodea, Saltatoria (exclus. Gryllodea) und Dermaptera. Annalen des Naturhistorischen Museums in Wien 72: 539-556.

KaRnY H. H. 1907. - Revisio Conocephalidarum. Abhandlungen der zoologisch-botanischen Gesellschaft Wien 4: 1-114.

KARNY H. H. 1912. — Orthoptera Fam. Locustidae Subfam. Copiphorinae, in WYTSMAN P. (eds), Genera Insectorum 139. V. Verteneuil \& L. Desmet, Bruxelles: 1-50.

KaRnY H. H. 1926. - Beiträge zur malayischen Orthopterenfauna XV. Die Conocephalinen (s.l.) des Buitenzorger Museums. Treubia 9: 162-254.

Karny H. H. 1925. - Fauna Buruana. Orthoptera, Fam. Gryllacridae. Treubia 7: 41-84.

Karny H. H. 1928. - Ueber die Gryllacriden der Deutschen Kaiserin Augustafluß-Expedition 1913. Mitteilungen aus dem Zoologischen Museum, Berlin
14: 83-114.

KARNY H. H. 1930a. - On the geographical distribution of the Pacific Gryllacridids. Proceedings of the Fourth Pacific Science Congress Java, 1929, Batavia-Bandoeng 3: $157-170$.

Karny H. H. 1930b. - Die Gryllacriden von NeuGuinea. 3. Die Bearbeitung der Ausbeute Docters van Leeuwen. Nova Guinea 15: 361-406.

KARNY H. H. 1931. - Orthoptera Celebica Sarasiniana. I. Saltatoria, Fam. Tettigoniidae \& Gryllacrididae. Treubia 12, suppl.: 1-184.

KarNy H. H. 1932. — Die Gryllacrididen des Pariser Museums und der Collection L. Chopard. Eos. Revista Española de Entomologia 8: 235-309.

KARNY H. H. 1935. - Über einige neue und wenig bekannte Gryllacridinen. Sbornik Entomologichecho Oddeleni Naroduicho Musea v Praze (Acta Entomologica Musea Prague) 13: 31-52.

KARNY H. H. 1937. - Orthoptera Fam. Gryllacrididae Subfamiliae omnes, in WyTSMAN P. (eds), Genera Insectorum. V. Verteneuil \& L. Desmet, Bruxelles: 1-317.

KIRBY W. F. 1906. - A Synonymic Catalogue of Orthoptera. Vol. II. Orthoptera Saltatoria. Part I. (Achetidae et Phasgonuridae). The Trustees of the British Museum, London, $562 \mathrm{p}$.

Lawrence J. F., Nielsen E. S. \& Mackerras I. M. 1991. - Skeletal anatomy and key to orders, in NAUMANN I. D. \& CARNE P. B. (eds), The Insects of Australia. Melbourne University Press, Carlton: 3-32.

LE Guillou E. J. F. 1841. — Description de 23 espèces nouvelles d'Orthoptères, recueillies pendant son voyage autour du monde sur La Zelée. Revue zoologique par la Société cuvierienne 4: 291-295.

Отте D. 2000. - Orthoptera Species File 8. Gryllacrididae, Stenopelmatidae, Cooloolidae, Schizodactylidae, Anastostomatidae and Rhaphidophoridae. Orthopterists' Society at the Academy of Natural Sciences of Philadelphia, Philadelphia, $97 \mathrm{p}$.

PITKIN L. M. 1980. - A revision of the Pacific species of Conocephalus Thunberg (Orthoptera: Tettigoniidae). Bulletin of the British Museum (Natural History), Entomology Series 41: 315-355.

RagGe D. R. 1956. - A revision of the genera Phaneroptera Serville and Nephoptera Uvarov (Orthoptera: Tettigoniidae), with conclusions of zoogeographical and evolutionary interest. Proceedings of the Zoological Society of London 127: 205-283.

RagGe D. R. \& ReYNOLDS W. J. 1998. - The Songs of the Grasshoppers and Crickets of Western Europe. Harley Books, Colchester, Essex, 591 p.

RedtenbaCHer J. 1891. - Monographie der Conocephaliden. Verhandlungen der Zoologisch-Botanischen Gesellschaft Wien 41: 315-562.

REDTENBACHER J. 1892. - Monographische Uebersicht der Mecopodiden. Verhandlungen der Zoologisch-Botanischen 
Gesellschaft Wien 42: 183-224.

RENTZ D. C. F. 1996. - Grasshopper Country. The Abundant Orthopteroid Insects of Australia. Orthoptera; Grasshoppers, Katydids, Crickets. Blattodea; Cockroaches. Mantodea; Mantids. Phasmatodea; Stick Insects. University of New South Wales, Sydney, 284 p.

SerVILle J. G. A. 1838. - Histoire naturelle des Insectes. Orthoptères. Librairie Encyclopédique de Roret, Paris, $776 \mathrm{p}$.

STÅL C. 1861. - Orthoptera species novas descripsit, in Kongliga Svenska Fregatten Eugenies Resa, Omkring Jorden under befal af C.A. Virgin, aren 1851-1853, Vetenskapliga Lakttagelser Pa H. M. Konung Oscar der Forstes Befallning, vol. 2, Zoologi. 1. Insecta. P. A. Norstedt and Soner, Stockholm: 299-350.

STÅL C. 1876. - Observations orthoptérologiques. 2. Bihang till Kongliga Svenska Vetenskaps-akademiens Handlingar 4 (5): 1-58.

Tepper J. G. O. 1892. — The Gryllacridae and Stenopelmatidae of Australia and Polynesia. Transactions of the
Royal Society of South Australia 15: 137-178.

THUNBERG C. P. 1815. - Hemipterorum maxillosorum genera illustrata plurimisque novis speciebus ditata ac descripta. Mémoires de l'Académie impériale des Sciences de St. Pétersbourg 5: 211-301.

WaLKer F. 1869. - Catalogue of the Specimens of Dermaptera Saltatoria and Supplement to the Blattariae in the Collection of the British Museum. Pt 1. British Museum of Natural History, London, 224 p.

WALKER F. 1871. - Supplement to the Catalogue of Dermaptera Saltatoria. British Museum of Natural History, London, $116 \mathrm{p}$.

Willemse C. 1925. - Contribution à la faune des Orthoptères des Nouvelles-Hébrides. Transactions of the Royal Entomological Society of London: 513-529.

Willemse C. 1959. - Notes on the genus Salomona Blanchard (Orthoptera, Tettigonioidea, subfam. Agraecinae). Publicaties van het Natuurhistorisch Genootschap in Limburg 11: 1-118 (dated 1958-1959, published 1959). 